
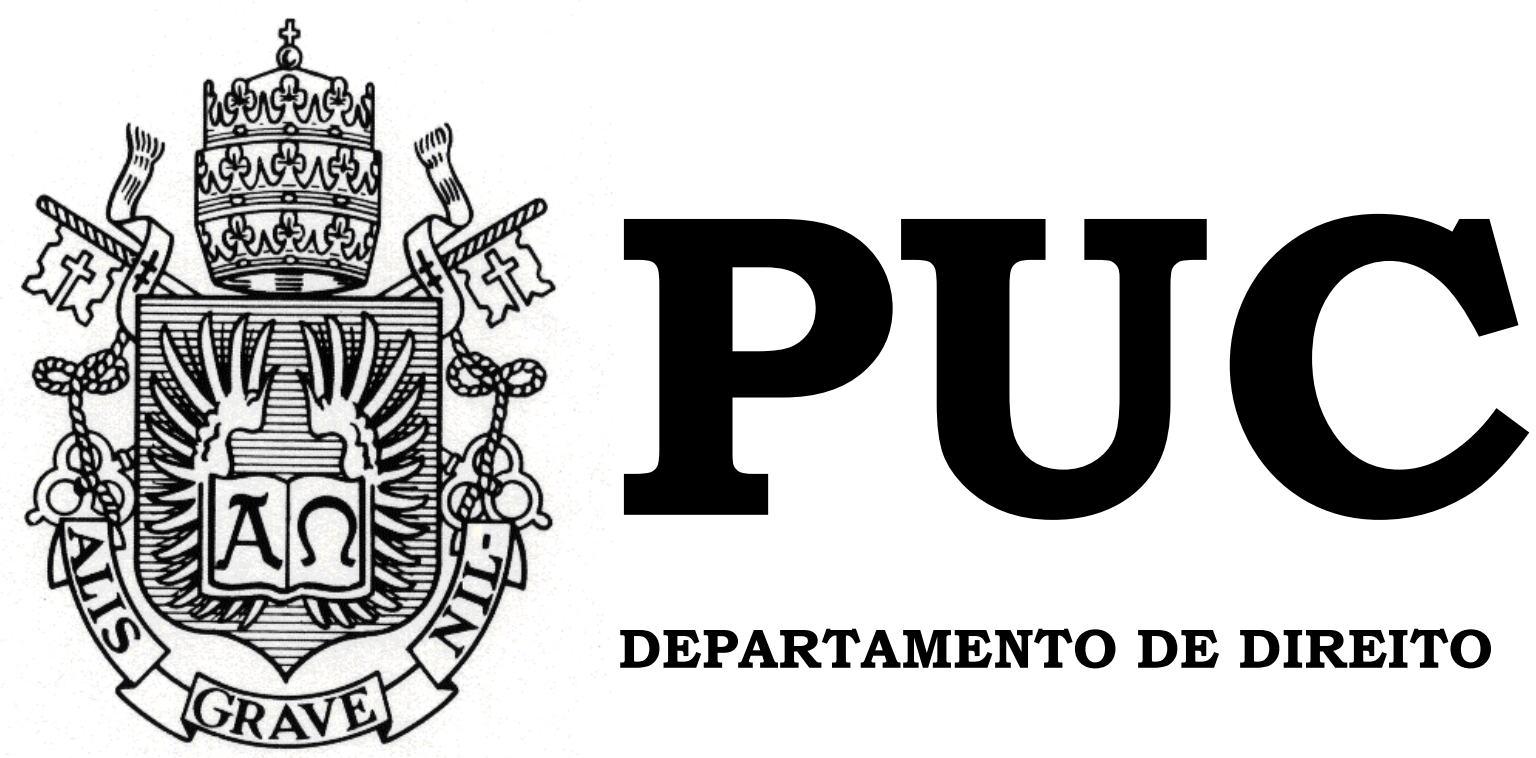

DEPARTAMENTO DE DIREITO

\title{
A DIFICULDADE DE SER “AUTÔNOMO" NO BRASIL
}

Por

CAROLINE SEREJO CYPRIANO

ORIENTADOR: FRANCISCO MÜSSNICH

2017.1

PONTIFÍCIA UNIVERSIDADE CATÓLICA DO RIO DE JANEIRO RUA MARQUÊS DE SÃO VICENTE, 225 - CEP 22451-900

RIO DE JANEIRO - BRASIL 


\title{
A DIFICULDADE DE SER "AUTÔNOMO" NO BRASIL
}

por

\section{Caroline Serejo Cypriano}

\author{
Monografia apresentada ao \\ Departamento de Direito da \\ Pontificia Universidade Católica do \\ Rio de Janeiro (PUC-Rio) para a \\ obtenção do Título de Bacharel em \\ Direito.
}

Orientador: Francisco Müssnich 


\section{DEDICATÓRIA}

Dedico esta Monografia, em primeiro lugar, à Deus e à minha família, pelo incomensurável amor a mim destinado. À minha mãe que deu asas aos meus sonhos e sempre se sacrificou por mim; ao meu pai pela imensa sabedoria que divide comigo todos os dias e por me proporcionar o melhor; ao meu irmão por me apoiar e tirar minhas dúvidas a todo o momento, tanto jurídicas quanto de vida, além de rever partes desta Monografia; à minha irmã pela proatividade costumeira (que inclusive se prontificou a formatar este trabalho); ao meu avô que me ajudou sempre que precisei; e à minha avó que está no céu me abençoando.

Agradeço ainda imensamente ao meu orientador e professor Francisco Müssnich - que gentilmente aceitou que eu mudasse meu tema inicial de comparação de sociedades limitadas e sociedades anônimas com estruturas societárias americanas para esse meu tema improvável - por suas aulas dinâmicas, indicações bibliográficas e por ser para mim um exemplo por seu profundo conhecimento de direito societário, mas acima de tudo por seu admirável raciocínio estratégico. Devo ainda agradecimento ao meu professor Paulo Penna, pelos incontáveis e excelentes esclarecimentos e indicações de bibliografia.

Em terceiro lugar, agradeço aos meus amigos, por aturarem meu desespero de acreditar que não finalizaria minha Monografia no prazo e àqueles que entenderam a minha ausência aos seus aniversários porque eu estava escrevendo este trabalho.

Por fim, mas não menos importante, a cada pequeno empresário que sonha em um dia ter um grande negócio e ao Brasil, que um dia o Brasil não seja apenas um sonho intenso de quem trabalha por uma vida melhor e que não apenas o futuro espelhe grandeza, mas o presente. 


\section{RESUMO}

CYPRIANO, Caroline Serejo. A Dificuldade de Ser “Autônomo" no Brasil. Rio de Janeiro: 2017: 85 p. Monografia de final de curso. Departamento de Direito da Pontifícia Universidade Católica do Rio de Janeiro - PUC-Rio.

Ter um negócio no Brasil, de modo geral, não é simples - em grande medida devido à legislação desfavorável ou de exigências desnecessárias e é ainda mais árduo para os "Autônomos" que precisam lidar com os percalços 'sozinhos'. Esses são aqui definidos por Empresários Individuais, Microempreendedores Individuais e Empresas Individuais de Responsabilidade Limitada - englobando, ainda, em certa medida, as Microempresas e Empresas de Pequeno Porte - tão relevantes para a economia brasileira, porém pouco tratados em doutrina. Essa monografia se propõe, então, a criticar questões da legislação, por um viés jurídicopragmático, que são prejudiciais a esses empresários e, portanto, à economia brasileira.

Palavras-Chave: Direito Privado. Direito Empresarial. Direito Tributário. Regimes Tributários. Custo Brasil. Simples Nacional. Burocracia. Empresa. Empresário. Microempresa. Microempreendedor. Empresário Individual. Empresa Individual de Responsabilidade Limitada. Microempresa. Empresa de Pequeno Porte. EI. MEI. EIRELI. ME. EPP. 


\section{SUMÁRIO}

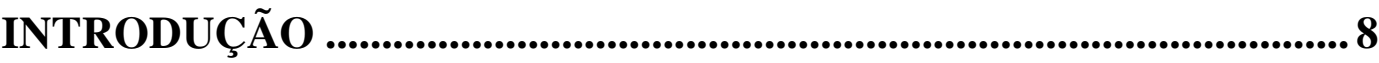

CAPÍTULO 1 - DEFINIÇÃO DE AUTÔNOMO.........................................17

1.1. Da Natureza Empresária .................................................................. 17

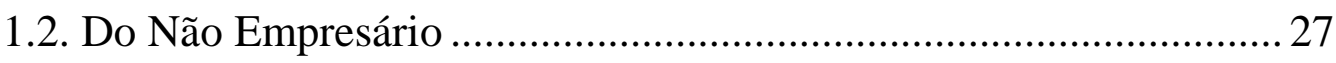

CAPÍTULO 2 - EMPRESÁRIO INDIVIDUAL .........................................34

2.1. O Porquê da Existência do EI............................................................ 34

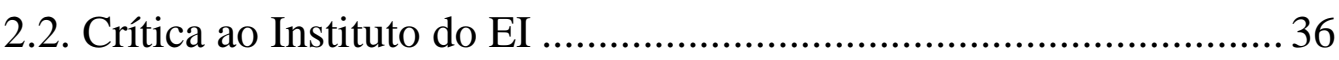

CAPÍTULO 3 - MICROEMPREENDEDOR INDIVIDUAL ................. 41

3.1. O Porquê da Existência do MEI ......................................................... 41

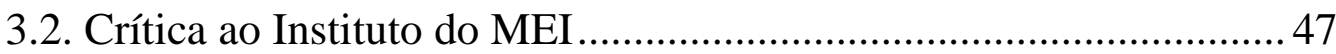

CAPÍTULO 4 - EMPRESA INDIVIDUAL DE RESPONSABILIDADE

LIMITADA .................................................................................................................... 56

4.1. O Porquê da Existência da EIRELI ................................................ 56

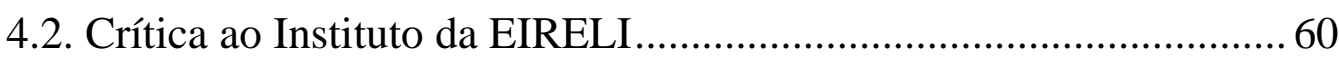

CAPÍTULO 5 - MICROEMPRESA E EMPRESA DE PEQUENO

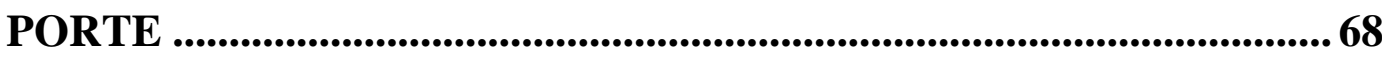

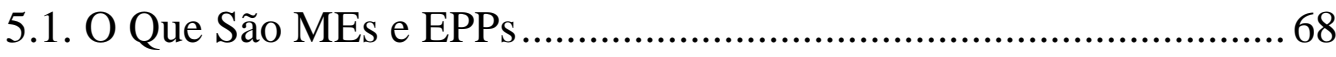

5.2. Crítica aos Institutos da ME e EPP................................................... 71

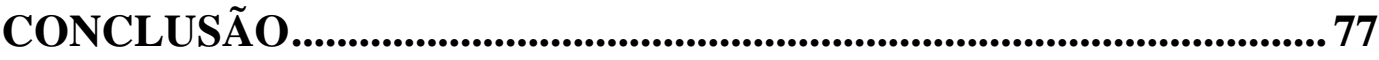

REFERÊNCIAS BIBLIOGRÁFICAS ........................................................ 80 


\section{LISTA DE FIGURAS}

Figura 1 - Ranking das Juntas Comerciais segundo Movimento de Constituição, Alteração e Extinção de Empresas ............................................... 11

Figura 2 - Custo Brasil Ilustrado ............................................................................. 12

Figura 3 - Questão 4 da Pesquisa de Mercado 'Negócios\&Etc' .................... 14

Figura 4 - Questão 5 da Pesquisa de Mercado 'Negócios\&Etc' .................... 14

Figura 5 - Valor adicionado das Micro e Pequenas Empresas na Economia Nacional 2009 a 2011 ............................................................................................... 15 


\title{
LISTA DE ABREVIAÇÕES
}

\author{
ADI - Ação Direta de Inconstitucionalidade \\ Art. - Artigo \\ CC - Código Civil \\ CEE - Comunidade Econômica Europeia \\ CF - Constituição Federal \\ CGSIM - Comitê de Gestão da Redesim \\ CGSN - Comitê Gestor do Simples Nacional \\ CJF - Conselho da Justiça Federal \\ CNPJ - Cadastro Nacional de Pessoas Jurídicas \\ COFINS - Contribuição para o Financiamento da Seguridade Social \\ CPP - Contribuição Previdenciário Patronal \\ CSLL - Contribuição Sobre Lucro Líquido \\ DASN-SIMEI - Declaração Anual do Simples Nacional para o \\ Microempreendedor Individual \\ DREI - Departamento de Registro Empresarial e Integração \\ EI - Empreendedor Individual \\ EIRELI - Empresa Individual de Responsabilidade Limitada \\ EPP - Empresa de Pequeno Porte \\ ICMS - Imposto de Circulação Sobre Mercadoria e Serviços \\ INSS - Instituto Nacional de Seguridade Social \\ IOF - Imposto Sobre Operações Financeiras \\ IPI - Imposto Sobre Produtos Industrializados
}


IR - Imposto de Renda

IRPF - Imposto de Renda Pessoa Física

IRPJ - Imposto de Renda Pessoa Jurídica

ISS - Imposto Sobre Serviço

JUCEES - Junta Comercial do Estado do Espírito Santo

LC - Lei Complementar

ME - Microempresa

MEI - Microempreendedor Individual

NF-e - Nota Fiscal Eletrônica

PIB - Produto Interno Bruto

PIS - Programa de Integração Social

PL - Projeto de Lei

PUC-SP - Pontifícia Universidade Católica - São Paulo

RFB - República Federativa do Brasil

SEBRAE - Serviço Brasileiro de Apoio às Micro e Pequenas Empresas 


\section{INTRODUÇÃO}

As dificuldades enfrentadas por empreendedores no Brasil compõem uma temática de larga extensão, que tomaria um livro de vários volumes, e, infelizmente, a brevidade do tempo para se elaborar uma tese de graduação leva este trabalho a selecionar tópicos e tecer breves críticas a dispositivos legais e métodos de aplicação prática em um âmbito jurídico em muito negligenciado por doutrinadores: a realidade dos pequenos empresários (em termo leigo) que desempenham individual e isoladamente atividades econômicas, aqueles que chamo aqui de Autônomos. Neste capítulo me proponho a expor a relevância econômica da temática e daí extrair sua relevância jurídica e nos capítulos seguintes propor uma análise efetivamente jurídica de tópicos da matéria. É importante ressaltar que não se trata de uma avaliação comparativa em relação a outros países, mas uma reflexão interna por melhoramentos.

Começo por explicar que a minha opção por uma contextualização econômica da relevância do tema surge de uma influência da escola de Law and Economics, da Universidade de Chicago, fundada por Richard A. Posner, uma vez que acredito que toda a lei deve pressupor uma análise consequencialista dos impactos que gerará na economia, pois não é possível ignorar que estamos inseridos em um sistema capitalista, e para tanto, sem recursos nada é passível de ser feito. Razão esta que me faz crer que toda a escola de direito deveria ter um núcleo de análises econômicas da lei, o que infelizmente não faz parte da realidade brasileira. Diante disso, digo ainda que o estudo do direito alinhado à economia seria essencial para influenciar a criação ou alteração de leis de forma mais técnica e consciente, o que me leva a citar um trecho de artigo "Values and Consequences: An Introduction to Economic Analysis of Law", escrito por Posner:

The economic analysis of law, as it now exists not only in the United States but also in Europe, which has its own flourishing law and economics association, has both positive (that is, descriptive) and normative aspects. It tries to explain and 
predict the behavior of participants in and persons regulated by the law. It also tries to improve law by pointing out respects in which existing or proposed laws have unintended or undesirable consequences, whether on economic efficiency, or the distribution of income and wealth, or other values. It is not merely an ivory-towered enterprise, at least in the United States, where the law and economics movement is understood to have influenced legal reform in a number of important areas. These areas include antitrust, the regulation of public utilities and common carriers, environmental regulation, the computation of damages in personal injury suits, the regulation of the securities markets, the federal sentencing guidelines, the division of property and the calculation of alimony in divorce cases, and the law governing investment by pension funds and other trustees, and to have been a significant factor in the deregulation movement and in free-market ideology generally. Most major and many minor law schools have one or two full-time economists on their faculty; a number of law professors have Ph.D.'s in economics; there are six scholarly journals devoted to economic analysis of law, with a seventh on the way; the use of economists as expert witnesses has become conventional in a range of important fields; judicial opinions refer to economic concepts and cite economic books and articles; and a number of federal judges, including a Justice of the Supreme Court (Stephen Breyer), are alumni of the law and economics movement. Economic analysis of law is generally considered the most significant development in legal thought in the United States since legal realism petered out a half century ago ${ }^{1}$.

O Brasil vive atualmente uma crise fiscal, desemprego alto, endividamento de famílias e empresas e os juros altos retardam o fim da

\footnotetext{
${ }^{1}$ A análise econômica da lei, que atualmente existe não apenas nos Estados Unidos, mas também na Europa, esta que possui a sua própria próspera associação de direito e economia, possui tanto o aspecto positivo (isto é, descritivo), quanto normativo. Ela busca explicar e prever o comportamento de participantes e pessoas reguladas pela lei. Também busca melhorar as leis ao evidenciar consequências não intencionais ou indesejadas de leis existentes ou leis propostas, seja em termos de eficiência econômica, ou de distribuição de proventos e riquezas, ou outros valores. A empresa não é meramente uma torre de marfim, pelo menos não nos Estados Unidos, onde o movimento de direito e economia é conhecido por ter influenciado a reforma legal em diversas áreas relevantes. Essas áreas incluem antitruste, a regulação de serviços de utilidade pública e transportadoras públicas, regulação ambiental, o cômputo de danos em ações de danos pessoais, a regulação dos mercados de valores mobiliários, a diretrizes do sentenciamento federal, a divisão da propriedade e o cálculo da pensão alimentícia em casos de divórcio, e a lei que rege os investimentos por fundos de pensão e outros fideicomissários, e por ter sido um fator significativo no movimento de desregulação e na ideologia do livre mercado em geral. A maioria das grandes escolas de direito e muitas das menores tem um ou dois economistas por tempo integral dentre seu corpo docente; certo número de professores de direito tem PHDs em economia; existem seis jornais acadêmicos devotados à análise econômica do direito, com um sétimo a caminho; o uso de economistas como testemunhas-especialistas tem se tornado convencional no âmbito de importantes campos; opiniões judiciais se referem a conceitos econômicos e citam livros e artigos econômicos; e um certo número de juízes federais, incluindo um dos Ministros da Suprema Corte (Stephen Breyer), são ex-alunos do movimento de direito e economia. A análise econômica do direito é geralmente considerada o mais significativo desenvolvimento do pensamento jurídico nos Estados Unidos desde que o realismo legal desapareceu há meio século atrás.* (Tradução livre). Disponível em: <p.3 de http://m.law.uchicago.edu/files/files/53.Posner.Values_0.pdf >. Acesso em: 24 mai. 2017.
} 
recessão ${ }^{2}$, em parte ainda herança de 2008. Foi recorde o número de empresas que pediu recuperação judicial em 2016: um aumento de 44,8\% ante 2015, sendo o maior resultado desde a entrada em vigor da Nova Lei de Falências, em junho de $2005^{3}$.

A recessão econômica prejudicou a geração de caixa das empresas, que também se depararam com o crédito caro e escasso, diz o birô de crédito.

As micro e pequenas empresas lideraram a lista de recuperacão judicial em $\underline{\text { 2016, }}$ com 1.134 pedidos, seguidas pelas médias (470) e pelas grandes empresas (259).

Quanto aos pedidos de falência, houve 1.852 solicitações em 2016, aumento de $3,9 \%$ em relação aos 1.783 feitos em 2015. É o maior número em quatro anos ${ }^{4}$.

O quadro abaixo evidencia que em 2016 o Estado de São Paulo, estado que lidera o ranking de constituições de empresas, teve 97.470 extinções frente a 164.900 constituições, ou seja, as extinções representaram 59\% das constituições. Já o estado de Minas Gerais, segundo no ranking de constituições, viu o número de extinções quase superar o de constituições, com uma diferença de apenas 3.352, o que corrobora com os dados gerais já apontados.

2 Disponível em: <http://especiais.g1.globo.com/economia/2016/quando-o-brasil-vai-sair-darecessao/>. Acesso em: 19 mai. 2017.

3 Disponível em: <http://www.valor.com.br/brasil/4824392/pedidos-de-recuperacao-judicialbatem-recorde-em-2016-nota-serasa>. Acesso em: 20 mai. 2017.

${ }^{4}$ Ibid., Acesso em: 20 mai. 2017. 
Figura 1: Ranking das Juntas Comerciais segundo Movimento de Constituição, Alteração e Extinção de Empresas

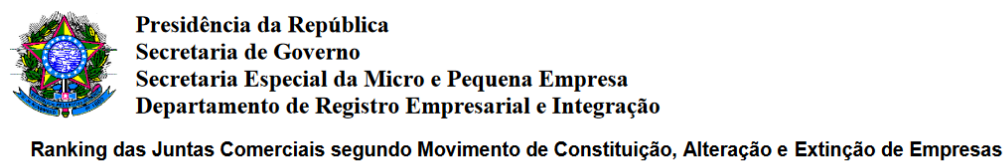

\begin{tabular}{|c|c|c|c|c|c|c|c|c|c|c|c|c|}
\hline \multirow{3}{*}{ Ordem } & \multirow{2}{*}{\multicolumn{3}{|c|}{ Constituição }} & \multirow{2}{*}{\multicolumn{3}{|c|}{ Alteração }} & & & & \multicolumn{3}{|c|}{ Período: Janeiro a Dezembro de 2016} \\
\hline & & & & & & & \multicolumn{3}{|c|}{ Extinção } & Movim & into Total & \\
\hline & Junta Comercial & Quantidade & $\%$ & Junta Comercial & Quantidade & $\%$ & Junta Comercial & Quantidade & $\%$ & Junta Comercial & Quantidade & $\%$ \\
\hline 1 & São Paulo & 164.900 & $38,42 \%$ & São Paulo & 817.035 & $46,72 \%$ & São Paulo & 97.470 & $26,47 \%$ & São Paulo & 1.079.405 & $42,39 \%$ \\
\hline 2 & Minas Gerais & 39.987 & $9,32 \%$ & Minas Gerais & 189.355 & $10,83 \%$ & Rio Grande do Sul & 42.396 & $11,51 \%$ & Minas Gerais & 265.977 & $10,45 \%$ \\
\hline 3 & Rio de Janeiro & 31.984 & $7,45 \%$ & Rio Grande do Sul & 92.864 & $5,31 \%$ & Minas Gerais & 36.635 & $9,95 \%$ & Rio Grande do Sul & 164.844 & $6,47 \%$ \\
\hline 4 & Rio Grande do Sul & 29.584 & $6,89 \%$ & Rio de Janeiro & 78.485 & $4,49 \%$ & Distrito Federal & 17.260 & $4,69 \%$ & Rio de Janeiro & 125.551 & $4,93 \%$ \\
\hline 5 & Bahia & 21.160 & $4,93 \%$ & Santa Catarina & 62.428 & $3,57 \%$ & Santa Catarina & 15.463 & $4,20 \%$ & Santa Catarina & 97.572 & $3,83 \%$ \\
\hline 6 & Santa Catarina & 19.681 & $4,58 \%$ & Bahia & 51.068 & $2,92 \%$ & Bahia & 15.280 & $4,15 \%$ & Bahia & 87.508 & $3,44 \%$ \\
\hline 7 & Goiás & 17.847 & $4,16 \%$ & Paraná & 46.023 & $2,63 \%$ & Rio de Janeiro & 15.082 & $4,10 \%$ & Distrito Federal & 74.288 & $2,92 \%$ \\
\hline 8 & Distrito Federal & 11.416 & $2,66 \%$ & Distrito Federal & 45.612 & $2,61 \%$ & Pernambuco (1) & 14.485 & $3,93 \%$ & Goiás & 67.615 & $2,66 \%$ \\
\hline 9 & Ceará & 10.971 & $2,56 \%$ & Goiás & 38.758 & $2,22 \%$ & Pará & 13.626 & $3,70 \%$ & Pará & 60.088 & $2,36 \%$ \\
\hline 10 & Pará & 9.139 & $2,13 \%$ & Pará & 37.323 & $2,13 \%$ & Paraná & 13.258 & $3,60 \%$ & Paraná & 59.795 & $2,35 \%$ \\
\hline 11 & Maranhão & 8.956 & $2,09 \%$ & Mato Grosso & 36.818 & $2,11 \%$ & Mato Grosso & 12.487 & $3,39 \%$ & Mato Grosso & 57.976 & $2,28 \%$ \\
\hline 12 & Pernambuco (1) & 8.866 & $2,07 \%$ & Pernambuco (1) & 33.717 & $1,93 \%$ & Goiás & 11.010 & $2,99 \%$ & Pernambuco (1) & 57.068 & $2,24 \%$ \\
\hline 13 & Mato Grosso & 8.671 & $2,02 \%$ & Rio Grande do Norte & 27.552 & $1,58 \%$ & Maranhão & 10.079 & $2,74 \%$ & Ceará & 46.267 & $1,82 \%$ \\
\hline 14 & Espírito Santo & 7.711 & $1,80 \%$ & Ceará & 26.144 & $1,49 \%$ & Ceará & 9.152 & $2,49 \%$ & Maranhão & 42.906 & $1,68 \%$ \\
\hline 15 & Mato Grosso do Sul & 5.750 & $1,34 \%$ & Mato Grosso do Sul & 25.505 & $1,46 \%$ & Paraíba & 7.252 & $1,97 \%$ & Rio Grande do Norte & 36.279 & $1,42 \%$ \\
\hline 16 & Rio Grande do Norte & 5.544 & $1,29 \%$ & Maranhão & 23.871 & $1,36 \%$ & Alagoas & 7.166 & $1,95 \%$ & Mato Grosso do Sul & 33.925 & $1,33 \%$ \\
\hline 17 & Amazonas & 4.696 & $1,09 \%$ & Paraiba & 20.936 & $1,20 \%$ & Espirito Santo & 6.086 & $1,65 \%$ & Paraíba & 32.783 & $1,29 \%$ \\
\hline 18 & Paraiba & 4.595 & $1,07 \%$ & Amazonas & 19.659 & $1,12 \%$ & Amazonas & 6.022 & $1,64 \%$ & Amazonas & 30.377 & $1,19 \%$ \\
\hline 19 & Alagoas & 4.246 & $0,99 \%$ & Alagoas & 16.823 & $0,96 \%$ & Sergipe & 4.664 & $1,27 \%$ & Alagoas & 28.235 & $1,11 \%$ \\
\hline 20 & Piauí & 3.513 & $0,82 \%$ & Espírito Santo & 14.312 & $0,82 \%$ & Rio Grande do Norte & 3.183 & $0,86 \%$ & Espírito Santo & 28.109 & $1,10 \%$ \\
\hline 21 & Sergipe & 3.178 & $0,74 \%$ & Sergipe & 13.200 & $0,75 \%$ & Mato Grosso do Sul & 2.670 & $0,73 \%$ & Sergipe & 21.042 & $0,83 \%$ \\
\hline 22 & Tocantins & 3.175 & $0,74 \%$ & \begin{tabular}{|l|l} 
Piaú \\
\end{tabular} & 8.122 & $0,46 \%$ & Amapá & 2.311 & $0,63 \%$ & Piauí & 12.699 & $0,50 \%$ \\
\hline 23 & Amapá & 961 & $0,22 \%$ & Tocantins & 7.661 & $0,44 \%$ & Acre & 1.536 & $0,42 \%$ & Tocantins & 12.189 & $0,48 \%$ \\
\hline 24 & Rondônia & 816 & $0,19 \%$ & Rondônia & 5.065 & $0,29 \%$ & Tocantins & 1.353 & $0,37 \%$ & Amapá & 7.507 & $0,29 \%$ \\
\hline 25 & Acre & 752 & $0,18 \%$ & Acre & 4.274 & $0,24 \%$ & Piaú & 1.064 & $0,29 \%$ & Rondônia & 6.785 & $0,27 \%$ \\
\hline 26 & Roraima & 645 & $0,15 \%$ & Amapá & 4.235 & $0,24 \%$ & Rondônia & 904 & $0,25 \%$ & Acre & 6.562 & $0,26 \%$ \\
\hline 27 & Paraná & 514 & $0,12 \%$ & Roraima & 2.077 & $0,12 \%$ & Roraima & 371 & $0,10 \%$ & Roraima & 3.093 & $0,12 \%$ \\
\hline & Total: & 429.258 & & Total: & 1.748 .922 & & Total: & 368.265 & & Total Geral: & 2.546 .445 & \\
\hline
\end{tabular}

(1) Aguardando atualização dos dados referentes ao periodo entre Agosto e Dezembro da Junta Comercial de Pernambuco - JUCEPE.

Fonte: Disponível em: <http://drei.smpe.gov.br/documentos/00-ranking-janeiro-adezembro2016.pdf $>^{5}$.

A verdade é que o cenário econômico atual é desfavorável às empresas em muitos aspectos, o que é piorado pelo Custo Brasil, que consiste no conjunto de dificuldades que encarecem os negócios no país, como fatores tributários, burocráticos e operacionais, conforme definição abaixo que consta do Guia de Economia do Senado Federal:

Custo Brasil - Denominação genérica dada a uma série de custos de produção, ou despesas incidentes sobre a produção, que tornam difícil ou desvantajoso para o exportador brasileiro colocar seus produtos no mercado internacional, ou então tornam inviável ao produtor nacional competir com os produtos importados. Tais custos estariam relacionados com aspectos legais de toda sorte como os da legislação trabalhista (que gera pesados encargos sociais); institucionais (excesso de burocracia para a instalacãa de empresas ou para a exportação de produtos); tributários (excesso de impostos, contribuicões e taxas) sobre produtos que direta ou indiretamente participam das exportações ou sofrem concorrência de produtos estrangeiros; de infraestrutura (falta de estradas de rodagem bem conservadas, deficiência de estradas de ferro e de hidrovias, comunicações deficientes e caras, além de portos e aeroportos

\footnotetext{
${ }^{5}$ Acesso em: 19 mai. 2017.
} 
ineficientes e de alto custo operacional); corporativas (domínio de sindicatos de trabalhadores sobre certos tipos de atividade, dificultando a incorporação do progresso técnico e o aumento da produtividade), entre outros ${ }^{6}$.

O infográfico abaixo busca ilustrar, muito resumidamente, a realidade do Custo Brasil.

Figura 2: Custo Brasil Ilustrado

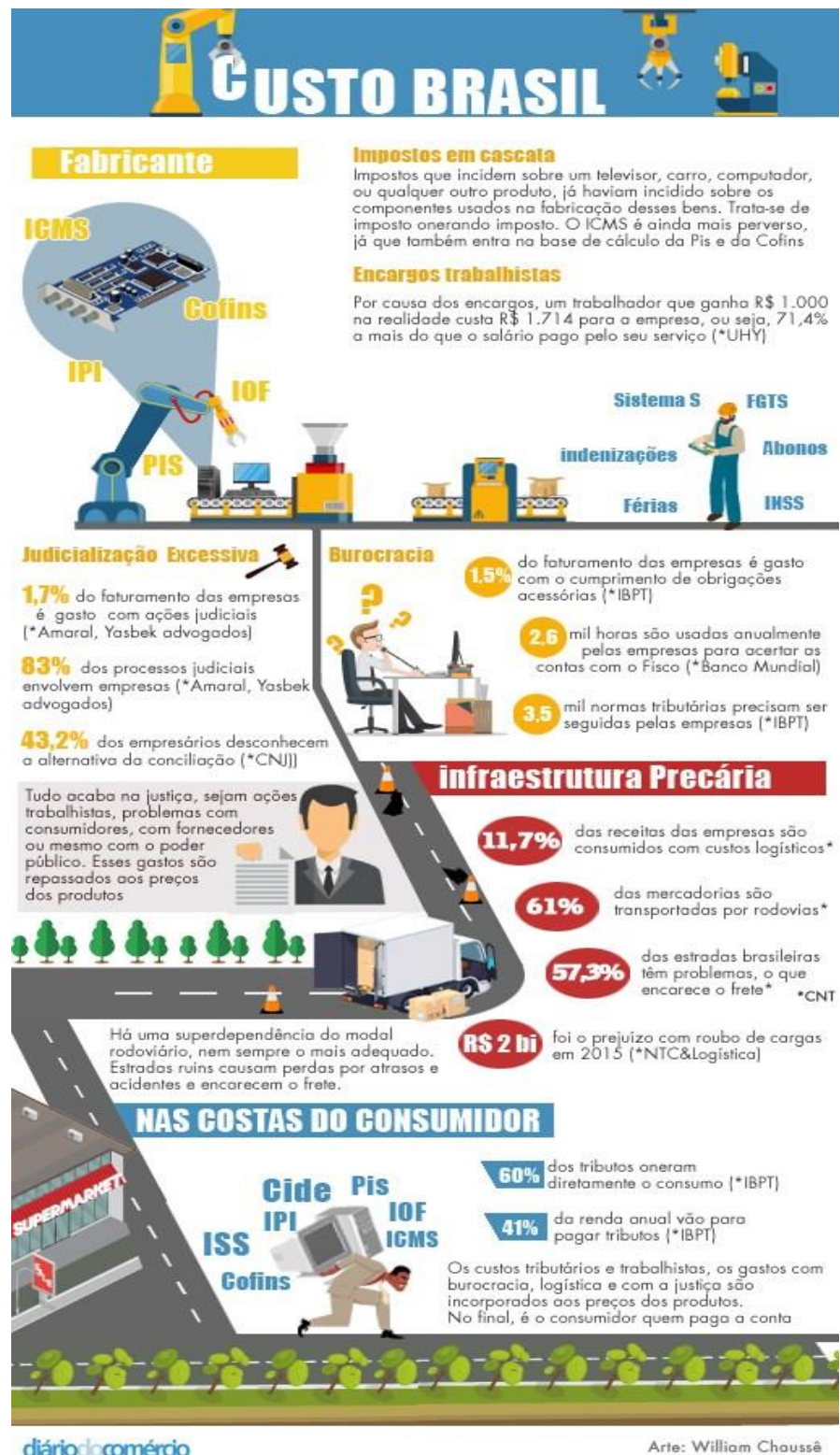

Fonte: Disponível em:

$<$ https://www.superempreendedores.com/web/infograficos/custo-brasil-aincrivel-carga-tributaria-brasileira/ $>7$.

\footnotetext{
${ }^{6}$ Disponível em: 〈https://www12.senado.leg.br/manualdecomunicacao/guia-de-economia〉. Acesso em: 23 mai. 2017.

${ }^{7}$ Acesso em: 19 mai. 2017.
} 
Aos custos supramencionados, vale adicionar a instabilidade política que tem assolado o país. Escândalos de corrupção, por exemplo, impactam a economia em larga escala, aumentando a recessão. A consultoria Tendencias apontou em 2016 que a operação Lava Jato teria um impacto negativo de $2,5 \%$ do Produto Interno Bruto (PIB) e a consultoria GO Associados afirmou que os impactos diretos ou indiretos giram em torno de $\mathrm{R}$ \$ 142,6 bilhões, o que tem como consequência demissões em massa e, por conseguinte, contração da renda (queda de 0,5\% em 2016), algo que não acontecia desde $2003^{8}$. Pesquisa da Federação de Indústrias do Estado da São Paulo (FIESP) aponta ainda em estudo que "o custo médio da burocracia no Brasil é estimado entre $1,47 \%$ a $2,76 \%$ do PIB, isto é, de R\$ 46,3 bilhões a R\$ 86,7 bilhões (em reais de 2009)"'9.

Em 2016, objetivando abrir meu próprio negócio, uma plataforma online denominada "Negócios\&Etc." - que conectaria consultorias de pequeno porte com micro e pequenas empresas - realizei uma pesquisa de mercado, online, veiculada através da rede social Facebook, com a participação de 83 brasileiros, entre empreendedores e aqueles que desejavam no futuro ter seu negócio. Os participantes deveriam preencher um formulário, criado por mim no website Qualtrics ${ }^{10}$, com perguntas de multiplaescolha predeterminadas, facultando ainda a opção pela resposta "Outros", que seria dissertativa. A pesquisa não requeria resposta obrigatória de questão alguma, mas mais de $90 \%$ dos que responderam a questão "Você considera ter um negócio no Brasil difícil?" reagiram afirmativamente, em outra questão que indagava o motivo, $90 \%$ culpou os altos impostos e $80 \%$ a burocracia pela dificuldade encontrada (vide abaixo).

\footnotetext{
${ }^{8}$ Disponível em: <http://dinheirama.com/blog/2016/01/20/impactos-operacao-lava-jato-economiabrasileira/>. Acesso em: 20 mai. 2017.

${ }^{9}$ FIESP. Relatório Burocracia: custos econômicos e propostas de combate. Equipe Técnica. Junho de 2010. Disponível em: <http://www.fiesp.com.br/indices-pesquisas-e-publicacoes/relatorioburocracia-custos-economicos-e-propostas-de-combate/>. Acesso em: 24 mai. 2017.

${ }^{10}$ Disponível em: <https://www.qualtrics.com/>. Acesso em: 25 mai. 2017.
} 
Figura 3: Questão 4 da Pesquisa de Mercado 'Negócios\&Etc' Q4 - Você considera ter um negócio no Brasil difícil?

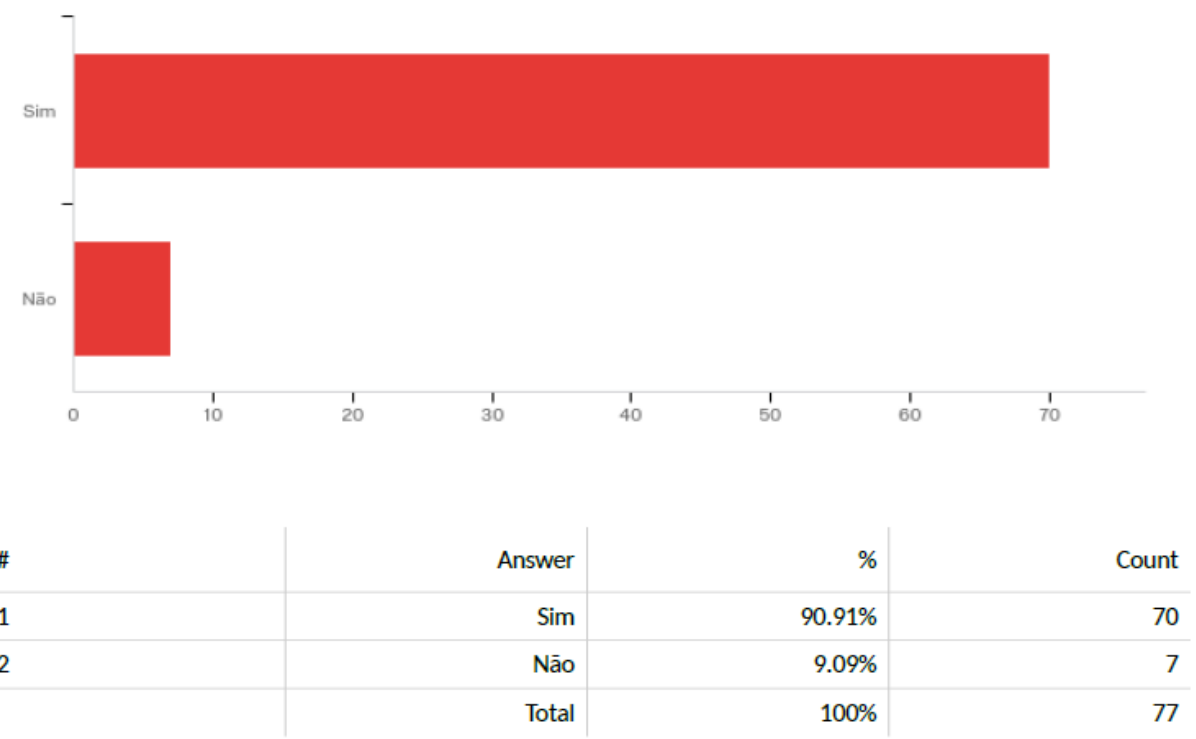

Fonte: Autoria própria.

Figura 4: Questão 5 da Pesquisa de Mercado 'Negócios\&Etc' Q5 - Por que você considera ter um negócio no Brasil difícil?

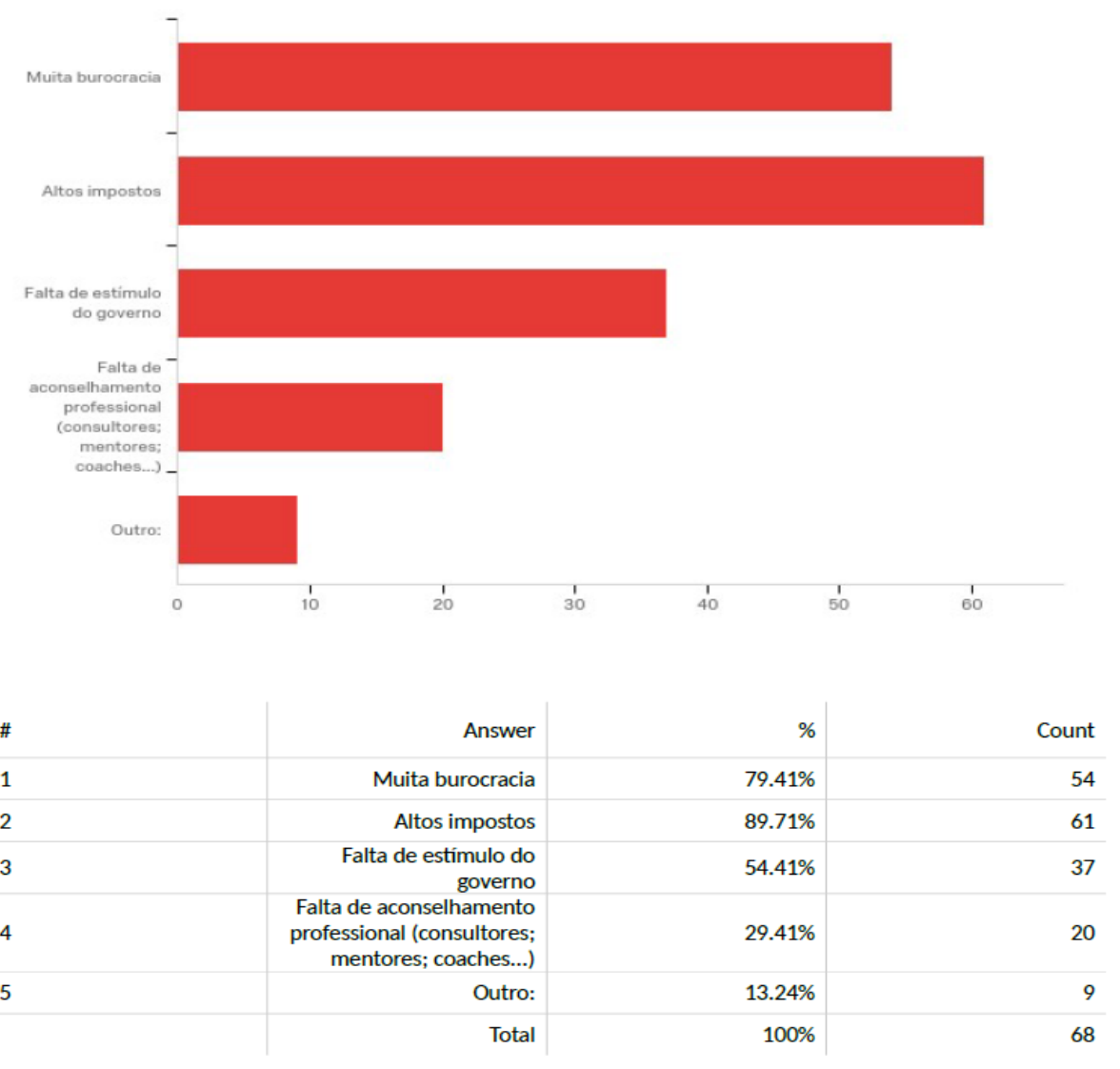

Fonte: Autoria própria. 
A realidade é que os pequenos negócios são os grandes prejudicados nessa realidade hostil, como evidenciado neste capítulo com o indicador de que em 2016 as micro e pequenas empresas lideraram os pedidos de recuperação judicial. A chave para o crescimento econômico e social do país, uma vez que empresas geram empregos e realizam inúmeros investimentos em áreas diversas, está no amadurecimento dos pequenos negócios para que um dia se tornem grandes, em um ambiente favorável ao crescimento, criando um ecossistema de vasta concorrência e, por conseguinte, invariavelmente melhorando a qualidade dos serviços. E se isso já não bastasse para refletir a importância de qualquer empresa no desempenho de sua função social, os números comprovam a relevância econômica das micro e pequenas empresas que em 2011 somavam 27\% do PIB. Portanto, para o surgimento de um ambiente favorável, não trato aqui sequer de incentivo do governo, mas simplesmente de impedir que se criem entraves desnecessários e para isso se faz essencial discutir as leis vigentes.

Figura 5: Valor adicionado das Micro e Pequenas Empresas na Economia Nacional 2009 a 2011.

\begin{tabular}{|l|c|c|c|}
\hline \multirow{2}{*}{$\begin{array}{l}\text { \% DO VALOR ADICIONADO DAS MICRO } \\
\text { E PEQUENAS EMPRESAS }\end{array}$} & 2009 & 2010 & 2011 \\
\hline SERVIÇOS & $9,0 \%$ & $9,3 \%$ & $10,0 \%$ \\
\hline COMÉRCIO & $9,5 \%$ & $9,2 \%$ & $9,1 \%$ \\
\hline INDÚSTRIA & $8,6 \%$ & $8,3 \%$ & $7,8 \%$ \\
\hline MICRO E PEQUENAS EMPRESAS & $27,1 \%$ & $26,7 \%$ & $27,0 \%$ \\
\hline
\end{tabular}

Fonte: Sebrae e FGV, a partir de dados do $\mathrm{IBGE}^{11}$.

Dito isto, concluo este capítulo afirmando que esse trabalho terá uma abordagem genuinamente prática e tratará dos pequenos negócios, se restringindo aos unipessoais, sugerindo a derrubada de algumas barreiras em críticas aos institutos do Empresário Individual, MEI, EIRELI, Microempresa e Empresa de Pequeno Porte, como será explicado mais

\footnotetext{
${ }^{11}$ SEBRAE. Valor adicionado das Micro e Pequenas Empresas na Economia Nacional 2009 a 2011. Disponível em:

<https://www.sebrae.com.br/Sebrae/Portal\%20Sebrae/Estudos\%20e\%20Pesquisas/Participacao\%2 0das\%20micro\%20e\%20pequenas\%20empresas.pdf>. Acesso em: 16 mai. 2017.
} 
adiante. Apesar desses institutos terem naturezas jurídicas distintas em grande medida, estou tratando da práxis, do momento decisório do aspirante a empresário que quando se determina a desempenhar atividade econômica ele não se perguntará qual será a estrutura societária e em seguida qual o enquadramento tributário, ele se perguntará se deve constituir uma MEI ou uma EIRELI, tendo essa escolha diferentes e relevantes impactos em seu negócio. 


\section{CAPÍTULO 1 - DEFINIÇÃO DE AUTÔNOMO}

\subsection{Da Natureza Empresária}

Defino neste subcapítulo o escopo deste trabalho por delimitar o que considerei por "Autônomo" - tendo em vista que o termo por si só não é termo jurídico - afastando uma análise de viés trabalhista, uma vez que essa tese acadêmica se presta a analisar as estruturas jurídicas disponíveis no ordenamento brasileiro para possibilitar a circulação de bens e serviços pelo desempenho de atividade empresária individual - sócio único, não se excluindo, porém, colaboradores. Não trato aqui, de modo algum, de subterfúgio jurídico, de termo vulgar "pejotização", para driblar a legislação trabalhista, pelo contrário, trato do animus legítimo e verdadeiro de empreender, trato, portanto, do desempenho de atividade empresária sem pluralidade de sócios. Isto posto, não adentrarei nos meandros dos profissionais liberais, em razão da exclusão legal daquele que exerce profissão de natureza intelectual, científica, literária ou artística da categoria de empresário. Tais profissionais possuem regramento específico, o que não integra o escopo deste trabalho. Dito isto, foco nas figuras do Empresário Individual (EI), Microempreendedor Individual (MEI) e Empresa Individual de Responsabilidade Limitada (EIRELI), de modo a fazer críticas pontuais a abordagens jurídicas e práticas no Brasil.

Para que fique claro que este trabalho se propõe a discutir a atividade empresária, se faz necessário definir diversos conceitos, a começar por quem pode ser considerado "empresário" para fins jurídicos, definição esta que se encontra no Art. 966 da Lei no. 10.406/2002, o Código Civil, conforme abaixo transcrito:

Art. 966. Considera-se empresário quem exerce profissionalmente atividade econômica organizada para a produção ou a circulação de bens ou de serviços. 
Parágrafo único. Não se considera empresário quem exerce profissão intelectual, de natureza científica, literária ou artística, ainda com o concurso de auxiliares ou colaboradores, salvo se o exercício da profissão constituir elemento de empresa.

Do conceito de "empresário" extraímos o de "empresa". O Doutor em Direito Empresarial pela PUC-SP, André Luiz Santa Cruz Ramos, destrincha, de modo objetivo, cada característica do caput do Art. 966, CC que define empresário. O referido autor ora se refere a empresário, e ora a empresa:

Da primeira expressão destacada, pode-se extrair o seguinte: só será empresário aquele que exercer determinada atividade econômica de forma profissional, ou seja, que fizer do exercício daquela atividade a sua profissão habitual.

Ao destacarmos a expressão atividade econômica, por sua vez, queremos enfatizar que empresa é uma atividade exercida com intuito lucrativo.

A terceira expressão destacada - organizada - significa, como bem assinala a doutrina, que empresário é aquele que articula os fatores de produção (capital, mão de obra, insumos e tecnologia). No mesmo sentido, diz-se que o exercício de empresa pressupõe, necessariamente, a organização de pessoas e meios para o alcance da finalidade almejada. Como dizia Asquini, o empresário é responsável pela "prestação de um trabalho autônomo de caráter organizador", e é isso, junto com a assunção dos riscos do empreendimento, que justifica a possibilidade de ele auferir lucro ${ }^{12}$.

A citação indireta ao doutrinador italiano Alberto Asquini se faz aqui providencial, uma vez que trata de forma expressa do empresário como aquele que presta trabalho autônomo, porém traz como elemento essencial a "organização", que de fato consta como requisito no Art. 966, CC, porém vale ressalvar que não deve hoje ser fator excludente à definição de empresário, de modo absoluto, considerando a realidade contemporânea que traz figuras dinâmicas como o microempresário, por exemplo. $\mathrm{O}$ próprio Doutor André Luiz Santa Cruz é claro quanto a isso:

\footnotetext{
${ }^{12}$ RAMOS, André Luiz Santa Cruz. Direito empresarial esquematizado. $6^{\mathrm{a}}$ ed. rev. atual. e ampl. Rio de Janeiro: Forense; São Paulo: MÉTODO, 2016. p. 75.
} 
Fábio Ulhôa Coelho, ao analisar o requisito da organização para a caracterização da empresa, chega a afirmar que não se deve considerar como empresário aquele que não organiza nenhum dos fatores de produção. Parece-nos que essa ideia fechada de que a organização dos fatores de produção é absolutamente imprescindível para a caracterização do empresário vem perdendo força no atual contexto da economia capitalista. Com efeito, basta citar o caso dos microempresários, os quais, não raro, exercem atividade empresarial única ou preponderantemente com trabalho próprio. Pode-se citar também o caso dos empresários virtuais, que muitas vezes atuam completamente sozinhos, resumindo-se sua atividade à intermediação de produtos ou serviços por meio da internet ${ }^{13}$.

Ainda a respeito dessa questão, vale dizer que o MEI, conforme esclarece o doutrinador Rubens Requião, é, em verdade, um enquadramento tributário do empresário no sistema de micro e pequenas empresas (vide abaixo). O MEI é um enquadramento tributário benéfico facultado aos empresários individuais que desempenham as atividades constantes do Anexo XIII da Resolução do Comitê Gestor do Simples Nacional - CGSN $\mathrm{n}^{\text {o }}$ 94, de 29 de novembro de 2011 e auferem renda bruta de até $\mathrm{R} \$$ 60.000,00 ao ano, conforme Art. 18-A, $\$ 1^{\circ}$ da Lei Complementar 123/2006 (alteração para $\mathrm{R} \$ 81.000,00$ em vacatio legis até $1^{\circ}$ de janeiro de 2018), em uma tentativa de formalização dessas categorias e consequente arrecadação de tributos:

O empresário pode exercitar a atividade empresarial individualmente: será então um empresário individual.

À firma individual (hoje denominada firma mercantil individual pela Lei no. 8.934, de 18-11-1994, art. 32, II, a), do empresário individual, registrada no Registro do Comércio, atualmente Registro Público de Empresas Mercantis, chama-se também de empresa individual e empresário, pelo Código Civil. ${ }^{1} \mathrm{O}$ Tribunal de Justiça de Santa Catarina explicou muito bem que o comerciante singular, vale dizer, o empresário individual, é a própria pessoa física ou natural, respondendo os seus bens pelas obrigações que assumiu, quer sejam civis, quer comerciais. A transformação de firma individual em pessoa jurídica é uma ficção do direito tributário, somente para o efeito do imposto de renda (Ap. Cív. No. 8.447 - Lajes, in Bol. Jur. ADCOAS, no. 18.878/73). $\underline{\text { A }}$ Lei Complementar no. 123/2006, alterada pela Lei Complementar no. 128/2008, introduziu, para fins tributários e de enquadramento no sistema de benefícios dedicados à micro e pequena empresa, o conceito de microempreendedor individual - MEI -, como se vê no art. 18-A, já

\footnotetext{
${ }^{13}$ RAMOS, 2016, p. 75.
} 
examinando nos itens 36-C e seguintes, que nada mais é que o empresário do Código Civil ${ }^{14}$.

Ressalte-se, porém, que o intuito do legislador ao criar o MEI foi primordialmente de formalização e estímulo à atividade empresária, uma vez que a contribuição por cada MEI é muito reduzida, fazendo com que, em muitos casos, uma análise custo-benéfica favoreça à remissão de tributos por entes subnacionais de modo a ser menos custoso à administração pública do que a cobrança dos débitos por meio judicial ou administrativo. Nas palavras do tributarista Ricardo Alexandre:

Levando em consideração os diminutos valores recolhidos pelo MEI a título de ICMS e ISS, é bastante possível que, no caso de inadimplemento, o custo de cobrança administrativa e judicial supere em muito os valores a serem recebidos. Considerando tal possibilidade, a Lei Complementar 147/2014 incluiu no art. 18-A da LC 123/2006 o $§ 15-A$, autorizando os entes subnacionais a conceder remissão dos citados débitos inadimplidos isolada ou simultaneamente ${ }^{15}$.

Vale lembrar que o MEI é registrado na Junta Comercial, mas o registro é automático e integrado, conforme consta do Art. $3^{\circ}$, III da Resolução No. 16/2009 do CGSIM:

Art. $3^{\circ} \mathrm{O}$ processo de registro, alteração, baixa e legalização do MEI observará as disposições da Lei $n^{\circ} 11.598$, de 3 de dezembro de 2007, da Lei Complementar $n^{\circ}$ 123, de 14 de dezembro de 2006, alterada pela Lei Complementar $\mathrm{n}^{\circ} 128$, de 19 de dezembro de 2008, da Lei n. 12. 470, de 01 de setembro de 2011, da Lei Complementar n. 139, de 11 de novembro de 2011, assim como as seguintes diretrizes específicas: (Redação dada pela Resolução CGSIM n 26, de 8 de dezembro de 2011).

\section{$[\ldots]$}

III - integrar, de imediato, ao Portal do Empreendedor, processos, procedimentos e instrumentos referentes à inscrição do Microempreendedor Individual na Secretaria da Receita Federal do Brasil RFB e nas Juntas Comerciais;

\footnotetext{
${ }^{14}$ REQUIÃO, Rubens Edmundo. Curso de Direito Comercial. $31^{\text {a }}$. ed. rev. E atual. $1^{\circ}$ v. São Paulo: Saraiva, 2012. p. 112-113.

15 ALEXANDRE, Ricardo. Direito tributário esquematizado. $10^{\mathrm{a}} \mathrm{ed}$. rev., atual. e ampl. Rio de Janeiro: Forense; São Paulo: MÉTODO, 2016. p. 659.
} 
Tal esclarecimento também consta das Perguntas Frequentes do "Portal do Empreendedor":

3.5 - Preciso levar algum documento para a Junta Comercial? Quais? A Junta Comercial precisa aprovar meu pedido de formalização como MEI?

Não é necessário encaminhar nenhum documento à Junta Comercial. Após o cadastramento, o CNPJ, a inscrição na Junta Comercial, no INSS e o Alvará Provisório de Funcionamento são obtidos imediatamente, gerando um documento único, que é o Certificado da Condição de Microempreendedor Individual $\mathrm{CCMEI}^{16}$.

Logo, uma vez que resta claro que MEI é um enquadramento tributário do empresário, passamos a uma análise complementar das já citadas características constantes do Art. 966, CC. Rememoro aqui o requisito da "atividade econômica", esta que, em verdade, indica que o empresário, ao optar por tornar-se empresário e, portanto, desempenhar atividade econômica, tomou para si o direito do lucro advindo desta atividade, mas, ao mesmo tempo, assumiu os possíveis riscos do negócio. Nas palavras do Doutor André Luiz Santa Cruz Ramos:

[...] Mas não é só à ideia de lucro que a expressão atividade econômica remete. Ela indica também que o empresário, sobretudo em função do intuito lucrativo de sua atividade, é aquele que assume os riscos técnicos e econômicos dela ${ }^{17}$.

No que tange o vocábulo "profissionalmente" que consta também do Art. 966, CC, o Doutor André Luiz Santa Cruz Ramos enfatiza que a atividade econômica deve ser desenvolvida voltada para um mercado:

E mais. Além de denotar a abrangência da teoria da empresa, a expressão em análise também nos permite concluir que só restará caracterizada a empresa quando a produção ou circulação de bens ou serviços destinar-se ao mercado, e não ao consumo próprio ${ }^{18}$.

E Rubens Requião nos propõe um conceito de empresário:

\footnotetext{
${ }^{16}$ Disponível em: <http://www.portaldoempreendedor.gov.br/perguntas-frequentes/duvidasrelacionadas-ao-microempreendedor-individual-1/3-formalizacao-como-mei>. Acesso em: 16 mai. 2017.

${ }^{17}$ RAMOS, 2016, p. 75.

${ }^{18}$ Ibid., p. 76.
} 
O empresário é o sujeito que exercita a atividade empresarial. É ainda, como observa Ferri ${ }^{19}$, no todo ou em parte, o capitalista; desenvolve ele uma atividade organizada e técnica. É um servidor da organização de categoria mais elevada, à qual imprime o selo de sua liderança, assegurando a eficiência e o sucesso do funcionamento dos fatores organizados.

Dois elementos fundamentais - destacam geralmente os autores - servem para caracterizar a figura do empresário: a iniciativa e o risco. O poder de iniciativa pertence-lhe exclusivamente: cabe-lhe, com efeito, determinar o destino da empresa e o ritmo de sua atividade. Já se acentua em alguns países, como na França e na Alemanha, a redução desse poder de iniciativa do empresário, impondo-se-lhe, através da lei, a divisão desse poder de iniciativa, concedendo-se participação na direção da empresa a representantes dos empregados. Contudo, isso é verdade para determinadas empresas.

O empresário pode valer-se, e normalmente se vale, da atuação e colaboração de outrem, mas a ele cabe a decisão, a ele compete, no caso de diversidade de perspectiva, escolher o caminho que lhe pareça mais conveniente. Compensando o poder de iniciativa, os riscos são todos do empresário: goza $\underline{\text { ele das vantagens do êxito e amarga as desventuras do insucesso e da ruína }}^{20}$.

Como já dito anteriormente, do conceito de "empresário" decorre então o de "empresa" e o doutrinador José Edwaldo Tavares Borba, de abordagem conservadora no que tange ao requisito "organização" conforme já discutido acima - define empresa e empresário do seguinte modo:

A empresa era desse modo então definida como a estrutura fundada na organização dos fatores da produção (natureza, capital e trabalho) para o desenvolvimento de uma atividade econômica.

O empresário organiza e dirige a empresa, reunindo e coordenando os fatores para produção ${ }^{21}$.

Requião, por sua vez, também citado por Tavares Borba, entende não ser possível uma definição legal adequada, acreditando ser a econômica a melhor definição de empresa. Descreve então a evolução do conceito econômico:

\footnotetext{
${ }^{19}$ Giuseppe Ferri, italiano, doutrinador de direito comercial e professor da Universidade de Florença. Citado por Requião, Tavares Borba e outros doutrinadores brasileiros.

${ }^{20}$ REQUIÃO, 2012, p. 110-111.

${ }^{21}$ BORBA, José Edwaldo Tavares. Direito societário. $13^{\mathrm{a}}$ ed. ver. e atual. Rio de Janeiro: Renovar, 2012. p. 14.
} 
O Prof. Giuseppe Ferri observa que a produção de bens e serviços para o mercado não é consequência de atividade acidental ou improvisada, mas sim de atividade especializada e profissional, que se explica através de organismos econômicos permanentes nela predispostos. Esses organismos econômicos, que se concretizam na organização dos fatores de produção e se propõem a satisfação das necessidades alheias, e, mais precisamente, das exigências do mercado geral, tomam na terminologia econômica o nome da empresa.

Os economistas clássicos, no século XIX, haviam observado as organizações econômicas destinadas à produção, tendo J. B. Say exaltado a figura do empresário, mostrando que é ele 'o eixo a um tempo da produção e da repartição, aquele que adapta os recursos sociais às necessidades sociais e que remunera os colaboradores da obra cujo chefe é'. Na reação socialista dos reformadores, SaintSimon colocou no centro da sociedade a figura dos grandes empresários. Desde então, a Economia Política passou a considerar, com a relevância devida, o papel da empresa, como organização dos fatores de produção.

Assim - acentua Ferri - a empresa é um organismo econômico, isto é, assenta-se sobre uma organização fundada em princípios técnicos e leis econômicas. Objetivamente considerada, apresenta-se como uma combinação de elementos pessoais e reais, colocados em funcão de um resultado econômico, e realizada em vista de um intento especulativo de uma pessoa, que se chama empresário. Como criacão de atividade organizativa do empresário e como fruto de sua ideia, a empresa é necessariamente aferrada à sua pessoa, dele recebendo os impulsos para seu eficiente funcionamento.

\section{$[\ldots]$}

O conceito jurídico de empresa se assenta nesse conceito econômico. Em vão os juristas têm procurado construir um conceito jurídico próprio para tal organização. Sente-se em suas lições certo constrangimento, uma verdadeira frustração por não lhes haver sido possível compor uma síntese jurídica para empresa, tendo o comercialista de se valer da ideia formulada pelos economistas. Por isso, persistem os juristas no afã de edificar em vão uma original noção jurídica de empresa, como se fosse desdouro para a ciência jurídica transpor para o campo jurídico uma bem elaborada formulacão econômica ${ }^{22}$.

Aqui vale uma breve digressão diante do fato de que a passagem supracitada da obra de Rubens Requião reafirma o proposto na introdução deste trabalho, de modo a demonstrar que a economia e o direito não são ciências completamente desconexas entre si, independentes, opostas. São ciências complementares que precisam caminhar juntas, pois a organização social é sistêmica. Ou seja, não existe economia sem direito e direito sem economia ou melhor, existe, mas certamente prejudicadas em sua eficiência e efetividade.

${ }^{22}$ REQUIÃO, 2012, p. 75-76. 
Retornemos agora ao ponto principal deste capítulo, a partir do exposto, conclui-se que o empresário individual é aquele que exerce atividade empresária, conforme o Art. 966, CC, sem sócios e acrescenta-se ainda que respondendo com a totalidade de seu patrimônio. E o MEI, por sua vez, é um mero enquadramento tributário. Ora, mas é possível que reste dúvida acerca da natureza jurídica da EIRELI, uma vez que recebe a designação de "empresa" e não "empresário", e pelo fato de que expliquei até este ponto quem seria o empresário individual e o MEI, porém não a EIRELI. A natureza jurídica da EIRELI, contudo, ainda é um tanto quanto controvertida na doutrina. O Art. 44, VI, CC prevê a EIRELI como um novo tipo societário e o Art. 980-A, CC define as características da EIRELI em título próprio, o que nos leva a crer, inicialmente, que se trata de uma pessoa jurídica nova. Todavia, devido a uma certa imprecisão técnica do legislador, a discussão a respeito da natureza jurídica da EIRELI é grande. Define, portanto, Marcela Maffei Quadra Travassos, em sua obra "Empresa Individual de Responsabilidade Limitada (EIRELI) - Análise constitucional do instituto, unipessoalidade e mecanismos de controle de abusos e fraudes", a EIRELI como sendo sociedade unipessoal, sociedade unipessoal de tipo próprio para ser mais específica, apesar de muitos autores considerarem a EIRELI sociedade limitada unipessoal. Vide abaixo definição de Marcela Travassos:

Diz-se que a EIRELI é sociedade unipessoal de tipo próprio na medida em que possui características e elementos próprios, distintos das demais espécies de sociedades previstas no Código Civil e na Lei das Sociedades por Ações, tais como a unipessoalidade permanente e a exigência de capital mínimo integralizado no ato da constituição.

Tais características distinguem-na, inclusive, das sociedades limitadas, não se entendendo correto afirmar que a aplicação das regras de sociedades limitadas, no que for compatível, com a EIRELI ( $\$ 6^{\circ}$, do artigo 980-A) teria o condão de lhe atribuir a feição de sociedade limitada unipessoal. A aplicação das regras de sociedades limitadas faz-se em caráter subsidiário e somente no que não conflitar com a qualidade unipessoal permanente da EIRELI, devendo estar em consonância com suas características principais, como capital mínimo integralizado e demais regras inerentes ao tipo próprio que constitui. 
Dentre os autores que atribuem à EIRELI a natureza de sociedade unipessoal, há quem sustente tratar-se de típica sociedade limitada unipessoal, como se pode perceber das seguintes passagens abaixo transcritas a título exemplificativo ${ }^{23}$ :

Marcela Travassos cita então trecho da obra de Paulo César Aragão e

Gisela Sampaio da Cruz:

A sociedade limitada unipessoal, no direito brasileiro, foi designada de 'Empresa Individual de Responsabilidade Limitada', EIRELI (CC, art. 980-A). Ao examinar-se a classificação das sociedades segundo a quantidade de sócios, criticou-se a opção e demonstrou-se que a interpretação sistemática do direito positivo conduz à conclusão de que não se trata de nova espécie de pessoa jurídica, mas do nomen iuris dado à sociedade limitada unipessoal. É a EIRELI, a nosso sentir, uma modalidade de sociedade limitada, com o traço característico, que lhe imprime particularidade, de ser formada por um único sócio.

Trata-se, a bem da verdade, de uma autêntica sociedade unipessoal. E mais: a EIRELI nada mais é do que uma sociedade limitada unipessoal. Nesse sentido, é interessante notar que o art. 980-A, $\$ 3^{\circ}$, do Código Civil dispõe que a EIRELI poderá resultar da concentração das quotas de outra modalidade societária nas mãos de um único titular ${ }^{24}$.

Rubens Requião, por sua vez, sustenta que a EIRELI é uma personificação da empresa e esclarece então o motivo dessa escolha do legislador:

Cumpre lembrar que o empresário é definido pelo Código Civil (art. 966) como aquele que 'exerce profissionalmente atividade econômica organizada para a produção ou a circulação de bens ou de serviços'. Assim, aquele que agir nesse sentido poderá limitar sua responsabilidade, circunscrevendo-a ao capital ou patrimônio que especializar a tanto.

Não se trata, com o novo estatuto atribuído à pessoa natural que assume a condição acima referida, de um novo tipo societário, como foi o caso quando da criação das empresas públicas e da subsidiária integral, que romperam o requisito da multiplicidade de sócios para formar a entidade. Mas apenas se imputa à pessoa natural empresária um novo atributo, qualificado pela responsabilidade limitada ao capital que destacar para sua atividade, no que se distingue do empresário individual, que sofre responsabilidade ilimitada pelas suas obrigações. Esta última categoria, aliás, tenderá a desaparecer, como

23 TRAVASSOS, Marcela Maffei Quadra. Empresa individual de responsabilidade limitada (EIRELI): análise constitucional do instituto, unipessoalidade e mecanismos de controle de abusos e fraudes. Rio de Janeiro: Renovar, 2015. p. 163.

${ }^{24}$ Ibid., p. 164. 
ocorreu com as sociedades de responsabilidade ilimitada, superadas pelas sociedades de responsabilidade limitada e pelas sociedades por ações ${ }^{25}$.

Diante do dito até este ponto, considerando a denominação da EIRELI de "empresa" e a discussão acerca de sua natureza jurídica, é importante distinguir "empresa" de "sociedade" e deixar claro que um tipo não pressupõe o outro. Nas palavras de Requião:

A principal distinção, e mais didática, entre empresa e sociedade empresária é a que vê na sociedade o sujeito de direito, e na empresa, mesmo como exercício de atividade, o objeto do direito.

A sociedade empresária, desde que esteja constituída nos termos da lei, adquire categoria de pessoa jurídica. Torna-se capaz de direitos e obrigações. A sociedade, assim é empresária, jamais empresa. É a sociedade, como empresário, que irá exercitar a atividade produtiva.

A preocupação do jurista germânico Endemann, de considerar a empresa como personalidade jurídica, não vingou. Os juristas, em sua maioria, não admitem a empresa como sujeito de direito, como uma pessoa jurídica em si.

Outra distincão fácil é a de que empresa pode ser o exercício da atividade individual, de pessoa natural. É a empresa individual, contrapondo-se à empresa coletiva, que é a exercida pela sociedade empresária. A empresa não pressupõe, como se vê, necessariamente, uma sociedade empresária.

Além disso, pode haver sociedade empresária sem empresa. Duas pessoas, por exemplo, juntam seus cabedais, formam o contrato social, e o registram na Junta Comercial. Eis aí a sociedade, e, enquanto estiver inativa, a empresa não surge ${ }^{26}$.

A discussão acerca da natureza jurídica da EIRELI é relevantíssima na medida que traz consequências práticas já que considerar EIRELI novo tipo jurídico afasta a aplicação de normas que regem as sociedades:

Caso se chegue à conclusão de que é a sociedade unipessoal, o enquadramento da matéria será pela aplicação de institutos próprios das sociedades. Já no caso de se considerar a EIRELI pessoa jurídica distinta das sociedades, corre-se o risco de não se lhe ser possível aplicar a mesma disciplina já consolidada em relação a institutos como conflitos de interesses, desconsideração da personalidade jurídica e, principalmente, sujeição à Lei de Falência e Recuperação de Empresas (Lei no. 11.101/2005), que, como se sabe, tem como destinatário o empresário e as sociedades empresárias ${ }^{27}$.

\footnotetext{
${ }^{25}$ REQUIÃO, 2012, p. 113.

${ }^{26}$ Ibid., p. 86-87.

27 TRAVASSOS, 2015, p. 129.
} 
Digo ainda que esse trabalho abordará a categorização de Microempresas (ME) e Empresas de Pequeno Porte (EPP) porque tanto o empresário individual quanto a EIRELI podem ser enquadrados como tal.

Definida a natureza empresária da temática desta tese, se faz necessário excluir o não aplicável, conforme consta do subcapítulo a seguir.

\subsection{Do Não Empresário}

Uma vez definido quem é "empresário", se faz necessário definir quem não é, quem, portanto, não está incluso em minha conceituação de "Autônomo" e outras exceções legais que não serão enfocadas neste trabalho. O já referido Parágrafo Único do Art. 966, CC exclui as atividades intelectuais da natureza empresária, contudo, este artigo não se refere única e exclusivamente às atividades prestadas de forma individual, ou seja, não são também empresárias as sociedades formadas por profissionais intelectuais, chamadas sociedades uniprofissionais ou sociedades simples, e logo registradas no Registro Civil de Pessoas Jurídicas e não sociedades empresárias, registradas no Registro Público de Empresas Mercantis, conforme dispõem os Art. 967 e 1.150 do Código Civil de 2002:

Art. 967. É obrigatória a inscrição do empresário no Registro Público de Empresas Mercantis da respectiva sede, antes do início de sua atividade.

Art. 1.150. O empresário e a sociedade empresária vinculam-se ao Registro Público de Empresas Mercantis a cargo das Juntas Comerciais, e a sociedade simples ao Registro Civil das Pessoas Jurídicas, o qual deverá obedecer às normas fixadas para aquele registro, se a sociedade simples adotar um dos tipos de sociedade empresária.

Trecho da obra do Doutor André Luiz Santa Cruz Ramos também trata desta questão:

Tudo o que se disse no tópico antecedente parece se referir exclusivamente a profissionais intelectuais que exercem suas atividades individualmente, na qualidade de pessoas físicas. Mas essa ideia é equivocada. A regra do Art. 966, parágrafo único, do Código Civil vale também para as chamadas sociedades uniprofissionais, ou seja, sociedades constituídas por profissionais intelectuais cujo objeto social é justamente a exploração de suas profissões (por exemplo, 
uma sociedade formada por médicos para prestação de serviços médicos, uma sociedade formada por professores para prestação de serviços de ensino, uma sociedade formada por engenheiros para prestação de serviços de engenharia etc. $)^{28}$.

Vale excepcionar, porém, que sociedades cujo objeto social consistir em desempenho de atividades de caráter intelectual, mas constituir “elemento de empresa”, que consta do Parágrafo Único do Art. 966, CC, será considerada empresária. Por “elemento de empresa" leia-se a organização dos fatores de produção. Tavares Borba deixa claro a dificuldade, muitas das vezes, de aferição do "elemento de empresa":

Essa questão da organização, em determinadas situações, poderá dirigir-se para uma zona cinzenta, de difícil definição; nesses casos, os próprios organizadores, segundo a sua avaliação, indicarão o caminho, inscrevendo a sociedade no Registro Civil ou no Registro de Empresas. Nessas situações imprecisas, qualquer que seja o registro, a sociedade será regular, e desse registro resultará a sua condição de simples ou empresária.

O Código Civil, ao disciplinar a sociedade em comum, que seria a sociedade irregular, assim considera aquela que não se inscreveu (art. 986).

A irregularidade estaria na falta de inscrição, não na inscrição inadequada, tanto que a finalidade do registro, que é a publicidade e a fiscalização do cumprimento dos preceitos legais aplicáveis, estaria, de qualquer sorte, assegurada. A irregularidade (registro impróprio) ocorreria apenas quando a inadequação do registro fosse manifesta, ou quando houvesse evidente intuito de fraudar a lei. Nesses casos, o registro poderia ser desconstituído, ou ter os seus efeitos afastados, por decisão judicial ${ }^{29}$.

Tavares Borba ainda insere relevante nota de rodapé (nota 22) neste trecho, indicando que, na prática, muito mais vale para os órgãos de registro a declaração dos interessados definindo se a atividade possui natureza empresária ou não do que uma análise fática da organização dos fatores de produção:

Na prática, quando a situação é imprecisa, as Juntas Comerciais e os cartórios do Registro Civil, para efeito de concessão de registro, tem se baseado, de um modo geral, muito mais na declaração das partes do que em um exame rigoroso da

${ }^{28}$ RAMOS, 2016, p. 93.

${ }^{29}$ BORBA, 2012, p. 24-25. 
existência ou não de uma organização, até mesmo porque essa averiguação nem sempre seria factível ${ }^{30}$.

Apesar de não fazer parte do escopo deste trabalho, ainda na linha dos profissionais intelectuais, ressalvo que as sociedades de advogados são sociedades simples, mas segundo o Superior Tribunal de Justiça, para fins tributários, possuem 'índole empresarial'. Novamente nas palavras do Doutor André Luiz Santa Cruz Ramos:

O Código Civil não faz menção expressa nesse sentido, mas a Lei 8.906/1994 (Estatuto da Advocacia e da Ordem dos Advogados do Brasil) versa, em seus arts. 15 a 17, sobre a sociedades de advogados, dispondo que ela é uma 'sociedade civil de prestação de serviço de advocacia' submetida à regulação específica prevista na referida lei.

Diante disso, afirma-se que a sociedade de advogados é uma sociedade de natureza civil - simples, na dicção do novo Código Civil de 2002 - e organizada sob a forma de sociedade em nome coletivo, ou seja, respondem todos os sócios de maneira solidária e ilimitada pelas obrigações sociais.

Ora, se aplicarmos à risca a regra do Art. 966, parágrafo único, do Código Civil de 2002 às sociedades de advogados, forçoso seria reconhecer que os escritórios de advocacia com estrutura complexa - muito comuns hoje em dia, diga-se deixam de ser sociedades simples para se tornarem sociedades empresárias, já que neles é fácil perceber a presença do chamado elemento de empresa (organização dos fatores de produção), além de a prestação dos serviços se tornar altamente 'impessoalizada'. Afinal, qual seria a diferença deles para grandes hospitais dirigidos por médicos ou grandes escolas dirigidas por professores?

Analisando questões relacionadas ao direito tributário, o Superior Tribunal de Justiça já afirmou que as sociedades de advogados ostentam 'índole empresarial', não se distinguindo, no plano fático, das demais sociedades prestadoras de serviços constituídas por outros profissionais liberais. Confira-se:

Tributário. Contribuições ao SESC e ao SENAC. Empresa prestadora de serviços advocatícios. Art. 577 da CLT. Enquadramento sindical. Vinculação à Confederação Nacional do Comércio. Matéria pacificada. 1. As empresas prestadoras de serviços advocatícios são estabelecimentos de índole empresarial, por exercerem atividade econômica organizada com fins lucrativos, estando enquadradas na classificação do artigo 577 da CLT e seu anexo, e por conseguinte, vinculados à Confederação Nacional do Comércio. Desta forma, sujeitam-se à incidência das contribuições instituídas pelo art. $3^{\circ}$. do DL 9.853/46, bem como pelo art. $4^{o}$. Do DL 8.621/46 (Precedentes

\footnotetext{
${ }^{30}$ BORBA, 2012, p. 24.
} 
Jurisprudenciais). (...) (AgRg no Ag 518.309PR, Rel. Min. Teori Albino Zavascki, 1'. Turma, j. 16.12.2003, DJ 02.02.2004, p. 278).

Assim, entendo que as regras dos arts. 15 a17 da Lei 8.906/1994 configuraram uma clara exceção à regra do art. 966, parágrafo único, do Código Civil. Tais regras continuam em vigor, mesmo após a edição do Código, que é lei posterior, em razão da sua especialidade. Mas é de se pensar se não caberia ao legislador reformar a lei para adaptá-la aos ditames do novo Código ${ }^{31}$.

Vale dizer, porém, que inspirada na Lei 12.441/2011 que criou a EIRELI, a Lei 13.247/2016 alterou o Estatuto da OAB (Lei 8.906/1994), e permitiu a criação da "sociedade unipessoal de advogado". Logo, isso permitiu à sociedade unipessoal de advogado aderir ao Simples Nacional (regime tributário diferenciado, simplificado e favorecido previsto na Lei Complementar $n^{\circ}$ 123/2006). Os advogados não puderam à época se beneficiar da lei que criou a EIRELI porque o Estatuto da OAB expressamente vedava sociedade de um só advogado. Esta mudança é benéfica ainda porque a prática apontou que pequenas e médias empresas preferem a contratação de pessoas jurídicas para lidarem com as suas questões jurídicas, de modo a emitir notas fiscais e prestar contas, o que não seria possível na informalidade. Destaco abaixo dois artigos relevantes da referida lei que alterou o Estatuto da OAB:

Art. $2^{\circ}$ Os arts. 15, 16 e 17 da Lei no 8.906, de 4 de julho de 1994 - Estatuto da Advocacia, passam a vigorar com as seguintes alterações: "Art. 15. Os advogados podem reunir-se em sociedade simples de prestação de serviços de advocacia ou constituir sociedade unipessoal de advocacia, na forma disciplinada nesta Lei e no regulamento geral.

$\S 1^{\circ}$ A sociedade de advogados e a sociedade unipessoal de advocacia adquirem personalidade jurídica com o registro aprovado dos seus atos constitutivos no Conselho Seccional da OAB em cuja base territorial tiver sede.

$\S 2^{\circ}$ Aplica-se à sociedade de advogados e à sociedade unipessoal de advocacia o Código de Ética e Disciplina, no que couber.

\section{$[\ldots]$}

$\S 4^{\circ}$ Nenhum advogado pode integrar mais de uma sociedade de advogados, constituir mais de uma sociedade unipessoal de advocacia, ou integrar,

\footnotetext{
${ }^{31}$ RAMOS, 2016, p. $94-95$.
} 
simultaneamente, uma sociedade de advogados e uma sociedade unipessoal de advocacia, com sede ou filial na mesma área territorial do respectivo Conselho Seccional.

$\S 5^{\circ} \mathrm{O}$ ato de constituição de filial deve ser averbado no registro da sociedade e arquivado no Conselho Seccional onde se instalar, ficando os sócios, inclusive o titular da sociedade unipessoal de advocacia, obrigados à inscrição suplementar.

$\S 7^{\circ}$ A sociedade unipessoal de advocacia pode resultar da concentração por um advogado das quotas de uma sociedade de advogados, independentemente das razões que motivaram tal concentração." (NR)

"Art. 16. Não são admitidas a registro nem podem funcionar todas as espécies de sociedades de advogados que apresentem forma ou características de sociedade empresária, que adotem denominação de fantasia, que realizem atividades estranhas à advocacia, que incluam como sócio ou titular de sociedade unipessoal de advocacia pessoa não inscrita como advogado ou totalmente proibida de $\operatorname{advogar}^{32}$.

Outra restrição importante trata das cooperativas, que por expressa disposição legal serão sempre sociedades simples e, portanto, não empresárias. O Art. 982 do Código Civil, em seu Parágrafo Único, faz uma restrição expressa nesse sentido, afirmando que as sociedades por ações serão sempre empresárias e as cooperativas serão sempre simples. Conforme o caput, salvo exceções expressas, as atividades das demais sociedades que não as de cooperativa ou de sociedades por ações, se empresárias, serão consideradas empresárias, caso contrário, serão simples.

Art. 982. Salvo as exceções expressas, considera-se empresária a sociedade que tem por objeto o exercício de atividade própria de empresário sujeito a registro (art. 967); e, simples, as demais.

Parágrafo único. Independentemente de seu objeto, considera-se empresária a sociedade por ações; e, simples, a cooperativa.

Outra exceção ao que se categoriza por atividade empresária são os empresários rurais, que de acordo com o Código Civil de 2002, legislação vigente, podem desempenhar atividades empresárias se registrados no

\footnotetext{
${ }^{32}$ Disponível em: <http://www.oabsp.org.br/noticias/2016/01/apos-longa-batalha-figura-dasociedade-unipessoal-e-criada-no-pais.10596>. Acesso em: 15 mai. 2017.
} 
Registro Público de Empresas Mercantis. Esse tema é recorrente dentre os doutrinadores tradicionais por conta dessa faculdade incomum de registro, mas em grande medida porque o Projeto de Código de Obrigações de 1965 trazia o conceito de empresário rural e o excluía da classificação de empresário comercial, o classificando como empresário civil. Essa diferenciação não mais existe, mas como dito, é contada nos livros tradicionais de doutrina, conforme consta da obra de Rubens Requião (vide abaixo):

[...] O empresário dispensado de registro obrigatório é precisamente o que, no Projeto de Código de Obrigações de 1965, foi tratado de empresário civil, isto é, o empresário rural. O art. 971 do Código Civil não traz o conceito de empresário rural, como o fazia o art. 107 do Projeto no. 634/75. A noção deste terá que ser fixada pela doutrina. $\mathrm{O}$ art. 971 apenas faculta ao empresário rural a inscrição no registro público de empresas mercantis, fato que o equiparará, para todos os efeitos, ao empresário sujeito a registro ${ }^{33}$.

José Edwaldo Tavares Borba trata também dos empresários rurais:

Com relação ao empresário rural, a solução adotada pelo legislador foi singularíssima, tanto que, por um lado, permitiu a sua exclusão à condição de empresário (art. 970), e, por outro, permitiu que esse empresário rural, mediante registro na Junta Comercial (art. 971), adquirisse a qualificação plena de empresário.

A sociedade com atividade rural, se não for empresária - vale dizer, se não contar com uma organização -, será necessariamente uma sociedade simples. Dotada de organização, poderá optar, livremente, entre a condição de sociedade simples e a condição de sociedade empresária.

$[\ldots]$

A sociedade rural desfruta de uma situação especial. Mesmo sendo uma empresa, cabe-lhe escolher o seu status jurídico, de sociedade simples ou empresária, para tanto bastando optar, respectivamente, pelo Registro Civil das Pessoas Jurídicas ou pelo Registro Público de Empresas Mercantis.

[...] A empresa rural pode preferir o status de sociedade simples e, como consequência, não se sujeitar à lei de falências e recuperação, nem a processos mais rigorosos de escrituração contábil ${ }^{34}$.

Vale ressaltar que apesar de não ser tema deste projeto a análise do empresário como trabalhador autônomo, que é protegido pelo Direito do Trabalho por sua condição de hipossuficiência, os conceitos se

${ }^{33}$ REQUIÃO, 2012, p. 112.

${ }^{34}$ BORBA, 2012, p. 20. 
correlacionam, e duas caraterísticas dos trabalhadores autônomos são necessariamente compartilhadas pelos empresários, ou pelos Autônomos, aqui definidos: a não subordinação e a não pessoalidade. $\mathrm{O}$ autor trabalhista Maurício Godinho Delgado traz essas características e ainda trata da atividade empresarial para o desempenho da atividade autônoma:

[...] Noutras palavras, o trabalhador autônomo distingue-se do empregado, quer em face da ausência da subordinação ao tomador dos serviços no contexto da prestação do trabalho, quer em face de também, em acréscimo, poder faltar em seu vínculo com o tomador o elemento da pessoalidade.

A diferenciação central entre as figuras situa-se, porém, repita-se, na subordinação. Fundamentalmente, trabalho autônomo é aquele que se realiza sem subordinação do trabalhador ao tomador dos serviços. Autonomia é conceito antitético ao de subordinação. Enquanto esta traduz a circunstância juridicamente assentada de que o trabalhador acolhe a direção empresarial no tocante ao modo de concretização cotidiana de seus serviços, a autonomia traduz a noção de que o próprio prestador é que estabelece e concretiza, cotidianamente, a forma de realização dos serviços que pactuou prestar. $\mathrm{Na}$ subordinação, a direção central do modo cotidiano de prestação de serviços transfere-se ao tomador; na autonomia, a direção central do modo cotidiano de prestação de serviços preserva-se com o prestador de trabalho ${ }^{35}$.

Trago tal analogia apenas para retratar a independência do empresário, a autonomia para definir as diretrizes do negócio, definir a forma de circulação de bens ou prestação de serviços. O empresário ganha flexibilidade e independência, mas em contrapartida arca com os riscos do negócio. Desta definição partimos então a críticas objetivas de pontos específicos de normas que regem os Autônomos.

Conclui-se, portanto, deste subcapítulo, que quando me refiro a "Autônomo" trato de EI, MEI e EIRELI - tratando ainda neste trabalho de alguns de seus possíveis enquadramentos tributários - devido a uma escolha de campo de estudo privilegiando uma tendência contemporânea de empreendedorismo, por uma ótica empresária.

\footnotetext{
${ }^{35}$ DELGADO, Mauricio Godinho. Curso de direito do trabalho. $11^{\mathrm{a}}$ ed. São Paulo: LTr, 2012. p. 336.
} 


\title{
CAPÍTULO 2 - EMPRESÁRIO INDIVIDUAL
}

\subsection{O Porquê da Existência do EI}

Apesar de já definido anteriormente, para fins de introdução deste capítulo, trago abaixo conceito conciso da Junta Comercial do Estado do Espírito Santo (JUCEES) de quem é o Empresário Individual:

\begin{abstract}
Empresário Individual é a pessoa física que exerce profissionalmente atividade econômica organizada para a produção ou a circulação de bens ou serviços. Exerce a atividade por meio de uma firma, formada por seu nome civil. Para dar nome à empresa, poderá indicar seu nome completo ou abreviado, acrescentando, se preferir, designação mais precisa da sua pessoa ou do gênero de atividade. Exemplo: Um empresário com o nome civil de João Pedro Barbosa, por exemplo, poderá adotar um dos seguintes nomes empresariais: João Pedro Barbosa, J. Pedro Barbosa ou João P. Barbosa- Pedrinho. Se optar por incluir designação da atividade empresarial que irá desenvolver, a denominação pode ser 'João Pedro Barbosa- BAR'.
\end{abstract}

O Empresário individual responderá com seu patrimônio pessoal pelas obrigações contraídas por sua empresa. Para inscrever-se, a pessoa deverá ter mais de 18 anos ou ser emancipada. Sendo que, a empresa não poderá ser transferida para outro titular, a não ser em caso de falecimento ou autorização judicial ${ }^{36}$.

Uma pergunta que poderia advir dessa conceituação é: o que levaria empresários brasileiros a escolherem esta modalidade empresária, que consta do Código Civil? A questão é que muitos desses empresários atuavam na informalidade, mas clientes lhes pediam que emitissem notas fiscais, o que requeria que se regularizassem. A partir do registro na Junta Comercial é gerado um número no Cadastro Nacional de Pessoas Jurídicas da Secretaria da Receita Federal do Brasil (CNPJ), o que permite não apenas a emissão de notas fiscais, como a abertura de conta em banco na condição de pessoa jurídica; lhe permite solicitar empréstimos em nome da empresa; e participar em concorrência para venda de produtos ou prestação

\footnotetext{
${ }^{36}$ Disponível em: <https://www.jucees.es.gov.br/empresario-individual-constituicao/>. Acesso em: 11 mai. 2017.
} 
de serviços para órgãos governamentais. Ser EI parece vantajoso na medida que não se requer sócio, nem capital mínimo para abertura ${ }^{37}$.

É importante ressaltar que o ordenamento brasileiro só admite dois tipos de sociedades unipessoais (salvo sociedade unipessoal de advocacia já destacada neste texto): a subsidiária integral, criada em 1976 e ainda em vigor (prevista nos Arts. 251, 252 e 253 da Lei 6404/1976) - uma sociedade anônima unipessoal ${ }^{38}$, estrutura que só pode ser constituída por outra sociedade brasileira -, e a EIRELI - criada em 2011 pela Lei 12.441 e já definida anteriormente neste trabalho. O MEI, por sua vez, for apenas criado em 2008 pela Lei Complementar 128. Logo, considerando que as figuras (à exceção a subsidiária integral que não resolve a questão) são um tanto quanto recentes, no passado o Empresário Individual era a única opção.

Outro ponto mais recente vantajoso do EI é a possibilidade de enquadramento tributário como Microempresa ou Empresa de Pequeno Porte que a Lei Complementar 123/2006, hoje em vigor, herdou da Lei 9.841/1999. Tecerei comentários acerca destas modalidades mais adiante em outro capítulo, mas permitiram a inserção do EI no regime do Simples Nacional (com as devidas ressalvas).

Conclui-se que o Empresário Individual existe para atender a demanda prática de empresários para que tenham acesso a certos benefícios de uma empresa. Contudo, no mundo contemporâneo as demandas se tornaram mais complexas do que as soluções propostas pelo EI, o que enseja as críticas do subcapítulo a seguir.

\footnotetext{
${ }^{37}$ Disponível em: <https://www.jornalcontabil.com.br/conheca-diferencas-entre-mei-ei-e-eirelipara-abrir-uma-empresa-sem-socio/>. Acesso em: 14 mai. 2017.

${ }^{38}$ Disponível em:

<http://www.lex.com.br/doutrina_26983953_A_SOCIEDADE_UNIPESSOAL_NO_DIREITO_B

RASILEIRO.aspx>. Acesso em: 15 mai. 2017.
} 


\subsection{Crítica ao Instituto do EI}

Apesar dos pontos expostos acima, que dão sentido à existência do EI, se faz necessário dizer que Empresário Individual é uma modalidade que tende a se extinguir na prática empresarial brasileira, por motivo já apontado no subcapítulo anterior: a falta de limitação de responsabilidade do empresário. Esta questão já é uma realidade nas estatísticas do DREI, em reunião dos dados de registro das Juntas Comerciais de todo o Brasil, que apontaram que em 2016, 204.987 EIs foram extintos frente a 154.098 constituídos, já em 2017 de janeiro a março, já se somam 53.294 extintos e 39.232 constituídos $^{39}$. Nas palavras de Rubens Requião, em trecho já trazido neste trabalho:

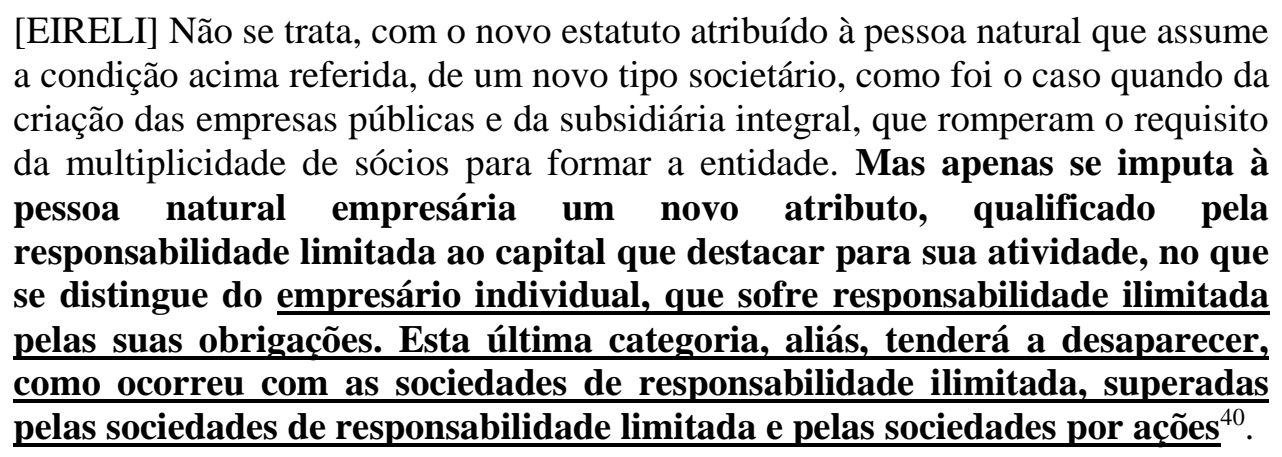

$\mathrm{O}$ fato é que o EI possui CNPJ, mas não possui personalidade jurídica e, portanto, não está sujeito à limitação de responsabilidade, respondendo o EI na integralidade dos bens pessoais do empresário pelas obrigações contraídas pela empresa. Responde ainda de forma direta, ou seja, os bens pessoais não respondem subsidiariamente pelas obrigações da empresa, apesar de haver entendimento da jurisprudência em sentido contrário, conforme explica o Doutor André Luiz Santa Cruz Ramos:

A grande diferença entre o empresário individual e a sociedade empresária é que
esta, por ser uma pessoa jurídica, tem patrimônio próprio, distinto do patrimônio
dos sócios que a integram. Assim, os bens particulares dos sócios, em princípio,
não podem ser executados por dívidas da sociedade, senão depois de executados
os bens sociais (nesse sentido, confira-se o disposto no art. 1.024 do Código

${ }^{39}$ Somatório dos dados. Disponível em: <http://drei.smpe.gov.br/assuntos/estatisticas/relatoriomensal>. Acesso em: 19 mai. 2017.

${ }^{40}$ REQUIÃO, 2012, p. 113. 
Civil). O empresário individual, por sua vez, não goza dessa separação patrimonial, respondendo com todos os seus bens, inclusive os pessoais, pelo risco do empreendimento. Sendo assim, pode-se concluir que a responsabilidade dos sócios de uma sociedade empresária é subsidiária (já que primeiro devem ser executados os bens da própria sociedade), enquanto a responsabilidade do empresário individual é direta.

A respeito do assunto, foi aprovado o Enunciado $n^{\circ} 5$ da I Jornada de Direito Comercial do CJF, com o seguinte teor: "Quanto às obrigações decorrentes de sua atividade, o empresário individual tipificado no art. 966 do Código Civil responderá primeiramente com os bens vinculados à exploração de sua atividade econômica, nos termos do art. 1.024 do Código Civil". Por mais que eu possa ter simpatia pelo referido enunciado, é preciso destacar que ele é absolutamente contra legem. $\mathrm{O}$ art. 1.024 do CC é uma regra específica para as sociedades.

\section{$[\ldots]$}

Já o empresário individual, em nosso ordenamento jurídico, além de responder diretamente com todos os seus bens pelas dívidas contraídas no exercício de atividade econômica (inclusive seus bens pessoais), não goza da prerrogativa de limitação de responsabilidade.

Portanto, enquanto a responsabilidade do empresário individual é direta e ilimitada, a responsabilidade do sócio de uma sociedade empresária é subsidiária (seus bens só podem ser executados após a execução dos bens sociais) e pode ser limitada, a depender do tipo societário utilizado ${ }^{41}$.

A responsabilidade ilimitada do EI tem origem na ideia de que o comerciante responder com a totalidade dos bens asseguraria segurança jurídica aos credores e imporia dever de cautela na gestão do negócio pelo comerciante, uma vez que a responsabilidade seria maior, conforme trata Marcela Maffei Quadra Travassos:

Principalmente em relação ao antigo comerciante, partia-se da premissa de que, com a responsabilidade ilimitada e o comportamento integral de seu patrimônio pelos resultados da atividade, restaria assegurada a segurança jurídica daqueles que com ele contratassem. Além disso, a ilimitação de responsabilidade imporia ao comerciante a necessidade de adotar maior cautela na gestão da atividade, em razão de enorme risco patrimonial a que estava sujeito, pois, caso se aventurasse de forma inconsequente na administração de seu negócio, estaria arruinado e verdadeiramente ameaçado de perder tudo ${ }^{42}$.

Contudo, essa discussão já foi há muito superada em países da Europa, sendo o Principado de Liechtenstein, em 1926, a primeira região da

\footnotetext{
${ }^{41}$ RAMOS, 2016, p. 77.

${ }^{42}$ TRAVASSOS, 2015, p. 41-42.
} 
Europa a implementar a sociedade limitada unipessoal e a limitação de responsabilidade se consolidou pela Europa em 1989. Entendeu-se que ao contrário de um meio para ocultar o patrimônio, a limitação de responsabilidade era um meio de segregação dos riscos empresariais, conforme versa Fábio Ulhôa Coelho:

O primeiro país a introduzir a sociedade unipessoal em seu direito foi o Principado de Liechtenstein, em 1926. A inovação foi associada, à época, a objetivos um tanto escusos, de planejamento tributário ou ocultação de patrimônio ou receitas. Parte do preconceito deveu-se à estranheza que a figura despertou: afinal, se a sociedade era resultante de contrato entre duas ou mais pessoas, para a realização de objetivos comuns, como poderia decorrer de declaração unilateral de um único sócio?

Com o tempo, este preconceito esvaneceu-se. A doutrina jurídica evoluiu, no sentido de perceber que a unipessoalidade não era incompatível com a noção de contrato social. Como mostra CALIXTO SALOMÃO FILHO, à medida que se redefinem os conceitos de contratos associativos e de permuta, em torno dos respectivos núcleos funcionais, a questão da contratualidade da sociedade unipessoal se resolve. Em outros termos, sendo a função dos contratos associativos a criação de uma organização, tanto a sociedade pluripessoal como a unipessoal derivam de negócios jurídicos desta espécie (1). Apontar o caráter contratual da sociedade como dificuldade à admissão da unipessoalidade originária, como parece a certa doutrina (2), é, a rigor, um falso problema.

Mas a associação inicial ao tratamento tributário mais benéfico, com que Liechtenstein (e outros estados, acunhados de "paraísos fiscais") procurava atrair investimentos estrangeiros, representou certo estigma para a sociedade limitada unipessoal (3). Em 1973, já liberto desta incômoda marca de origem, o instituto foi adotado pela Dinamarca; nos anos 1980, pela Alemanha, França, Holanda e Bélgica. Em 1989, a $12^{a}$ Diretiva da Comunidade Econômica Europeia, sobre sociedade, norteou os estados-membros quanto à incorporação da sociedade limitada unipessoal aos seus direitos. A partir de então, ela se difundiu, e foi introduzida em Portugal, Espanha, Itália, Luxemburgo, Reino Unido e Grécia. Assim, diversos países passaram a disciplinar institutos de limitação da responsabilidade do empresário individual; alguns deles valendo-se da solução societária, isto é, da figura da sociedade unipessoal. A referida Diretiva da CEE, cujo objetivo principal foi o de estimular a pequena e média empresa, destacou a solução societária entre os institutos jurídicos de segregação de riscos do empresário individual ${ }^{43}$.

Essa discussão, porém, remonta a muito antes, com os comerciantes na Idade Média que visavam resguardar seu patrimônio pessoal e o surgimento do embrião das sociedades anônimas com a Companhia das

\footnotetext{
${ }^{43}$ Disponível em: <http://www.lex.com.br/doutrina_26983953_A_SOCIEDADE_UNIPESSOAL_NO_DIREITO_B RASILEIRO.aspx>. Acesso em: 15 mai. 2017.
} 
Índias Orientais, o que não resolveu os problemas dos empreendedores que desejam limitar a sua responsabilidade ao exercer atividade pessoal e isoladamente. Marcela Maffei Quadra Travassos trata desta questão:

\begin{abstract}
Não por outro motivo, desde as primeiras estruturas de organização jurídica voltadas à exploração de atividades mercantis, que remontam à Idade Média, os comerciantes reclamavam pela validação de algum mecanismo de limitação da responsabilidade, capaz de servir de elemento concreto de balizamento dos riscos patrimoniais do negócio e de lhes resguardar, ainda que parcialmente, dos prejuízos decorrentes da atividade eventualmente malsucedida, ainda que conduzida de boa-fé e mediante emprego dos melhores esforços em busca do sucesso.
\end{abstract}

Assim, surgiram as primeiras formas societárias mais robustas com características próprias à limitação de responsabilidade. As Companhias das Índias Orientais, surgidas, ao tempo das grandes navegações, na Holanda, em 1602, são doutrinariamente citadas como exemplos dos primeiros ensaios desse movimento e tratadas por muitos autores como o berço da estrutura das sociedades anônimas, em que a divisão do capital em ações e a limitação de responsabilidade dos acionistas são pilares fundamentais.

Tal fenômeno, contudo, não foi suficiente para atender às demandas dos diversos empreendedores que desejavam exercer, pessoal e isoladamente, determinada atividade econômica, mercantil ou não. As sociedades foram estruturadas sob o primado da pluralidade de membros, o que impedia, concretamente, que os comerciantes individuais e os profissionais liberais autônomos, de uma maneira geral, pudessem individualmente se valer das formas societárias dotadas de regras de limitação de responsabilidade de seus membros ${ }^{44}$.

No Brasil hoje existe a figura da EIRELI para de algum modo responder ao clamor pela limitação de responsabilidade, contudo, não resolve a questão por completo, uma vez que a EIRELI possui limitações que serão tratadas mais adiante, mas que pode sim ser um dos motivos para o desaparecimento do instituto do EI. O fato de inexistir soluções de limitação de responsabilidade para empresários individuais ainda é um vácuo gravíssimo no ordenamento brasileiro, uma vez que isso dificulta que o empresário mensure os riscos da atividade, desestimulando a atividade empresária. A atividade empresária deve ser, pelo contrário, impulsionada para que gere empregos e movimente a economia. Riscos imensuráveis só favorecem a informalidade.

\footnotetext{
${ }^{44}$ TRAVASSOS, 2015, p. 43-44.
} 
Nas palavras de Marcela Maffei Quadra Travassos:

Diante da impossibilidade de medir os riscos empresariais do negócio, muitos empreendedores optaram pela informalidade ou pela criação de sociedades fictícias (sociedades limitadas em sua maioria), com a presença de sócios de fachada, que nada tinham a ver com a atividade, apenas para suprir o requisito da pluralidade exigida pelo direito societário brasileiro e gozar de estruturas de limitação de responsabilidade disponíveis.

\section{$[\ldots]$}

Ocorre que, em verdade, as incessantes reivindicações em torno da limitação de responsabilidade do empresário individual não refletem uma preocupação egoísta ou escondem, como se costuma supor no Brasil, o interesse de fraudar seus credores. Não se quer 'tornar o empresário individual intocável ou, meramente, aumentar-lhe a possibilidade de ganho, limitando-lhe as perdas'.

Bem ao contrário, o que se pretende é estabelecer, jurídica e formalmente, uma forma de organização que permita ao empresário, através da mensuração dos riscos patrimoniais a que está se sujeitando na exploração de seu negócio, expandir seus investimentos, ampliar as fontes de emprego, baratear os custos do produto ou serviço final e, em especial, privilegiar o valor social de seu trabalho e sua dignidade ${ }^{45}$.

Ainda sobre a questão de que a limitação de responsabilidade do empreendedor individual poderia ser utilizada como possível artifício para burlar os credores, Marcela Travassos defende ainda que se deve levar em consideração que, a partir da separação patrimonial e limitação de responsabilidade, os credores profissionais passam a não mais concorrer com os profissionais, o que não deixa de ser uma vantagem ${ }^{46}$.

Finalmente conclui-se que, como dito anteriormente, o EI supre algumas demandas do empresariado, mas não o suficiente para garantir um ambiente favorável à escalabilidade dos negócios, o que aumenta a demanda dos empresários por figuras jurídicas alternativas.

\footnotetext{
${ }^{45}$ TRAVASSOS, 2015, p. 50-51.

${ }^{46}$ Ibid., p. 52.
} 


\section{CAPÍTULO 3 - MICROEMPREENDEDOR INDIVIDUAL}

\subsection{O Porquê da Existência do MEl}

Já tratei do motivo do surgimento do MEI anteriormente, esclarecendo a importância de retirar certas atividades da informalidade, e tal propósito consta da exposição de motivos no $n^{\circ} 13$ /MF/MDIC/MPS quando do encaminhamento de proposta de Medida Provisória que alterava a Lei no 8.212, de 24 de julho de 1991 no tocante à contribuição previdenciária do microempreendedor individual, apesar do enfoque no trabalhador:

A Lei Complementar no 128, de 19 de dezembro de 2008, criou condições especiais para que o trabalhador conhecido como 'informal' possa se tornar microempreendedor individual e, assim, passar a atuar como microempresário participante da chamada 'economia formal' ${ }^{47}$.

O surgimento do MEI permitiu a formalização de atividades que eram tradicionalmente informais, como por exemplo "pipoqueiro", "quitandeiro ambulante", "sorveteiro ambulante", "vendedor ambulante de produtos alimentícios", "churrasqueiro ambulante", assim como permitiu a formalização de atividades contemporâneas como "editor de vídeo", "DJ", "VJ", "comerciante de equipamentos e suprimentos de informática" e "operador de marketing direto", conforme consta do Anexo XIII da Resolução CGSN no 94, de 29 de novembro de $2011^{48}$.

A opção desses profissionais pelo MEI decorre de vantagem eminentemente tributária, uma vez que o recolhimento de grande número dos impostos devidos é único, em valor fixo e reduzido, conforme consta do Art. 18-A, $\S 3^{\circ}$, V da Lei 123/2006 (vide abaixo, alteração de valor do Art. 18-A, $\S 3^{\circ}, \mathrm{V}$ da lei em vacatio até $1^{\circ}$ de janeiro de 2018). Além disso, o

\footnotetext{
${ }^{47}$ Disponível em: <http://www.planalto.gov.br/ccivil_03/_ato2011-2014/2011/Exm/EMI-13-MFMDIC-MPS-Mpv529.htm>. Acesso em: 16 mai. 2017.

${ }^{48}$ Disponível em:

<http://www.portaldoempreendedor.gov.br/legislacao/resolucoes/arquivos/ANEXO_XIII.pdf>.

Acesso em: 16 mai. 2017.
} 
MEI é isento de IR, da CSLL, do IPI, da CPP (caso não possua empregado), do PIS e da COFINS ${ }^{49}$ e não é obrigado a possuir escrituração contábil, uma vez que é dispensado desta obrigação pelo Art. 97, §1 $1^{\circ}$ da Resolução do CGSN de no 94/2011. O lucro líquido obtido pelo MEI na operação do seu negócio é isento e não tributável no Imposto de Renda Pessoa Física (IRPF), no entanto, a parcela da receita bruta que pode ser considerada como lucro líquido, de acordo com o art. 14 da LC 123/2006 fica limitada aos percentuais previstos para o lucro presumido ${ }^{50}$. A Lei do Lucro Presumido $^{51}$, Lei 9.249 de 26 de Dezembro de 1995, estabelece em seu Art.15 que os percentuais de abatimento do cálculo para Imposto de Renda são: (i) $8 \%$ para comércio, indústria e transporte de carga; (ii) $16 \%$ para transporte de passageiros; e (iii) $32 \%$ para serviços em geral. Considera-se aqui que, de acordo com a Instrução Normativa RFB nº 1690, de 20 de fevereiro de 2017, o teto para dispensa da obrigatoriedade de Declaração de Ajuste Anual do Imposto de Renda Pessoa Física referente ao exercício de 2017 foi de $\mathrm{R} \$ 28.559,70$ (anual) para rendimentos tributáveis e $\mathrm{R} \$$ 40.000,00 para rendimentos isentos, não tributáveis ou tributados exclusivamente na fonte ${ }^{52}$, uma vez que o MEI deve apresentar Declaração de Ajuste Anual de Imposto de Renda Pessoa Física (IRPF). Apenas o lucro presumido é isento de tributação, se o lucro real foi superior aos percentuais indicados, a diferença está sujeita à tributação e deve ser incluída na ficha rendimentos tributáveis recebidos de pessoa jurídica ${ }^{53}$. Os valores de recolhimento mensal do MEI constam do artigo abaixo:

\footnotetext{
${ }^{49}$ ALEXANDRE, 2016, p. 659.

${ }^{50}$ Disponível em: <http://www.portaldoempreendedor.gov.br/perguntas-frequentes/duvidasrelacionadas-ao-microempreendedor-individual/impostos-das-nota-fiscal/o-microempreendedorindividual-deve-pagar-imposto-de-renda-pessoa-fisica-irpf $>$. Acesso em: 16 mai. 2017.

${ }^{51}$ Disponível em: <https://economia.uol.com.br/imposto-de-renda/noticias/redacao/2016/03/26/ir2016-microempreendedor-individual-sempre-precisa-declarar-imposto.htm>. Acesso em: 16 mai. 2017.

52 Disponível em:

<https://idg.receita.fazenda.gov.br/interface/cidadao/irpf/2017/apresentacao/obrigatoriedade>. Acesso em: 16 mai. 2017.

53 Disponível em: <http://epocanegocios.globo.com/colunas/Financas-de-Bolso/noticia/2017/03/ir2017-quem-e-mei-precisa-declarar-ir-em-algumas-situacoes-sim.html>. Acesso em: 16 mai. 2017.
} 
Art. 18-A. O Microempreendedor Individual - MEI poderá optar pelo recolhimento dos impostos e contribuições abrangidos pelo Simples Nacional em valores fixos mensais, independentemente da receita bruta por ele auferida no mês, na forma prevista neste artigo.

$[\ldots]$

§ 3ㅇNa vigência da opção pela sistemática de recolhimento prevista no caput deste artigo:

\section{[..]}

$\mathrm{V}$ - o MEI, com receita bruta anual igual ou inferior a $\mathrm{R} \$ 81.000,00$ (oitenta $\mathrm{e}$ um mil reais), recolherá, na forma regulamentada pelo Comitê Gestor, valor fixo mensal correspondente à soma das seguintes parcelas: (Redação dada pela Lei Complementar $\mathrm{n}^{\circ}$ 155, de 2016).

a) $\mathrm{R} \$ 45,65$ (quarenta e cinco reais e sessenta e cinco centavos), a título da contribuição prevista no inciso IV deste parágrafo;

b) $\mathrm{R} \$ 1,00$ (um real), a título do imposto referido no inciso VII do caput do art. 13 desta Lei Complementar, caso seja contribuinte do ICMS; e

c) $\mathrm{R} \$ 5,00$ (cinco reais), a título do imposto referido no inciso VIII do caput do art. 13 desta Lei Complementar, caso seja contribuinte do ISS;

Há ainda a vantagem previdenciária do recolhimento integrado da Contribuição para a Seguridade Social, nos termos do Art. 18-A, $3^{\circ}$, IV da

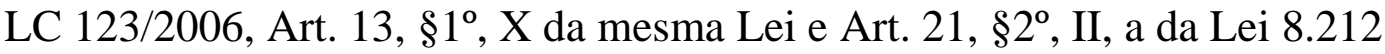
de 24 de julho de 1991, todos destacados abaixo:

Art. 13. O Simples Nacional implica o recolhimento mensal, mediante documento único de arrecadação, dos seguintes impostos e contribuições:

$$
[\ldots]
$$

$\S 1^{\circ} \mathrm{O}$ recolhimento na forma deste artigo não exclui a incidência dos seguintes impostos ou contribuições, devidos na qualidade de contribuinte ou responsável, em relação aos quais será observada a legislação aplicável às demais pessoas jurídicas:

$[\ldots]$

X - Contribuição para a Seguridade Social, relativa à pessoa do empresário, na qualidade de contribuinte individual; 


\section{$[\ldots]$}

Art. 18-A. O Microempreendedor Individual - MEI poderá optar pelo recolhimento dos impostos e contribuições abrangidos pelo Simples Nacional em valores fixos mensais, independentemente da receita bruta por ele auferida no mês, na forma prevista neste artigo.

$[\ldots]$

§ 3o Na vigência da opção pela sistemática de recolhimento prevista no caput deste artigo:

$[.$.

IV - a opção pelo enquadramento como Microempreendedor Individual importa opção pelo recolhimento da contribuição referida no inciso X do § 1o do art. 13 desta Lei Complementar na forma prevista no $\S 2^{\circ}$ do art. 21 da Lei ${ }^{\circ} 8.212$, de 24 de julho de 1991;

\section{LEI No 8.212, DE 24 DE JULHO DE 1991:}

Art. 21. A alíquota de contribuição dos segurados contribuinte individual e facultativo será de vinte por cento sobre o respectivo salário-de-contribuição. (Redação dada pela Lei no 9.876, de 1999).

$\S 2$ o No caso de opção pela exclusão do direito ao benefício de aposentadoria por tempo de contribuição, a alíquota de contribuição incidente sobre o limite mínimo mensal do salário de contribuição será de: (Redação dada pela Lei $n^{\circ} 12.470$, de 2011).

$[\ldots]$

II - 5\% (cinco por cento): (Incluído pela Lei nº 12.470, de 2011).

a) no caso do microempreendedor individual, de que trata o art. 18-A da Lei Complementar no 123, de 14 de dezembro de 2006; e (Incluído pela Lei $n^{\circ}$ 12.470, de 2011) (Produção de efeito).

O doutrinador Rubens Requião comenta acerca do quão favoráveis são os valores dos impostos pagos pelo MEI, lembrando que a figura tributária do microempreendedor individual surgiu da inclusão pela Lei Complementar no 128/2008 do Art. 18-A na Lei 123/2006: 
[...] O efeito central da nova figura é que o microempreendedor individual poderá optar pelo recolhimento dos impostos abrangidos pelo Simples Nacional, adotando-se valores fixos mensais, independentemente da receita bruta auferida no mesmo mês. Os valores são bastante módicos, como se vê do $\S 3^{\circ}, \mathrm{V}, a$, do art. 18-A. ${ }^{54}$.

Em grande parte das vezes, antes da figura do MEI, aqueles que não se formalizavam simplesmente sonegavam, caso contrário, desempenhando atividades econômicas como pessoa física, poderiam estar sujeitos à tabela de imposto de renda pessoa física, com alíquota que pode chegar a 27,5\%, conforme esclarece trecho abaixo de parecer encomendado por mim em agosto de 2016 ao escritório Touzon, Casemiro, Batalha \& Azevedo $\operatorname{Advogados}^{55}$, apesar de se tratar de consulta específica acerca de prestação de serviços com proventos advindos do exterior:

4) Pagamento pela pessoa natural (física)

Caso se opte pelo recebimento na pessoa física, devem ser analisados a incidência de IRPF, IOF, ISS.

Com relação ao IOF e o ISS, mais uma vez, o estudo precisa ser feito sob a perspectiva da exportação de serviços. Pelos motivos já expostos acima, o IOF está sujeito a alíquota zero. Já no que tange ao ISS, a Lei Complementar $n^{\circ}$ $116 / 2003$, que regulamenta nacionalmente esse imposto, determina no artigo $2^{\circ}$, I, que não incide ISS sobre a exportação de serviços.

Para o IRPF, caso só se tenha proventos advindos da prestação de serviço no exterior, haverá enquadramento na segunda faixa do IRPF. Assim, para um salário de R \$2.500,00 por mês, será aplicada alíquota de 7,5\% sobre aquilo que ultrapassar o valor isento de $\mathrm{R} \$ 1.903,98$. Portanto, pagar-se-ia $\mathrm{R} \$ 2.121,48$ de IRPF na declaração anual de IRPF.

Caso existam outras formas de renda por parte da pessoa física, é ncessário um olhar minudencioso na tabela do IRPF, abaixo, para que se identifique em que faixa seria feito o enquadramento, lembrando que a alíquota pode chegar até a $27,5 \%$.

\begin{tabular}{|c|c|c|}
\hline \hline Base de cálculo (R\$) & Alíquota $(\%)$ & Parcela a deduzir do IRPF (R\$) \\
\hline \hline Até $1.903,98$ & - & - \\
\hline \hline De $1.903,99$ até $2.826,65$ & 7,5 & 142,80 \\
\hline
\end{tabular}

\footnotetext{
${ }^{54}$ REQUIÃO, 2012, p. 91.

55 CORDEIRO, Adolpho Touzon D. et al. Contratação e pagamento por empresa no exterior; estrutura societária e tributária mais vantajosa. Parecer Técnico. ESCRITÓRIO TOUZON, CASEMIRO, BATALHA \& AZEVEDO ADVOGADOS. Ago. 2016.
} 


\begin{tabular}{|c|c|c|}
\hline \hline De $2.826,66$ até $3.751,05$ & 15 & 354,80 \\
\hline \hline De 3.751,06 até $4.664,68$ & 22,5 & 636,13 \\
\hline \hline Acima de $4.664,68$ & 27,5 & 869,36 \\
\hline
\end{tabular}

Vale ressaltar ainda a vantagem fiscal do MEI não ser obrigado a emitir nota fiscal quando seu cliente é pessoa física, devendo, contudo, emitir nota fiscal caso o cliente seja pessoa jurídica, a não sei que o destinatário tenha emitido nota fiscal de entrada, conforme Art. 97, II da Resolução do CGSN de nº 94/2011. O MEI também não é obrigado a emitir Nota Fiscal Eletrônica (NF-e), conforme Art. 97, §1º da referida Resolução do CGSN:

Art. 97. O MEI: (Lei Complementar no 123, de 2006, art. 26, §§ 1e e 6o-, inciso II)

II - em relação ao documento fiscal previsto no art. 57, ficará:

a) dispensado da emissão:

1. nas operações com venda de mercadorias ou prestações de serviços para consumidor final pessoa física;

2. nas operações com mercadorias para destinatário inscrito no CNPJ, quando o destinatário emitir nota fiscal de entrada;

b) obrigado à sua emissão:

1. nas prestações de serviços para tomador inscrito no CNPJ;

2. nas operações com mercadorias para destinatário inscrito no CNPJ, quando o destinatário não emitir nota fiscal de entrada.

§ 1ㅇ O MEI fica dispensado da escrituração dos livros fiscais e contábeis, da Declaração Eletrônica de Serviços e da emissão da Nota Fiscal Eletrônica (NFe), ressalvada a possibilidade de emissão facultativa disponibilizada pelo ente federado. (Lei Complementar no 123, de 2006, art. 2o-, inciso I e $\S 6$; ; art. 26, $\S$ $2-$ ).

Outra vantagem relevante do MEI é que lhe é facultado contratar empregado. A Lei Complementar 128/2008 incluiu o Art. 18-C na Lei Complementar $n^{\circ} 123 / 2006$, dispondo que a partir de então poderia se 
enquadrar como MEI o empresário individual que possuísse um único empregado que recebesse exclusivamente um salário mínimo ou o piso salarial da categoria profissional. E na leitura fria da lei, será permitido ao MEI contratar mais de um empregado a partir de 2018, pois a Lei Complementar $n^{\circ} 155 / 2016$ revogou o inciso IV do Art. 18-A, $\S^{\circ}$ da Lei Complementar $n^{\circ}$ 123/2006 que vedava a contratação de empregado por MEI e alterou a redação do Art. 18-C, não mais estabelecendo expressamente que ainda seria MEI aquele que contratasse um único empregado. Contudo, restringe-se essa condição ao empresário rural, uma vez que a LC 155/2016 altera o Art. 18-C da LC 123/2006 definindo que o empresário individual ou o empreendedor que exerça as atividades de industrialização, comercialização e prestação de serviços no âmbito rural pode ser $\mathrm{MEI}$, desde que possua um único empregado que receba exclusivamente um salário mínimo ou o piso salarial da categoria profissional.

Logo, o MEI é uma faculdade tributária deveras vantajosa para aqueles que se enquadram em seus requisitos, ou seja, empresários que possuem empreendimentos de porte reduzido, porém, como todo o instituto, não é perfeito, como veremos a seguir.

\subsection{Crítica ao Instituto do MEI}

Criticarei aqui alguns aspectos do MEI que dificultam ou prejudicam aqueles interessados em se tornar MEI: (i) falta de limitação de responsabilidade; (ii) obrigação acessória desnecessária de manter Relatório Mensal de Receitas Brutas; (iii) suposta desnecessidade de contador que na prática persiste; (iv) restrição de atividades; (v) retroatividade ao exceder receita bruta anual em mais de 20\%; e (vi) proporcionalidade de renda mensal quando do ingresso após o início do exercício.

Em relação ao item (i), como já esclarecido anteriormente, o MEI não é uma pessoa jurídica, mas apenas um enquadramento tributário do EI, 
logo, reforço o já discutido no capítulo anterior, em crítica à falta de limitação de responsabilidade do empresário individual, de modo a defender uma separação entre os bens pessoais do empresário e os bens da empresa.

Em relação ao item (ii) acima indicado, o Art. 97, I da Res. CGSN n ${ }^{\circ}$ 94/2011, transcrito abaixo, impõe como obrigação acessória ao MEI elaborar um Relatório Mensal de Receitas Brutas e o formulário para preenchimento é fornecido no Portal do Empreendedor. Essa obrigação não impõe que o relatório seja apresentado perante órgão algum, mas deve ser elaborado até o dia 20 de cada mês. O Sebrae afirma que o relatório mensal facilita a elaboração da Declaração Anual $^{56}$ (DASN-SIMEI) - que precisa ser submetida por meio do Portal do Empreendedor até o último dia de maio de cada ano $^{57}$ - uma vez que seria necessário apenas somar os valores dos Relatórios Mensais para se chegar aos dados da DASN-SIMEI. Ora, minha crítica aqui advém do fato de que o MEI está preocupado com trabalhar, com a operacionalização de seu negócio e qualquer obrigação acessória atrapalha o bom andamento da operação, pois deve o MEI parar seu labor para cumprir a exigência. Além disso, cada MEI já costuma ter uma forma própria de controlar os seus recebimentos, especialmente sabendo que terá de apresentar a DASN-SIMEI ao final do exercício. Adicionalmente, a lei não exigir a apresentação desse relatório perante órgão oficial traz o risco de três implicações: (a) caso não haja fiscalização - o que não deve, de forma alguma, haver porque oneraria desnecessária e demasiadamente a administração pública - o MEI não o elaborará, ignorando a disposição legal em conduta deliberadamente ilegal, e continuará a manter unicamente seu controle próprio como base para a Declaração Anual; (b) lhe tomará tempo de trabalho em que poderia estar produzindo para transcrever seu controle próprio para o relatório mensal

\footnotetext{
56 Disponível em: <https://www.sebrae.com.br/sites/PortalSebrae/ufs/ms/artigos/serie-mei-passoa-passo-para-elaboracao-do-relatoriomensal,a0a12bb750c04510VgnVCM1000004c00210aRCRD>. Acesso em: 16 mai. 2017.

${ }^{57}$ Art. 100 da Res. CGSN no 94/2011.
} 
determinado e futuramente para o DASN-SIMEI; ou (c) contratará um contador para fazê-lo, onerando ainda mais o MEI. Por esses motivos, defendo a extinção dessa obrigação.

Art. 97. O MEI: (Lei Complementar no 123, de 2006, art. 26, §§ 1ำ e 6o- inciso II)

I - fará a comprovação da receita bruta mediante apresentação do Relatório Mensal de Receitas Brutas de que trata o Anexo XII, que deverá ser preenchido até o dia 20 (vinte) do mês subsequente àquele em que houver sido auferida a receita bruta;

O ponto (iii) é para mim uma das críticas mais relevantes no que tange, na prática, o MEI. Como já dito no subcapítulo anterior, não se exige do MEI que promova escrituração contábil, logo, em tese não haveria a obrigatoriedade de contratação de contador, o que seria ótimo, um custo a menos para um empresário que apresenta baixo faturamento. Contudo, na prática, o sistema brasileiro é tão complexo que mesmo se o MEI conseguir encontrar e seguir o passo a passo do Sebrae, do Portal do Empreendedor ou serviços afins para montar o MEI sozinho, ele provavelmente ainda contrataria um contador para ajudá-lo a cumprir com a sua obrigação tributária de fazer a Declaração Anual de Ajuste de Imposto de Renda Pessoa Física, conforme regras também destacadas no subcapítulo anterior. Isto é uma verdade tão clara que o parecer no site do Senado que tratou da tramitação do projeto de lei que levou à edição da LC 128/2008 - já referenciada aqui e que trouxe mudanças profundas à LC 123/2006 destacava a importância da assistência contábil ao MEI:

Reveste-se de importância também a participação dos escritórios de serviços contábeis quanto à formalização do microempreendedor individual, auxiliando-o a cumprir com suas obrigações e garantindo-lhe os direitos correspondentes. Além disso, não se pode prescindir da participação dos escritórios de serviços contábeis nas pesquisas de campo e nas orientações adequadas a serem ministradas às empresas optantes pelo Simples Nacional ${ }^{58}$.

O Portal do Empreendedor, por sua vez, possui um link para os escritórios de contabilidade nos municípios (vide também abaixo). Minha

${ }^{58}$ Disponível em: <http://www25.senado.leg.br/web/atividade/materias/-/materia/87005>. Acesso em: 16 mai. 2017. 
crítica aqui se trata do fato de que a simplificação do sistema deveria ser verdadeira, na medida em que o MEI conseguisse sozinho lidar com todas as suas obrigações, mesmo que se trate do IRPF. E falo aqui especificamente do caso do MEI, mas em verdade, é evidentemente criticável que as pessoas físicas tenham, na prática, que contratar serviços contábeis para cumprir uma obrigação legal que é de todos que auferem renda, que é a declaração de imposto de renda.

13.11 - Quais os escritórios de contabilidade do meu município que atendem ao Microempreendedor Individual- MEI?

A relação de escritórios de contabilidade para atendimento ao MEI está disponível no Portal do Empreendedor. Para visualizar a relação, acesse o Portal Empreendedor no item "Onde Obter Ajuda" e depois clique em "Escritórios de Contabilidade para o MEI" Estes escritórios estão obrigados a efetuar, gratuitamente, a formalização do MEI e entrega da primeira declaração apenas ${ }^{59}$.

No entanto, é essencial dizer que o Art. 18, §22-B da LC 123/2006, leia-se abaixo, prevê que os escritórios de contabilidade são obrigados a oferecer atendimento contábil gratuito ao MEI relativo à sua inscrição como tal; à opção pelo recolhimento dos impostos e contribuições abrangidos pelo Simples Nacional em valores fixos mensais; e à primeira DASNSIMEI; sob pena de serem excluídos do Simples Nacional (§22-C). Contudo, minha crítica permanece, uma vez que: (a) essa informação em geral não chega ao MEI, que invariavelmente pagará um contador para fazê-lo; e (b) não cobre IRPF. Não que eu esteja aqui defendendo que os escritórios de contabilidade devem prestar mais serviços gratuitos, definitivamente não, mas defendo que os procedimentos deveriam sim ser mais simples, com manuais oficias objetivos e acessíveis, o que cortaria o gasto do empreendedor com contador ou o custo do contador de ser obrigado a prestar serviço gratuito para constituição de MEI. Vale dizer que em relação à divulgação de informações, o Sebrae foi realmente essencial para um avanço expressivo, mas ainda há muito o que ser feito e para a

59 Disponível em: <http://www.portaldoempreendedor.gov.br/perguntas-frequentes/duvidasrelacionadas-ao-microempreendedor-individual-1/13-2013-outros-assuntos $>$. Acesso em: 16 mai. 2017. 
maior eficiência dos institutos é necessário que sejam menos complexos e o IR é definitivamente um exemplo disso.

\begin{abstract}
Art. 18. O valor devido mensalmente pela microempresa ou empresa de pequeno porte optante pelo Simples Nacional será determinado mediante aplicação das alíquotas efetivas, calculadas a partir das alíquotas nominais constantes das tabelas dos Anexos I a V desta Lei Complementar, sobre a base de cálculo de que trata o $\S 3$ o deste artigo, observado o disposto no $\S 15$ do art. 3‥ (Redação dada pela Lei Complementar $n^{\circ} 155$, de 2016) Produção de efeito.
\end{abstract}

§ 22-B. Os escritórios de serviços contábeis, individualmente ou por meio de suas entidades representativas de classe, deverão:

I - promover atendimento gratuito relativo à inscricão, à opcão de que trata o art. 18-A desta Lei Complementar e à primeira declaracão anual simplificada da microempresa individual, podendo, para tanto, por meio de suas entidades representativas de classe, firmar convênios e acordos com a União, os Estados, o Distrito Federal e os Municípios, por intermédio dos seus órgãos vinculados;

$[\ldots]$

$\S 22$-C. Na hipótese de descumprimento das obrigações de que trata o $\S 22$-B deste artigo, o escritório será excluído do Simples Nacional, com efeitos a partir do mês subseqüente ao do descumprimento, na forma regulamentada pelo Comitê Gestor.

No que tange o ponto (iv), já me referi aqui inúmeras vezes ao Anexo XIII da Resolução do CGSN nº 94/2011 que lista as atividades que podem ensejar a criação de MEI. Essa limitação de atividades tem origem no Art. 18-A, $\S 4^{\circ}$-B da LC 123/2006 que prevê que: “O CGSN determinará as atividades autorizadas a optar pela sistemática de recolhimento de que trata este artigo, de forma a evitar a fragilização das relações de trabalho, bem como sobre a incidência do ICMS e do ISS.”. A tese de que a permissividade quanto às atividades de MEI geraria a precarização do trabalho é explicada e corroborada no livro do tributarista Ricardo Alexandre, conforme destacado abaixo, contudo, discordo dessa tese, uma vez que como o autor mesmo diz, o que indicará que há simulação, leia-se fraude à legislação trabalhista, é a verificação de todos os requisitos de 
caracterizam relação de emprego, quais sejam (a) não eventualidade; (b) subordinação; (c) pessoalidade; e (d) onerosidade. Logo, o legislador que listou as atividades permitidas ao MEI, como todo o ser humano, é acometido de racionalidade limitada e não terá como abarcar todas as atividades que tipicamente não se exercem nos meandros da relação de emprego e mesmo aquelas que geralmente se exercem dentro da relação de emprego, não necessariamente o são, então o legislador estaria deliberadamente excluindo esses profissionais dos benefícios do MEI.

Um possível problema decorrente da sistemática favorecida aplicável aos MEI seria a criação de um verdadeiro incentivo à nefasta prática brasileira segundo a qual pessoas jurídicas que querem reduzir seus encargos trabalhistas e previdenciários exigem que as pessoas físicas que lhe prestam serviços criem "empresas" para que estas (e não seus titulares) sejam contratadas. Tal forma de contratar pode ser considerada uma simulação nos casos em que se percebe que estão claramente presentes os elementos que caracterizam a relação de emprego, quais sejam: a não eventualidade (a necessidade é permanente e renovada), a subordinação hierárquica (dever de obediência), a pessoalidade (impossibilidade de substituição da pessoa física que presta o serviço), a onerosidade (existência de contraprestação de natureza salarial) e a assunção dos riscos da atividade econômica por quem admite, assalaria e dirige o empregado.

Visando a evitar o incremento deste tipo de contratação, a Lei Complementar 139/2011 acresceu ao art. 18-A da LC 123/2006 o § 4. ${ }^{\circ}$-B, estabelecendo que o CGSN determinará as atividades autorizadas a optar pela sistemática de recolhimento aplicável ao MEI, de forma a 'evitar a fragilização das relações de trabalho'. Assim, torna-se possível ao Comitê Gestor impedir que atividades tipicamente desenvolvidas dentro da relação de emprego sejam artificialmente prestadas por supostas 'empresas' em detrimento do direito de verdadeiros empregados travestidos de empresários ${ }^{60}$.

No que diz respeito ao ponto (v), o Art. 18-A, $\S 7^{\circ}$, III, $b$ da Lei 123/2006, transcrito abaixo, prevê que quando excedidos em mais de $20 \%$ a renda anual bruta máxima de $\mathrm{R} \$ 60.000,00$ até $1^{\circ}$ de janeiro de 2018 e $\mathrm{R} \$$ $81.000,00$ a partir de então, conforme Art. 18-A, $\S 1^{\circ}$. da Lei Complementar 123/2006 e alteração pela Lei Complementar 155/2016, com vacatio legis de outubro de 2016 a janeiro de 2018, haverá efeitos retroativos a $1^{\circ}$ de janeiro do ano calendário em que ocorreu o excesso. Apesar de expressa previsão legal, tal disposição parece ter caráter punitivo e não vejo porque

\footnotetext{
${ }^{60}$ ALEXANDRE, 2016, p. 660.
} 
um faturamento maior, que deveria ser estimulado pelo Direito para geração de emprego, renda e pagamento de mais impostos no futuro devido ao crescimento da empresa, fosse "punido" com retroatividade. Portanto, os efeitos mais defensáveis seriam os da alínea a para qualquer caso de superação da receita bruta anual para enquadramento como MEI (excluído o percentual):

Art. 18-A. O Microempreendedor Individual - MEI poderá optar pelo recolhimento dos impostos e contribuições abrangidos pelo Simples Nacional em valores fixos mensais, independentemente da receita bruta por ele auferida no mês, na forma prevista neste artigo.

$\S 1^{\circ}$ Para os efeitos desta Lei Complementar, considera-se MEI o empresário individual que se enquadre na definição do art. 966 da Lei $n^{\circ} 10.406$, de 10 de janeiro de 2002 - Código Civil, ou o empreendedor que exerça as atividades de industrialização, comercialização e prestação de serviços no âmbito rural, que tenha auferido receita bruta, no ano-calendário anterior, de até R\$ 81.000,00 (oitenta e um mil reais), que seja optante pelo Simples Nacional e que não esteja impedido de optar pela sistemática prevista neste artigo. (Redação dada pela Lei Complementar $\mathrm{n}^{\circ}$ 155, de 2016) Produção de efeito.

\section{$[\ldots]$}

$\S 7$ o O desenquadramento mediante comunicação do MEI à Secretaria da Receita Federal do Brasil - RFB dar-se-á:

$[\ldots]$

III - obrigatoriamente, quando o MEI exceder, no ano-calendário, o limite de receita bruta previsto no $\S 1^{\circ}$ - deste artigo, devendo a comunicação ser efetuada até o último dia útil do mês subseqüiente àquele em que ocorrido o excesso, produzindo efeitos:

a) a partir de 1 de janeiro do ano-calendário subseqüente ao da ocorrência do excesso, na hipótese de não ter ultrapassado o referido limite em mais de $20 \%$ (vinte por cento);

b) retroativamente a 1- de janeiro do ano-calendário da ocorrência do excesso, na hipótese de ter ultrapassado o referido limite em mais de $20 \%$ (vinte por cento);

Em uma leitura analógica, o já citado tributarista Ricardo Alexandre, ao tratar de empresa de pequeno porte, critica a retroatividade, apesar de não mencionar o $\S 10^{\circ}$ do Art. $3^{\circ}$ da Lei 123/2006 que prevê a 
retroatividade por força de rendimentos acima de $20 \%$ da limitação, o que enseja desenquadramento:

\begin{abstract}
Pela redação originária da LC 123/2006, caso o excesso não ocorresse no anocalendário de início de atividade, a exclusão se verificaria sem efeito retroativo, somente sujeitando a entidade excluída ao recolhimento individualizado dos tributos a partir do ano-calendário subsequente. Com o advento da LC 139/2011, a exclusão passa a ocorrer já no mês seguinte, salvo se o excesso verificado em relação à receita bruta não for superior a $20 \%$, hipótese em que os efeitos da exclusão permanecem se confirmados apenas a partir do ano-calendário subsequente (LC 123/2006, art. 3..$^{\circ}$, $\S 9 .^{\circ}$ e $9 .^{\circ}-\mathrm{A}$ ). De qualquer forma, mantém-se afastada a retroatividade, evitando-se uma verdadeira punição para a empresa que "cresceu" e deixou a condição de empresa de pequeno porte, algo que é desejável em uma economia capitalista ${ }^{61}$.
\end{abstract}

Vale ainda acrescentar que reputo por inconstitucional esta disposição, uma vez que a Constituição Federal prevê em seu Art. 174 que "Como agente normativo e regulador da atividade econômica, o Estado exercerá, na forma da lei, as funções de fiscalização, incentivo e planejamento, sendo este determinante para o setor público e indicativo para o setor privado.". Ou seja, é dever do Estado o estímulo ao crescimento econômico e a lei infraconstitucional em voga vai claramente em sentido contrário, desencorajando a atividade econômica ao dar caráter de retroatividade à norma quando da superação da receita bruta esperada, sendo que na faixa seguinte a arrecadação já será superior.

Por fim, em se tratando do ponto (vi), a discussão se correlaciona com o ponto anterior na medida em que trato novamente de hipótese de desenquadramento. A crítica à retroatividade subsiste, no entanto agora foca-se no Art. $18-\mathrm{A}, \S 7^{\circ}, \mathrm{IV}, b$ da Lei $123 / 2006$, dizendo respeito à limitação da receita bruta anual com base proporcional quando do ingresso no MEI após o início do ano calendário. O Art. $18-\mathrm{A}, \S 7^{\circ}$, IV da Lei 123/2006 prevê que o limite da receita bruta anual, nesse caso, corresponderá ao número de messes entre o ingresso e o fim do exercício multiplicado por $\mathrm{R} \$ 5.000,00$ até $1^{\circ}$ de janeiro de 2018 e $\mathrm{R} \$ 6.750,00$ a partir de então, devido à alteração do referido artigo pela LC 155/2016. A

\footnotetext{
${ }^{61}$ ALEXANDRE, 2016, p. 623.
} 
crítica neste ponto é unicamente pragmática, uma vez que a renda mensal de em empresário pode apresentar grandes flutuações, além de certa atividade poder ser sazonal, tendo momentos de pico em certas épocas do ano, o que por essa proporcionalidade poderia levar ao desenquadramento, caso o empresário constituísse a MEI durante seu período do ano de maior movimento.

Art. 18-A. O Microempreendedor Individual - MEI poderá optar pelo recolhimento dos impostos e contribuições abrangidos pelo Simples Nacional em valores fixos mensais, independentemente da receita bruta por ele auferida no mês, na forma prevista neste artigo.

$\S 2^{\circ}$ No caso de início de atividades, o limite de que trata o $\S 1^{\circ}$ será de $\mathrm{R} \$$ 6.750,00 (seis mil, setecentos e cinquenta reais) multiplicados pelo número de meses compreendido entre o início da atividade e o final do respectivo anocalendário, consideradas as frações de meses como um mês inteiro. (Redação dada pela Lei Complementar nº 155, de 2016) Produção de efeito

$\S 7^{\circ} \mathrm{O}$ desenquadramento mediante comunicação do MEI à Secretaria da Receita Federal do Brasil - RFB dar-se-á:

$[\ldots]$

IV - obrigatoriamente, quando o MEI exceder o limite de receita bruta previsto no $\S 2^{\circ}$ deste artigo, devendo a comunicação ser efetuada até o último dia útil do mês subseqüiente àquele em que ocorrido o excesso, produzindo efeitos:

a) a partir de $1^{\circ}$ de janeiro do ano-calendário subseqüente ao da ocorrência do excesso, na hipótese de não ter ultrapassado o referido limite em mais de $20 \%$ (vinte por cento);

b) retroativamente ao início de atividade, na hipótese de ter ultrapassado o referido limite em mais de $20 \%$ (vinte por cento).

O MEI é, portanto, enquadramento tributário largamente benéfico ao empresário, apenas destaquei certos regramentos legais do instituto que poderiam ser aprimorados. 


\section{CAPÍTULO 4 - EMPRESA INDIVIDUAL DE RESPONSABILIDADE LIMITADA}

\subsection{O Porquê da Existência da EIRELI}

Em capítulo anterior, em que define Autônomo, expliquei o que é a EIRELI e seu propósito de existência, mas venho neste capítulo reforçar a ideia de que a EIRELI veio como uma inovação necessária no direito brasileiro, permitindo uma sociedade unipessoal formada por pessoa natural ou jurídica, sem as exigências da subsidiária integral, que é uma sociedade anônima unipessoal, por assim dizer, ou seja, sem exigir uma estrutura complexa por trás.

A EIRELI foi uma solução legal para um problema prático evidente e sua criação permitiu a formalização de diversos negócios que antes, ou se mantinham na informalidade, ou se valiam de limitadas com sócios "fantasmas", ou sócios de fachada, que geralmente eram parentes ou amigos próximos que detinham uma parcela simbólica das quotas da empresa, unicamente para configurar a pluralidade de sócios que é requisito legal para a constituição de sociedade limitada (Art. 1033, IV, CC). Tal estrutura é ainda de interesse da administração pública porque a formalização de atividades pressupõe aumento na arrecadação, mesmo que sujeitos ao regime tributário mais favorável do Simples Nacional, conforme será tratado mais adiante. O doutrinador Rubens Requião deixa essa questão muito clara no trecho abaixo:

Atribui-se a criação do novo instituto a uma generosa iniciativa do legislador, interessado em regularizar a situação de milhões de profissionais que se mantinham à margem do sistema legal, por causa de dificuldades de toda ordem, sofrendo prejuízos pela clandestinidade, como falta de cobertura previdenciária, exposição a delitos tributários etc. Ou, ainda, para evitar a suposta sociedade de responsabilidade limitada formada com o auxílio de um sócio infimamente minoritário, sem qualquer participação ou interesse na sociedade, participando apenas para atender a pluralidade de sócios, como ocorre comumente com sociedade entre cônjuges. Não se pode desconsiderar, entretanto, e que é seguramente desejada pela administração pública, a outra faceta dessa suposta generosidade ou atenção e respeito à realidade social, 
que é o enquadramento do profissional na estrutura legal, o cadastramento fiscal, a tributação generalizada e inconsequente, apesar do regime mais racional implantado em favor da micro e pequena empresa. Os empresários individuais de responsabilidade limitada, uma vez registrados, passarão a contribuir para a previdência social, pagar imposto de renda, imposto sobre serviços etc ${ }^{62}$.

A respeito dos malefícios do 'sócio de fachada', tanto da inafastável ilegalidade, como do dispêndio das Juntas Comerciais com fiscalização e das lides levadas ao judiciário, trata o deputado Marcos Montes, em citação a artigo publicado na Gazeta Mercantil de 30 de junho de 2003, pág. 1 do caderno "Legal e Jurisprudência", sob o título "Sociedade limitada e a nova lei", de autoria do Prof. Guilherme Duque Estrada de Moraes, na justificação do PL 4605/2009, que com alterações diversas, se tornou a Lei 12.441/2011:

O fato é que uma grande parte das sociedades por quotas de responsabilidade limitada, designadas sociedades limitadas pelo novo Código Civil, foi constituída apenas para que se pudesse limitar a responsabilidade do empresário ao valor do capital da empresa. A rigor, o que existe, nesses casos, é uma 'sociedade faz-deconta': uma firma individual vestida com a roupagem de sociedade. Basta ver o número de sociedades em que um único sócio detém a quase totalidade do capital social ou em que os dois sócios são marido e mulher, casados em regime de comunhão universal de bens, situação que, aliás, poderá exigir grande número de alterações contratuais, já que o novo Código Civil não a admite.

$\mathrm{O}$ artifício de se criar uma 'sociedade-faz-de-conta' gera enorme burocracia, pois, além de tornar mais complexo o exame dos atos constitutivos, por parte das Juntas Comerciais, exige alterações nos contratos, também sujeitas a um exame mais apurado das Juntas, para uma série de atos relativos ao funcionamento da empresa. Além disso, causa, também amiúde, desnecessárias pendências judiciais, decorrentes de disputas com sócios que, embora com participação insignificante no capital da empresa, podem dificultar inúmeras operações ${ }^{63}$.

O deputado Marcos Montes afirma ainda na justificação do referido PL que a EIRELI aumentaria a arrecadação de impostos e formalizaria importante segmento de negócios que gera $80 \%$ dos empregos no país:

\footnotetext{
${ }^{62}$ REQUIÃO, 2012, p. 113-114.

${ }^{63}$ Disponível em:

<http://www.camara.gov.br/proposicoesWeb/prop_mostrarintegra;jsessionid=9F3DDED233B958 F9694BCA9BFC101710. proposicoesWebExterno1 ?codteor=631421\&filename=PL+4605/2009>. Acesso em: 25 mai. 2017.
} 
Diante desse disciplinamento legal, que ora propomos, acreditamos que o Estado terá grandes ganhos no aumento da arrecadação e a economia como um todo evoluirá com a formalização e melhor organização de um segmento importante dos negócios, que responde por mais de $80 \%$ da geração de empregos neste país, conforme dados do próprio SEBRAE ${ }^{64}$.

Vale lembrar ainda, e Requião ${ }^{65}$ também faz tal observação em sua obra, que a Lei $\mathrm{n}^{\mathrm{o}}$ 12.441/2011, que instituiu a EIRELI, ao alterar o Art. 1.033, CC, não apenas excluiu o requisito da multiplicidade de sócios, como permitiu que sociedades que tenham perdido a multiplicidade possam se tornar empresários individuais ou EIRELI, vide artigo transcrito abaixo:

Art. 1.033. Dissolve-se a sociedade quando ocorrer:

IV - a falta de pluralidade de sócios, não reconstituída no prazo de cento e oitenta dias;

Parágrafo único. Não se aplica o disposto no inciso IV caso o sócio remanescente, inclusive na hipótese de concentração de todas as cotas da sociedade sob sua titularidade, requeira, no Registro Público de Empresas Mercantis, a transformação do registro da sociedade para empresário individual ou para empresa individual de responsabilidade limitada, observado, no que couber, o disposto nos arts. 1.113 a 1.115 deste Código. (Redação dada pela Lei n ${ }^{\circ}$ 12.441, de 2011) (Vigência).

O grande desejo dos empresários por uma sociedade unipessoal, que os levava a utilizar-se de subterfúgios para se revestir de estrutura de sociedade, remete à crítica discorrida anteriormente neste trabalho a respeito do Empresário Individual. A personalidade jurídica, uma ficção jurídica que permite uma separação entre o patrimônio individual do empresário e o patrimônio da empresa, e uma consequente limitação de responsabilidade das obrigações da empresa ao patrimônio da mesma é o que atraía os empresários para as sociedades limitadas "fajutas" e o que os

\footnotetext{
${ }^{64}$ Disponível em:

<http://www.camara.gov.br/proposicoesWeb/prop_mostrarintegra;jsessionid=9F3DDED233B958 F9694BCA9BFC101710. proposicoesWebExterno1? codteor=631421\&filename=PL+4605/2009>. Acesso em: 25 mai. 2017.

${ }^{65}$ REQUIÃO, 2012, p. 117.
} 
atrai à EIRELI. Rubens Requião é novamente categórico acerca deste ponto:

[...] Esse aspecto, ao que nos parece, é o principal a ser extraído da formatação adotada pelo legislador, e absorve a especial característica da sociedade empresarial reconhecida como pessoa jurídica, que é a capacidade de contrair obrigações e direitos em nome próprio, e a autonomia patrimonial, pois seu patrimônio lhe pertence exclusivamente, impedindo, em suma, confusão com a pessoa natural do seu titular. O corolário é que não se pode atribuir dívidas da pessoa jurídica ao titular da empresa individual de responsabilidade limitada, nem as particularidades do titular poderão ser suportadas pela pessoa jurídica. De tudo resulta que a empresa individual de responsabilidade limitada poderá adquirir bens e direitos em nome próprio, sem que estes possam ser havidos como bens da pessoa natural do empresário. Bem assim poderá vende-los livremente, dispensada a outorga uxória ${ }^{66}$.

É necessário aqui fazer uma observação de que a constituição da EIRELI não afasta a chamada Teoria da Desconsideração ou disregard of legal entity, teoria que surgiu nos tribunais norte-americanos e importamos na forma do Art. 50, CC, de modo que se permite levantar o "véu da personalidade" jurídica e desconsiderar a personalidade jurídica em caso de abuso, desvio de finalidade e confusão patrimonial, de modo a atingir o patrimônio dos sócios, ou do único sócio, no caso da EIRELI. Há também largo entendimento jurisprudencial de desconsideração por dívida de natureza trabalhista. Não aprofundarei quanto a esse tema, pois não faz parte do escopo deste trabalho, mas os dois Enunciados de Jornadas de Direito Civil abaixo indicam o posicionamento da jurisprudência civilista a respeito dessa questão:

O Enunciado ${ }^{\circ} .51$ da Jornada de Direito Civil realizada no Superior Tribunal de Justiça assentou sobre a desconsideração tratada no art. 50 do Código Civil: 'a Teoria da desconsideração da personalidade jurídica disregard doctrine fica positivada no novo Código Civil, mantidos os parâmetros existentes nos microssistemas legais e na construção jurídica sobre o tema'. E mais: 'Só se aplica a desconsideração da personalidade jurídica quando houver a prática de ato irregular e, limitadamente, aos administradores ou sócios que nela hajam incorrido' (Enunciado n. 7 da Jornada do Superior Tribunal de Justiça) ${ }^{67}$.

\footnotetext{
${ }^{66}$ REQUIÃO, 2012, p. 115.

${ }^{67}$ Disponível em:

<http://www.ambitojuridico.com.br/site/?n_link=revista_artigos_leitura\&artigo_id=11744>.

Acesso em: 17 mai. 2017.
} 
Logo, como já problematizado em capítulo anterior, uma sociedade unipessoal nos termos da EIRELI é inédita no direito brasileiro e extremamente necessária. Um instituto importante como este tardou até 2011 para se concretizar e não se consolidou com a maior precisão técnica possível, conforme explicado no subcapítulo seguinte.

\subsection{Crítica ao Instituto da EIRELI}

Diante dos benefícios apontados no subcapítulo anterior, partamos agora a uma análise crítica do instituto. Considerando que já se discutiu a polêmica acerca da natureza jurídica da EIRELI, optei por concentrar a minha oposição em três previsões do Art. 980-A, CC, que possuem clara repercussão prática, são elas: (i) parâmetro excessivamente elevado e arbitrário de 100 salários mínimos de capital social mínimo; (ii) indexação do capital social de acordo com o salário mínimo, o que é inconstitucional; e (iii) limitação de uma EIRELI por pessoa natural.

Em relação ao primeiro ponto, a Lei 12.441/2011, que criou a figura da EIRELI, incluiu no Código Civil o seu atual art. 980-A, caput abaixo:

Art. 980-A. A empresa individual de responsabilidade limitada será constituída por uma única pessoa titular da totalidade do capital social, devidamente integralizado, que não será inferior a 100 (cem) vezes o maior saláriomínimo vigente no País. (Incluído pela Lei nº 12.441, de 2011) (Vigência).

A lei estabelece que para o surgimento da EIRELI é necessária a constituição e integralização de pronto de capital social não inferior a 100 vezes o salário mínimo. Sendo lógico, contudo, entender que vale o salário mínimo no ato da constituição do capital para que se ateste a capacidade da sociedade para início de sua atividade, não cabendo reajuste anual ${ }^{68}$. Esclareço aqui, primeiramente, o propósito do legislador com este requisito: evitar fraudes e garantir que o empresário possui um capital mínimo para a

\footnotetext{
${ }^{68}$ TRAVASSOS, 2015, p. 213.
} 
condução de seus negócios, conforme consta de trecho de justificativa do relator Marcelo Itagiba do PL 4605/2009 que deu origem à EIRELI:

\begin{abstract}
Registro, também, que, considerando que se faz conveniente delimitar, em proporção razoável, o porte da organização que se pode constituir como empesa individual, a fim de que não se desvirtue a iniciativa nem esta se preste a meio e ocasião para dissimular ou ocultar vínculo ou relacão diversa, propugnamos introduzir parâmetro mínimo apto a caracterizar a pessoa jurídica de que ora se trata, fazendo supor que se reúnem suficientes elementos de empresa, como sede instalada ou escritório, equipamentos etc., tal como se fez para caracterizar microempresas e o empresário individual, nas respectivas leis reguladoras.
\end{abstract}

Com este propósito, estabelecemos que o capital social não deva ser inferior ao equivalente a 100 salários mínimos, montante a partir do qual se tem por aceitável a configuração patrimonial da empresa individual. A tanto, emendamos a redação dada ao caput do art. 985-A proposto (art. 980-A), a ser aditado ao Código Civil por força do art. $2^{\circ}$ do Projeto ${ }^{69}$.

Marcela Maffei Quadra Travassos explicita a questão:

$\mathrm{Na}$ exigência de capital mínimo de 100 (cem) salários-mínimos e de integralização no ato de constituição, nota-se nítida motivação do legislador de conter a prática de eventuais abusos e fraudes na constituição de EIRELIs fictícias. É exigência específica deste tipo de sociedade e por isso merece destaque especial neste momento do trabalho ${ }^{70}$.

A grande questão reside no fato de que o legislador definiu um valor excessivamente elevado para um instituto que deveria vir ao auxílio de pequenos empresários, uma vez que tal valor, dependendo da atividade exercida, pode exceder em muito os ativos da empresa. A grande maioria das sociedades (exceto sociedades que desempenham atividades muito estratégicas e são reguladas em lei específica, como as instituições financeiras) não possuem sequer requisito de capital mínimo, que fará uma exigência de capital no montante de $\mathrm{R} \$ 93.700,00$, considerando o Decreto no. 8.948 de 29 de dezembro de 2016 que ajustou o salário mínimo a partir de $1^{\circ}$ de janeiro de 2017 para $\mathrm{R} \$ 937,00$. Tal disposição inviabiliza a constituição da EIRELI para alguns profissionais e favorece a manutenção de sociedades limitadas com sócios de fachada. A EIRELI deveria ter

\footnotetext{
${ }^{69}$ Disponível em: <www.camara.gov.br/sileg/integras/793401.pdf>. Acesso em: 27 mai. 2017.

70 TRAVASSOS, 2015, p. 163
} 
surgido como um meio de facilitar a atividade empresária e não coibir. Marcela Maffei Quadra Travassos, em obra publicada em 2015 (portanto valores da época), corrobora com essa tese, conforme indicado abaixo:

A primeira grande questão que se coloca em relação ao capital mínimo refere-se ao valor aleatoriamente previsto pelo legislador no montante de 100 (cem) vezes o maior salário mínimo vigente no país. Considera-se este valor demasiadamente exagerado e eventual óbice a que a EIRELI seja realmente adotada por pequenos e médios empresários como forma de organização jurídica para exploração de atividade econômica.

De fato, também parece que o montante de 100 (cem) vezes o maior salário mínimo vigente no país (aproximadamente $\mathrm{R} \$ 67.800,00$, considerando o salário mínimo federal atual conforme Decreto no. 7.872, de 26.12.2012) apresente-se ainda mais exagerado se confrontado com a realidade de que não se exige capital mínimo para a constituição das demais sociedades, salvo para algumas sociedades em razão da atividade, como as instituições financeiras, por exemplo, exigência esta que se verifica por força de legislação especial.

Infelizmente, continua neste cenário, sendo muito mais fácil constituir uma sociedade limitada fictícia, com um sócio de palha de participação irrelevante e ausente do dia a dia do negócio, em que o empresário individual de fato goze de limitação de responsabilidade e não tenha que cumprir a exigência de elevado capital mínimo integralizado no ato de constituição ${ }^{71}$.

Nesse sentido, a Ação Direta de Inconstitucionalidade, com pedido de medida cautelar, no. 4637/2011 foi proposta pelo Partido Popular Socialista - PPS e o requerente sustenta em sua petição inicial que o requisito de integralização de capital social no valor de 100 salários mínimos viola o princípio da livre iniciativa consagrado no Art. 170, CC, "uma vez que a exigência em questão representa um claro cerceamento à possibilidade de abertura de empresas individuais de responsabilidade limitada por pequenos empreendedores" ${ }^{2}$, motivo pelo qual pede medida cautelar. A petição inicial fala ainda de violação do princípio da isonomia, que denomina princípio da igualdade, uma vez que essa exigência de capital não existe para sociedades limitadas e diz que tal exigência inviabiliza a

\footnotetext{
71 TRAVASSOS, 2015, p. 210.

${ }^{72}$ AGU. Manifestação ADI no 4.637/2011. p 2. Disponível em:

<www.agu.gov.br/page/download/index/id/9460565>. Acesso em: 18 mai. 2017.
} 
opção por este tipo de sociedade pelo pequeno empreendedor. ${ }^{73}$ A petição alega ainda violação ao Art. 7, IV, CF, o que será tratado quando for discutido o ponto (ii). Marcela Maffei Quadra Travassos trata da referida ADI:

Em linha com esta crítica, deve-se mencionar que o Partido Popular Socialista (PPS) ingressou com a ADI $\mathrm{n}^{\circ} 4.637 / 2011$ no Supremo Tribunal Federal, alegando a inconstitucionalidade da exigência de capital mínimo em EIRELI no valor de 100 (cem) vezes o maior salário mínimo vigente no país, ao argumento de que 'a eventual constituição de pessoas jurídicas individuais de responsabilidade limitada por pequenos empreendedores, causando desnecessário embaraço a uma efetiva oportunidade de desenvolvimento econômico do país. $^{74}$.

Acrescenta-se ainda o PL 2468/2011, de autoria de Carlos Bezerra do PMDB/MT, que tramita na Câmara dos Deputados e encontra-se em aguardo de Relator na Comissão de Finanças e Tributação $(\mathrm{CFT})^{75}$, que, por sua vez, propõe a alteração desse requisito de 100 para 50 salários mínimos. Vale dizer, contudo, que o PL foi proposto em 2011, quando o salário mínimo ainda somava $\mathrm{R} \$ 545,00$. Exponho abaixo trecho da justificação:

A motivação dessa proposição partiu de uma crítica muito bem fundamentada pelo Dr. Cássio Cavalli, conceituado professor de direito da empresa da Escola de Direito da Fundação Getúlio Vargas, no Rio de Janeiro, a qual pedimos licença para reproduzir, com grifos e parcialmente, nesta justificação:

'(...) Agora, com a criação da Empresa Individual de Responsabilidade Limitada, seria de se esperar que os pequenos empreendimentos deixem de adotar a forma de sociedade limitada. Entretanto, na nova legislação há um forte incentivo para a pequena empresa continuar a adotar a forma de sociedade limitada.

Para constituir-se uma Eireli, há a exigência de que o capital social seja de cem salários mínimos, isto é, R \$ 54,5 mil em valores atuais. Este valor supera, em muito, o valor dos ativos empregados para a organização da maioria das pequenas empresas. Não é de se esperar, por exemplo, que o proprietário de um carrinho de cachorro quente empregue mais de cinquenta mil reais como capital social.

\footnotetext{
${ }^{73}$ Disponível em:

$<$ http://redir.stf.jus.br/estfvisualizadorpub/jsp/consultarprocessoeletronico/ConsultarProcessoEletr onico.jsf?seqobjetoincidente=4123688>. Acesso em: 25 mai. 2017.

${ }^{74}$ TRAVASSOS, 2015, p. 210-211.

${ }^{75}$ Disponível em:

$<$ http://www.camara.gov.br/proposicoesWeb/fichadetramitacao?idProposicao=522763>. Acesso em: 27 mai. 2017.
} 
O incentivo legislativo continua sendo voltado para a constituição de sociedades limitadas, em razão do fato de que não há exigência legal de valor mínimo para o capital social. Pode-se constituir uma sociedade limitada com um capital de, por exemplo, $\mathrm{R} \$ 3 \mathrm{mil}^{76}$.

Tal requisito contraria o propósito da norma que é estimular os pequenos negócios a se formarem. Tal propósito foi explicitado na justificativa do PL 2.730/2003, de autoria do deputado Almir Moura (PLRJ), que antecedeu na esteira histórica de apresentação de proposta de sociedade unipessoal o PL que deu origem à lei 12.441/2011:

A criação de sociedade unipessoal visa colocar sob o abrigo da proteção legal os comerciantes individuais, que não têm meios de constituir grandes empresas ou delas participar na qualidade de sócios. Com esta medida, facilita-se o estabelecimento de pequenos negócios, estimulando-se a economia do País ${ }^{77}$.

No que tange o segundo ponto, o Art. 7, IV da Carta Magna veda claramente a utilização do salário mínimo para fins de indexação, vide abaixo:

Art. $7^{\circ}$ São direitos dos trabalhadores urbanos e rurais, além de outros que visem à melhoria de sua condição social:

$[\ldots]$

IV - salário mínimo, fixado em lei, nacionalmente unificado, capaz de atender às suas necessidades vitais básicas e às de sua família com moradia, alimentação, educação, saúde, lazer, vestuário, higiene, transporte e previdência social, com reajustes periódicos que lhe preservem o poder aquisitivo, sendo vedada sua vinculação para qualquer fim;

Logo, determinar o capital social mínimo da EIRELI com base no salário mínimo é evidentemente inconstitucional. Esta inconstitucionalidade também foi aludida na petição inicial da já referida ADI 4.637/2011 e destacada no livro da Marcela Travassos:

\footnotetext{
${ }^{76}$ Disponível em:

<http://www.camara.gov.br/proposicoesWeb/prop_mostrarintegra?codteor=927285\&filename=PL +2468/2011>. Acesso em: 25 mai. 2017.

${ }^{77}$ Disponível em:

$<$ http://www.camara.gov.br/proposicoesWeb/prop_mostrarintegra?codteor=189037\&filename=PL +2730/2003>. Acesso em: 25 mai. 2017.
} 
O terceiro argumento apresentado pelo PPS na ADI 4.637/2011 refere-se à suposta inconstitucionalidade da vinculação do montante do capital social ao valor do salário mínimo, o que violaria o artigo $7^{\circ}, \mathrm{IV}$, da $\mathrm{CF}$, ressaltando que o 'salário mínimo não pode ser utilizado como critério de indexação para a determinação do capital mínimo necessário para a abertura de empresas individuais de responsabilidade limitada', de modo que 'tal exigência esbarra na notória vedação de vinculação do salário mínimo para qualquer fim, prevista no inciso IV do artigo $7^{\circ}$ da Constituição Federal ${ }^{78}$.

Rubens Requião também não considera o salário mínimo mero valor de referência e ressalta a inconstitucionalidade do salário mínimo como indexador:

[...] Note-se também a impropriedade de invocação do salário mínimo, que a Constituição reserva para designar como renda básica a ser paga ao empregado, sendo impossível servir como indexador ${ }^{79}$.

Diante do exposto, resta claro para mim não apenas que o capital social não deve ser constituído de acordo com o salário mínimo, mas combinando o primeiro ponto com o segundo aqui trazidos, não deveria haver requisito de capital mínimo algum, como não há para as sociedades limitadas.

Por fim, em relação ao terceiro ponto, o Art. 980-A, §2ª CC estabelece que "A pessoa natural que constituir empresa individual de responsabilidade limitada somente poderá figurar em uma única empresa dessa modalidade.". Ocorre que o Art.5 ${ }^{\circ}$, caput, da Constituição Federal ${ }^{80}$ consagra o princípio da isonomia ou igualdade no direito brasileiro. Deste modo, não se justifica tratamento desigual pela lei se não há diferença efetiva que enseje tal tratamento e esta é a crítica em questão. Falta aí fundamento efetivo para um tratamento diferenciado e maléfico às pessoas naturais, que deveriam ter o mesmo direito das pessoas jurídicas de constituírem diversos negócios por meio de EIRELI e, consequentemente, protegerem seus patrimônios pessoais. A justificativa do legislador é de que

\footnotetext{
78 TRAVASSOS, 2015, p. 211.

${ }^{79}$ REQUIÃO, 2012, p. 114.

${ }^{80}$ Art. $5^{\circ}$ Todos são iguais perante a lei, sem distinção de qualquer natureza, garantindo-se aos brasileiros e aos estrangeiros residentes no País a inviolabilidade do direito à vida, à liberdade, à igualdade, à segurança e à propriedade, nos termos seguintes:
} 
tal restrição existe para evitar abusos da limitação de responsabilidade e fraudes, o que não é suficiente para superar sua inconstitucionalidade. $\mathrm{O}$ trecho abaixo, destacado da obra da Marcela Quadra Travassos, esclarece essa questão:

Por mais que se tenha significativo avanço no tratamento do tema da limitação de responsabilidade do empresário individual por meio da EIRELI, ainda é possível notar certo preconceito do legislador quando se verifica a inconstitucional restrição a que pessoas naturais possam ser titulares de apenas uma EIRELI (cf. artigo 980-A, $\S 2^{\circ}$, do Código Civil).

Ao que parece, movido pela equivocada percepção de que a limitação de responsabilidade é um favor que se faz àquele que opta pelo exercício individual de atividade econômica, o legislador impôs inexplicável restrição à pessoa natural titular de EIRELI, no sentido de que somente possa figurar em uma sociedade desta natureza, enquanto que as pessoas jurídicas poderão ser titulares de várias EIRELIs sem restricão.

Ao restringir que pessoa natural somente possa ser titular de uma EIRELI tentou o legislador evitar que houvesse abuso irrestrito no uso da limitação de responsabilidade, vendo nestas estruturas potenciais riscos à prática de fraudes. Tal mecanismo de controle de abusos e fraudes, no entanto, vem gravado por insuperável inconstitucionalidade, ferindo a isonomia no tratamento do tema entre pessoas naturais e jurídicas, o que não se justifica. Entende-se eu o melhor seria que a pessoa natural pudesse constituir uma EIRELI para cada um de seus negócios, deixando a salvo o patrimônio relacionado a cada atividade específica como garantia dos credores diretamente vinculados àquela EIRELI, em alinhamento com a função promocional e transformadora que orienta o novo instituto ${ }^{81}$.

Destaco aqui trecho da obra de Pedro Lenza que conceitua o princípio da isonomia ao discutir hipótese de aplicação de sentença aditiva, definição que retrata perfeitamente o caso em questão, na medida que não há sentido em tratar pessoas naturais e jurídicas de forma distinta neste caso:

\footnotetext{
A sentença aditiva pode ser justificada, por exemplo, em razão da não observância do princípio da isonomia, notadamente nas situações em que a lei concede um certo benefício ou tratamento a determinadas pessoas, mas exclui outras que se enquadrariam na mesma situação ${ }^{82}$.
}

\footnotetext{
${ }^{81}$ TRAVASSOS, 2015, p. 285-286.

${ }^{82}$ LENZA, Pedro. Direito constitucional esquematizado. $16^{\mathrm{a}}$ ed. rev., atual. e ampl. São Paulo: Saraiva, 2012. p. 162.
} 
Isto posto, encerro este capítulo elogiando a boa vontade do legislador em criar uma figura jurídica que há muito era pleiteada pelos empresários individuais, contudo, reafirmo que a lei 12.441/2011, em sua imprecisão técnica, se mostrou em muitos fatores negativa aos seus maiores interessados, dificultando a atividade empresária. 


\section{CAPÍTULO 5 - MICROEMPRESA E EMPRESA DE PEQUENO PORTE}

\subsection{O Que São MEs e EPPs}

Diante do fato de que Empresários Individuais e Empresas Individuais de Responsabilidade Limitada podem ser classificadas como Microempresas e Empresas de Pequeno Porte, considerei por bem fazer breves considerações a respeito da matéria.

A classificação em Microempresa (ME) e Empresa de Pequeno Porte (EPP) é uma consagração constitucional expressa, por meio de seu Art.179, do princípio da isonomia tributária que "impõe a desigualdade de tratamento entre os sujeitos passivos que estejam em situação desigual, na medida das desigualdades entre eles havidas. ${ }^{83}$ :

Art. 179. A União, os Estados, o Distrito Federal e os Municípios dispensarão às microempresas e às empresas de pequeno porte, assim definidas em lei, tratamento jurídico diferenciado, visando a incentivá-las pela simplificação de suas obrigações administrativas, tributárias, previdenciárias e creditícias, ou pela eliminação ou redução destas por meio de lei.

Note que o artigo da Constituição Federal acima destacado estabelece que necessariamente esses conceitos serão definidos em lei apartada e para então cumprimento desse comando legal é editada a Lei Complementar 123/2006 (após leis anteriores em mesmo sentido) que estabelece regime diferenciado e favorecido às microempresas e empresas de pequeno porte:

Com fundamento na autorização constitucional, foi editada a Lei Complementar 123/2006, instituindo, conforme afirma seu primeiro artigo, 'normas gerais relativas ao tratamento diferenciado e favorecido a ser dispensado às microempresas e empresas de pequeno porte no âmbito dos Poderes da União, dos Estados, do Distrito Federal e dos Municípios' ${ }^{84}$.

\footnotetext{
${ }^{83}$ ALEXANDRE, 2016, p. 619-620.

${ }^{84}$ Ibid., p. 621.
} 
Assim, a lei estabelece faixas de receita bruta para determinar o enquadramento, sendo ME até $\mathrm{R} \$ 360.000,00$ e EPP superior a $\mathrm{R} \$$ $360.000,00$, mas inferior a $\mathrm{R} \$ 4.800 .000,00$ (valor de $\mathrm{R} \$ 3.600 .000,00$ até $1^{\circ}$ de janeiro de 2018 , novo valor fruto de alteração e vacatio legis pela LC 155/2016). Por receita bruta entende-se o produto da venda de bens e serviços nas operações de conta própria, o preço dos serviços prestados e o resultado nas operações em conta alheia, não incluídas as vendas canceladas e os descontos incondicionais concedidos. Depreende-se isto do Art. $3^{\circ}$, caput, da LC 123/2006 e seus incisos I, II e $\S 1^{\circ}$ :

Art. 3o Para os efeitos desta Lei Complementar, consideram-se microempresas ou empresas de pequeno porte, a sociedade empresária, a sociedade simples, a empresa individual de responsabilidade limitada e o empresário a que se refere $o$ art. 966 da Lei ${ }^{\circ}$ 10.406, de 10 de janeiro de 2002 (Código Civil), devidamente registrados no Registro de Empresas Mercantis ou no Registro Civil de Pessoas Jurídicas, conforme o caso, desde que:

I - no caso da microempresa, aufira, em cada ano-calendário, receita bruta igual ou inferior a $\mathrm{R} \$ 360.000,00$ (trezentos e sessenta mil reais); e

I- no-caso-da-mpresa de pequeno porte, aufira, em cada ano-calendário, receita bruta superior a R $\$ 360.000,00$ (trezentos e sessenta mil reais) e igual ou inferior a R\$ 3.600.000,00 (três milhões e seiscentes mil reais).

II - no caso de empresa de pequeno porte, aufira, em cada ano-calendário, receita bruta superior a $\mathrm{R} \$ 360.000,00$ (trezentos e sessenta mil reais) e igual ou inferior a $\mathrm{R} \$ 4.800 .000,00$ (quatro milhões e oitocentos mil reais). (Redação dada pela Lei Complementar no 155, de 2016) Produção de efeito

$\S 1$ - Considera-se receita bruta, para fins do disposto no caput deste artigo, o produto da venda de bens e serviços nas operações de conta própria, o preço dos serviços prestados e o resultado nas operações em conta alheia, não incluídas as vendas canceladas e os descontos incondicionais concedidos.

Tavares Borba trata de forma sintética dos benefícios conferidos pela lei às MEs e EPPs, como a dispensa de exigências documentais:

A Lei Complementar $n^{\circ} 123 / 06$, modificada pela Lei Complementar $n^{\circ} 139 / 11$,
simplificou, porém, no que tange a microempresas (receita anual de até $\mathrm{R} \$$
$360.000,00$ ) e empresas de pequeno porte (receita anual de até $\mathrm{R} \$$
$3.600 .000,00^{85}$ ), as exigências de natureza documental relativas a registro,

${ }^{85}$ Alterado para R \$ 4.800.000,00 pela Lei Complementar 155 de 27 de outubro de 2016, porém em vacatio legis até $1^{\circ}$ de janeiro de 2018. 
alteração ou baixa de empresa, além de conceder-lhes benefícios fiscais e procedimentais (substituição de assembleias e reuniões por deliberação majoritárias - art. 70; e dispensa de publicação de atos societários - art. 71) ${ }^{86}$.

Um dos principais benefícios é poder ser optante do Simples Nacional, que adveio da lei 9.317/1996 que instituía o Simples Federal Sistema Integrado de Pagamento de Impostos e Contribuições das Microempresas e Empresas de Pequeno Porte em Âmbito Federal - e foi revogado após a LC 123/2006. O Simples Nacional surgiu então com a Emenda Constitucional 42 de 19 de dezembro de 2003 que incluiu a alínea $d$ ao inciso III do Art. 146 da Constituição Federal e facultou, ainda, em seu parágrafo único, a criação pelo poder público de regime único de arrecadação dos impostos e contribuições da União, dos Estados, do Distrito Federal e dos Municípios:

Art. 146. Cabe à lei complementar:

III - estabelecer normas gerais em matéria de legislação tributária, especialmente sobre:

a) definição de tributos e de suas espécies, bem como, em relação aos impostos discriminados nesta Constituição, a dos respectivos fatos geradores, bases de cálculo e contribuintes;

b) obrigação, lançamento, crédito, prescrição e decadência tributários;

c) adequado tratamento tributário ao ato cooperativo praticado pelas sociedades cooperativas.

d) definição de tratamento diferenciado e favorecido para as microempresas e para as empresas de pequeno porte, inclusive regimes especiais ou simplificados no caso do imposto previsto no art. 155, II, das contribuições previstas no art. 195, I e $\$ \S 12$ e 13, e da contribuição a que se refere o art. 239. (Incluído pela Emenda Constitucional n ${ }^{\circ} 42$, de 19.12.2003);

Parágrafo único. A lei complementar de que trata o inciso III, d, também poderá instituir um regime único de arrecadação dos impostos e contribuições da União, dos Estados, do Distrito Federal e dos Municípios, observado que: (Incluído pela Emenda Constitucional no 42, de 19.12.2003);

${ }^{86}$ BORBA, 2012, p. 21-22. 
I - será opcional para o contribuinte; (Incluído pela Emenda Constitucional n ${ }^{\circ} 42$, de 19.12.2003);

II - poderão ser estabelecidas condições de enquadramento diferenciadas por Estado; (Incluído pela Emenda Constitucional nº 42, de 19.12.2003);

III - o recolhimento será unificado e centralizado e a distribuição da parcela de recursos pertencentes aos respectivos entes federados será imediata, vedada qualquer retenção ou condicionamento; (Incluído pela Emenda Constitucional $\mathrm{n}^{\mathrm{o}}$ 42, de 19.12.2003);

IV - a arrecadação, a fiscalização e a cobrança poderão ser compartilhadas pelos entes federados, adotado cadastro nacional único de contribuintes. (Incluído pela Emenda Constitucional n ${ }^{\circ} 42$, de 19.12.2003).

Logo vê-se que ME e EPP são de grande vantagem às empresas.

\subsection{Crítica aos Institutos da ME e EPP}

Pelos motivos expostos no subcapítulo acima, minhas críticas em relação à ME e EPP não se tratam - assim como não se tratavam nos outros institutos - de críticas à sua razão de existir, mas sim a pontos específicos que podem ser aprimorados. Ressalto aqui que como o EI e a EIRELI podem se enquadrar como ME e EPP, é importante se ter em mente que críticas nesse subcapítulo podem ter correlação ou se aplicar aos outros dois institutos (quando enquadrados).

Aqui aponto, então, a minha discordância: (i) quanto à proporcionalidade de receitas mensais ao ingressar nos regimes em questão no próprio ano calendário (situação similar à MEI); (ii) efeitos retroativos por receita superior à $20 \%$ da proporcionalidade mensal em caso de ingresso no próprio ano calendário; e (iii) quanto à obrigatoriedade de deter contabilidade.

No que diz respeito ao primeiro ponto, trago para cá as críticas já construídas quanto ao MEI, porém em montantes diferentes, explico. $\mathrm{O} \S 2^{\circ}$ do Art. $3^{\circ}$ da Lei 123/2006 estabelece que em caso de início de atividade no próprio ano-calendário, o limite a que se refere o caput do artigo $3^{\circ}$ (vide 
subcapítulo anterior para leitura do artigo) será proporcional ao número de meses em que a ME ou a EPP houver exercido atividade, inclusive as frações de meses:

$\S 2^{\circ}$ No caso de início de atividade no próprio ano-calendário, o limite a que se refere o caput deste artigo será proporcional ao número de meses em que a microempresa ou a empresa de pequeno porte houver exercido atividade, inclusive as frações de meses.

Discordo dessa opção do legislador, uma vez que determinadas empresas possuem renda mensal extremamente variável, logo, se a empresa tiver iniciado suas atividades em meses atípicos de bom movimento pode acabar por desenquadrada. O tributarista Ricardo Alexandre clarifica a disposição legal:

Assim, se uma empresa iniciar suas atividades em setembro de 2012 e quiser se enquadrar à sistemática na condição de empresa de pequeno porte não poderá auferir, até o final do ano-calendário, receita bruta superior a $\mathrm{R} \$ 1.200 .000,00$.

O valor é obtido pela multiplicação de $\mathrm{R} \$ 300.000,00$ (valor proporcional a um mês do teto estipulado para as EPP - R \$ 3.600.000,00 anuais) pela quantidade de meses restantes para o final do exercício (no exemplo, quatro meses). Assim, R\$ $300.000,00 \times 4=\mathrm{R} \$ 1.200 .000,00^{87}$.

Aproveito então o ensejo para tratar do segundo ponto, situação também similar à MEI, conforme tratado anteriormente: a retroatividade consequente do desenquadramento por valor superior a $20 \%$ do limite legal. Também não me estenderei porque esse ponto já foi contraditado na temática do MEI, então só faço um paralelo considerando os parágrafos $10^{\circ}$ e $12^{\circ}$ do artigo $3^{\circ}$ da LC 123/2006 que são aplicáveis a ME e EPP (vide parágrafos destacados abaixo), haja vista que deixei claro quanto ao MEI que não concordo com esta espécie de disposição legal pelo caráter punitivo e inconstitucional - em violação ao Art. 174, CF - que parece carregar.

$\S 10$. A empresa de pequeno porte que no decurso do ano-calendário de início de atividade ultrapassar o limite proporcional de receita bruta de que trata o § 20 estará excluída do tratamento jurídico diferenciado previsto nesta Lei Complementar, bem como do regime de que trata o art. 12 desta Lei Complementar, com efeitos retroativos ao início de suas atividades.

\footnotetext{
${ }^{87}$ ALEXANDRE, 2016, p. 622.
} 
$\S 12$. A exclusão de que trata $\mathrm{o} \S \mathbf{1 0}$ não retroagirá ao início das atividades se o excesso verificado em relação à receita bruta não for superior a $20 \%$ (vinte por cento) do respectivo limite referido naquele parágrafo, hipótese em que os efeitos da exclusão dar-se-ão no ano-calendário subsequente.

A respeito dessa questão é importante salientar que o tributarista Ricardo Alexandre critica esse possível caráter punitivo da norma ao se estabelecer retroatividade em caso de lucro superior ao limite legal, mas apenas em se tratando de ocorrência no ano seguinte ao ano calendário em que as atividades se iniciaram. Vide abaixo a explicação do cálculo da disposição legal e em seguida sua observação acerca da dita punição ao lucro:

A empresa de pequeno porte que, no decurso do ano-calendário de início de atividade, ultrapassar o limite de $\mathrm{R} \$ 300.000,00$ multiplicados pelo número de meses de funcionamento nesse período estará excluída do Simples Nacional, com efeitos retroativos ao início das atividades. Somente deixará de haver retroatividade se o excesso não for superior a $20 \%$ do limite legalmente estabelecido.

Assim, se no ano-calendário de início de atividade a empresa obtiver uma receita superior a $\mathrm{R} \$ 300.000,00$ multiplicados pelo número de meses de funcionamento nesse período, mas não superior a $\mathrm{R} \$ 360.000,00$ multiplicados por este mesmo número de meses (R \$ 300.000,00 acrescidos de 20\%), a exclusão ocorrerá, mas sem efeitos retroativos. Caso ultrapassado este segundo limite, a retroatividade se impõe.

No caso de retroatividade, a microempresa ou a empresa de pequeno porte desenquadrada ficará sujeita ao pagamento da totalidade ou diferença dos respectivos impostos e contribuições, devidos de conformidade com as normas gerais de incidência, acrescidos, tão somente, de juros de mora, quando efetuados antes do início de procedimento de ofício. Faculta-se à entidade excluída a opção pelo recolhimento do imposto de renda e da Contribuição Social sobre o Lucro Líquido na forma do lucro presumido ou do lucro real trimestral ou anual.

Pela redação originária da LC 123/2006, caso o excesso não ocorresse no anocalendário de início de atividade, a exclusão se verificaria sem efeito retroativo, somente sujeitando a entidade excluída ao recolhimento individualizado dos tributos a partir do ano-calendário subsequente. Com o advento da LC 139/2011, a exclusão passa a ocorrer já no mês seguinte, salvo se o excesso verificado em relação à receita bruta não for superior a $20 \%$, hipótese em que os efeitos da exclusão permanecem se confirmados apenas a partir do ano-calendário subsequente (LC 123/2006, art. 3..$^{\circ}$ §§ 9. ${ }^{\circ}$ e $\left.9 .^{\circ}-A\right)$. De qualquer forma, mantém-se afastada a retroatividade, evitando-se uma verdadeira 
punição para a empresa que "cresceu" e deixou a condição de empresa de pequeno porte, algo que é desejável em uma economia capitalista ${ }^{88}$.

A última crítica, ponto (iii), gira em torno da obrigatoriedade de MEs e EPPs seguirem um sistema de contabilidade, mecanizado ou não, com base na escrituração uniforme de seus livros, em correspondência com a documentação respectiva, e a levantar anualmente o balanço patrimonial e o de resultado econômico, conforme dispõe o Art. 1.179, $\mathrm{CC}^{89}$. Tal exigência é criticável na medida em que a Constituição, em seu Art. 179, já mencionado em ocasião anterior neste trabalho, prevê que deve haver tratamento diferenciado às MEs e EPPs e simplificação de suas obrigações:

Art. 179. A União, os Estados, o Distrito Federal e os Municípios dispensarão às microempresas e às empresas de pequeno porte, assim definidas em lei, tratamento jurídico diferenciado, visando a incentivá-las pela simplificação de suas obrigações administrativas, tributárias, previdenciárias e creditícias, ou pela eliminação ou redução destas por meio de lei.

Estabelece então o Art. 146, III, $d$, CF que o tratamento diferenciado às MEs e EPPs se dará por meio de lei complementar:

Art. 146. Cabe à lei complementar:

$[\ldots]$

III - estabelecer normas gerais em matéria de legislação tributária, especialmente sobre:

$[\ldots]$

d) definição de tratamento diferenciado e favorecido para as microempresas e para as empresas de pequeno porte, inclusive regimes especiais ou simplificados no caso do imposto previsto no art. 155, II, das contribuições previstas no art. 195, I e $\S \S 12$ e 13, e da contribuição a que se refere o art. 239. (Incluído pela Emenda Constitucional no 42, de 19.12.2003).

No entanto, o Art. 1.179, CC estabelece as obrigações contábeis do empresário e da sociedade:

\footnotetext{
${ }^{88}$ ALEXANDRE, 2016, p. 622-623.

89 Art. 1.179. O empresário e a sociedade empresária são obrigados a seguir um sistema de contabilidade, mecanizado ou não, com base na escrituração uniforme de seus livros, em correspondência com a documentação respectiva, e a levantar anualmente o balanço patrimonial e o de resultado econômico.
} 
Art. 1.179. O empresário e a sociedade empresária são obrigados a seguir um sistema de contabilidade, mecanizado ou não, com base na escrituração uniforme de seus livros, em correspondência com a documentação respectiva, e a levantar anualmente o balanço patrimonial e o de resultado econômico.

$\S 1^{\circ}$ Salvo o disposto no art. 1.180, o número e a espécie de livros ficam a critério dos interessados.

§ 2o É dispensado das exigências deste artigo o pequeno empresário a que se refere 0 art. 970.

E em seu $§ 2^{\circ}$ (acima destacado) dispensa dessas obrigações apenas o pequeno empresário e define que o "pequeno empresário" referido é aquele que consta do Art. 970, CC:

Art. 970. A lei assegurará tratamento favorecido, diferenciado e simplificado ao empresário rural e ao pequeno empresário, quanto à inscrição e aos efeitos daí decorrentes.

O Art. 970, CC, por sua vez, como é perceptível da leitura do artigo acima, não define quem é o pequeno empresário, que só no Art. 68 da LC 123/2006 vem a ser indicado guiando a uma definição:

Art. 68. Considera-se pequeno empresário, para efeito de aplicação do disposto nos arts. 970 e 1.179 da Lei no 10.406, de 10 de janeiro de 2002 (Código Civil), o empresário individual caracterizado como microempresa na forma desta Lei Complementar que aufira receita bruta anual até o limite previsto no $\S 1^{\circ}$ do art. 18-A.

O Art. 68 da LC 123/2006 finalmente faz referência a artigo que dá uma definição para microempresário: Art. 18-A, $\S 1^{\circ}$ da LC $123 / 2006^{90}$ (vide abaixo). Todavia, este último artigo traz uma resposta insatisfatória para a questão porque limita o conceito de micro empresário ao empresário individual ou o empreendedor que exerça as atividades de industrialização, comercialização e prestação de serviços no âmbito rural, que tenha auferido receita bruta, no ano-calendário anterior, de até $\mathrm{R} \$ 81.000,00$, quando, em verdade, pela disposição constitucional vista anteriormente - Art. 179, CF a simplificação de exigências possui sentido amplo e deveria atingir às

90 Disponível em: <http://www.portaldecontabilidade.com.br/tematicas/MEIcontabilidade.htm>. Acesso em: 27 mai. 2017. 
microempresas e empresas de pequeno porte como um todo. Invoca-se aqui, novamente, o princípio da isonomia.

Art. 18-A. O Microempreendedor Individual - MEI poderá optar pelo recolhimento dos impostos e contribuições abrangidos pelo Simples Nacional em valores fixos mensais, independentemente da receita bruta por ele auferida no mês, na forma prevista neste artigo.

§ 1o Para os efeitos desta Lei Complementar, considera-se MEI o-mpresário individual a que se refere 0 art. 966 da Lei no 10.406 , de 10 de janeiro de 2002 (Código Civil), que tenha auferido receita bruta, no ano-calendário anterior, de até R\$ $60.000,00$ (sessenta mil reais), optante pelo-Simples Nacional e que não esteja impedido de optar pela sistemática prevista neste artigo.

§ 1o Para os efeitos desta Lei Complementar, considera-se MEI o empresário individual que se enquadre na definição do art. 966 da Lei $n^{\circ} 10.406$, de 10 de janeiro de 2002 - Código Civil, ou o empreendedor que exerça as atividades de industrialização, comercialização e prestação de serviços no âmbito rural, que tenha auferido receita bruta, no ano-calendário anterior, de até $\mathbf{R} \$ \mathbf{8 1 . 0 0 0 , 0 0}$ (oitenta e um mil reais), que seja optante pelo Simples Nacional e que não esteja impedido de optar pela sistemática prevista neste artigo. (Redação dada pela Lei Complementar $n^{\circ}$ 155, de 2016) Produção de efeito.

Tavares Borba também é claro ao criticar esta questão e demonstrar descontentamento com a opção do legislador:

O art. 970 do Código Civil transfere à lei (outra lei) a forma de assegurar à pequena empresa um 'tratamento favorecido, diferenciado e simplificado quanto à inscrição e aos efeitos daí decorrentes.

A Lei Complementar $n^{\circ}$ 123/06, modificada pela Lei Complementar $n^{\circ}$ 139/2011, disciplinou a matéria, de forma específica, preceituando (art. 68) que, para os efeitos dos art. 970 e 1.179 do Código Civil, pequeno empresário seria apenas o empresário individual, caracterizado como microempresa, e que auferisse receita bruta anual não superior a $\mathrm{R} \$ 60.000,00^{91}$. O conceito foi, portanto, restringido a profissionais com receita irrisória, e, por isso mesmo, incapazes de suportar uma organização empresarial. Esvaziou-se, em consequência, o escopo do art. 970 do Código Civil ${ }^{92}$.

Conclui-se, portanto, que apesar da ME e EPP serem classificações benéficas ao empresário ou sociedade, requerem aperfeiçoamentos importantes para que cumpram genuinamente sua função motriz simplificadora.

\footnotetext{
${ }^{91}$ Valor alterado para R $\$ 81.000,00$ pela LC 155/2016 em vacatio legis até $1^{\circ}$ de janeiro de 2018.

${ }^{92}$ BORBA, 2012, p. 21.
} 


\section{CONCLUSÃO}

Diante do exposto, resta claro que a falta de limitação de responsabilidade dos Empresários Individuais é ainda um gargalo em nosso ordenamento e a criação da EIRELI como solução para essa questão foi louvável, porém ainda não suficiente. Além disso, evidenciou-se que os institutos do MEI, da ME e da EPP ainda requerem melhorias.

Reforço que não posso me furtar a dizer que todos os institutos aqui tratados representam grande avanço, visando estimular uma certa eficiência e um dinamismo do mercado, além de retirar profissionais da informalidade. Todavia, foram desenvolvidos sem a reflexão profunda necessária e, portanto, ainda estão aquém de efetivamente propiciar um ambiente favorável ao empreendedorismo. Por esse motivo, o presente trabalho buscou apresentar uma visão crítica acerca desses institutos tão essenciais ao dia-a-dia empresarial, porém inadequados em grande medida, e demonstrar que os empecilhos jurídicos aqui abordados não se limitam aos empresários, mas afetam toda a sociedade de forma sistêmica.

Expôs-se aqui uma fração dos entraves que enfrentam os Autônomos e que não precisariam existir, uma vez que ao se dificultar o surgimento e o crescimento de negócios prejudica-se a economia brasileira, reduzindo a geração de empregos, renda e a arrecadação de tributos. Demonstra-se, portanto, a necessidade do aprimoramento legal dos institutos aqui trazidos. Enfatizo, contudo, que existem inúmeros outros fatores, principalmente procedimentais, aqui não mencionados, que precisam ser extintos ou alterados.

Não obstante as limitações do presente trabalho, diante da miríade de críticas que poderiam ser tecidas, afirmo que precisamos de uma reforma legal da figura jurídica do 'empresário individual de responsabilidade limitada' ou da sociedade unipessoal. Conforme se demonstrou, ao empresário individual deve ser conferida personalidade jurídica e a 
possibilidade de tratamento tributário simplificado, razoável e proporcional aos seus lucros, no desempenho de qualquer atividade empresária, sem rol taxativo em lista, e sem requisito de capital social mínimo.

Uma alteração de leis também se faria essencial para se extirpar do ordenamento obrigações acessórias desnecessárias que não cumprem com a sua finalidade, seja educativa ou fiscalizatória, como o requisito de relatórios mensais para MEI e a necessidade de manutenção de registro de livros contábeis por ME e EPP. Ou mesmo o absurdo da declaração de imposto de renda, que é obrigação tributária recorrente de todos que auferem renda, logo, deveria ser simples, entretanto, apresenta procedimentos excessivamente complexos. Por exemplo, no contexto atual, é impossível para um MEI elaborar sua declaração de IRPF sem o auxílio de um contador, o que impõe mais um encargo aos empreendedores brasileiros. Como consta da Figura $2^{93}$ (Página 12), 1,5\% do faturamento das empresas no Brasil é gasto no cumprimento de obrigações acessórias. Assim, é necessário que se refreie um Estado inchado e ineficiente, que o é em grande medida por exigências infundadas ou retrógradas.

Acrescento que precisamos de leis que permitam a manutenção de regimes tributários que estimulem o crescimento das pequenas empresas. De modo ilustrativo, seria necessária uma reforma legal para que quando iniciadas atividades empresárias na condição de MEI, ME ou EPP após o início do ano calendário, a definição do limite de faturamento para desenquadramento se baseasse no rendimento anual das empresas e não na distribuição proporcional mensal. E ainda que o desenquadramento se mantivesse tendo por base a proporção mensal, jamais se poderia considerar a retroatividade tributária. $\mathrm{O}$ lucro deve ser estimulado e não o contrário.

Vale dizer ainda que a escolha do tema em questão adveio da minha paixão pelo empreendedorismo e da crença de que a facilitação de processos, procedimentos e de que o descomplicar de institutos é

93 Disponível em: <https://www.superempreendedores.com/web/infograficos/custo-brasil-aincrivel-carga-tributaria-brasileira/>. Acesso em: 19 mai. 2017. 
indispensável para criação de um ambiente fértil para o crescimento econômico. Em verdade, apesar deste assunto ser pouco tratado, não deve ser menosprezado, afinal, os pequenos negócios são a semente das grandes empresas.

Logo, conclui-se que o ideal seria que os pequenos empresários pudessem se valer de uma legislação mais flexível, para que esse momento atual de crise vivido pelo Brasil seja visto pelos empresários e investidores como uma oportunidade e não como um problema insuperável. O Brasil precisa, talvez mais do que nunca, do fomento ao empreendedorismo, que atualmente é uma opção não só dos empreendedores natos, amantes do risco, mas também uma alternativa quase que obrigatória para os desempregados que não encontram espaço no mercado de trabalho. Isso é fator crucial não só para a superação da crise, mas para o verdadeiro crescimento da nação verde amarela, o que a alçará, um dia, ao status de 'desenvolvida'. 


\section{REFERÊNCIAS BIBLIOGRÁFICAS}

AGU. Manifestação ADI no 4.637/2011. p. 2. Disponível em:

<www.agu.gov.br/page/download/index/id/9460565>. Acesso em: 18 mai. 2017.

ALEXANDRE, Ricardo. Direito tributário esquematizado. $10^{\mathrm{a}}$ ed. rev., atual. e ampl. Rio de Janeiro: Forense; São Paulo: MÉTODO, 2016.

BORBA, José Edwaldo Tavares. Direito societário. $13^{\mathrm{a}}$ ed. ver. e atual. Rio de Janeiro: Renovar, 2012.

BRASIL. Lei ${ }^{\circ} 10.406$, de 10 de janeiro de 2002. Código Civil. Disponível em: <http://www.planalto.gov.br/ccivil_03/leis/2002/L10406.htm>. Acesso em: 27 mai. 2017.

CORDEIRO, Adolpho Touzon D. et al. Contratação e pagamento por empresa no exterior; estrutura societária e tributária mais vantajosa. Parecer Técnico. ESCRITÓRIO TOUZON, CASEMIRO, BATALHA \& AZEVEDO ADVOGADOS. Ago. 2016. 7 p.

DELGADO, Mauricio Godinho. Curso de direito do trabalho. $11^{\mathrm{a}}$ ed. São Paulo: LTr, 2012.

Disponível em: <http://drei.smpe.gov.br/documentos/00-ranking-janeiro-adezembro2016.pdf>. Acesso em: 19 mai. 2017.

Disponível em: <http://epocanegocios.globo.com/colunas/Financas-deBolso/noticia/2017/03/ir-2017-quem-e-mei-precisa-declarar-ir-em-algumassituacoes-sim.html>. Acesso em: 16 mai. 2017.

Disponível em: <http://especiais.g1.globo.com/economia/2016/quando-obrasil-vai-sair-da-recessao/>. Disponível em: 19 mai. 2017.

Disponível em: <http://www.empresometro.com.br/Site/Estatisticas>. Acesso em: 22 mar. 2017.

Disponível em: <http://www.ltr.com.br/loja/folheie/4996.pdf>. Acesso em: 10 mai. 2017. 
Disponível em: <http://www.oabsp.org.br/noticias/2016/01/apos-longabatalha-figura-da-sociedade-unipessoal-e-criada-no-pais.10596>. Acesso em: 15 mai. 2017.

Disponível em: <http://www.portaldoempreendedor.gov.br/empresarioindividual $>$. Acesso em: 22 mar. 2017.

Disponível em: <http://www.portaldoempreendedor.gov.br/legislacao/leise-decretos>. Acesso em: 22 mar. 2017.

Disponível em: <http://www.portaldoempreendedor.gov.br/perguntasfrequentes/duvidas-relacionadas-ao-microempreendedor-individual-1/3formalizacao-como-mei>. Acesso em: 16 mai. 2017.

Disponível em: <http://www.portaldoempreendedor.gov.br/perguntasfrequentes/duvidas-relacionadas-ao-microempreendedor-individual-1/132013-outros-assuntos〉. Acesso em: 16 mai. 2017.

Disponível em: <http://www25.senado.leg.br/web/atividade/materias//materia/87005>. Acesso em: 16 mai. 2017.

Disponível em: <https://economia.terra.com.br/vida-de-empresario/18-dosmunicipios-concentram-metade-das-empresas-dobrasil,c19bc20ce10b6410VgnVCM20000099cceb0aRCRD.html>. Acesso em: 22 mar. 2017.

Disponível em: <https://jus.com.br/artigos/20993/a-empresa-individual-deresponsabilidade-limitada-aspectos-societarios-tributarios-e-economicos>. Acesso em: 22 mar. 2017.

Disponível em: <https://www.jornalcontabil.com.br/conheca-diferencasentre-mei-ei-e-eireli-para-abrir-uma-empresa-sem-socio/>. Acesso em: 14 mai. 2017.

Disponível em: <https://www.qualtrics.com/>. Acesso em: 25 mai. 2017.

Disponível em: <https://www12.senado.leg.br/manualdecomunicacao/guiade-economia>. Acesso em: 23 mai. 2017.

Disponível em: <www.camara.gov.br/sileg/integras/793401.pdf>. Acesso em: 27 mai. 2017.

Disponível em: <http://dinheirama.com/blog/2016/01/20/impactosoperacao-lava-jato-economia-brasileira/>. Acesso em: 20 mai. 2017. 
Disponível em: <http://drei.smpe.gov.br/legislacao/instrucoesnormativas/titulo-menu/pasta-instrucoes-normativas-em-vigor-04/in-102013-anexo-1-manual-de-registro-de-empresario-individual-08-092014.pdf>. Acesso em: 22 mar. 2017.

Disponível em:

$\langle$ http://m.law.uchicago.edu/files/files/53.Posner.Values_0.pdf $>$. Acesso em: 24 mai. 2017.

Disponível em:

<http://redir.stf.jus.br/estfvisualizadorpub/jsp/consultarprocessoeletronico/ ConsultarProcessoEletronico.jsf? seqobjetoincidente $=4123688>$. Acesso em: 25 mai. 2017.

Disponível em:

<http://www.ambitojuridico.com.br/site/?n_link=revista_artigos_leitura\&ar tigo_id=11744>. Acesso em: 17 mai. 2017.

Disponível em:

$\langle$ http://www.biblioteca.pucminas.br/teses/Direito_PortoLV_1.pdf $>$. Acesso em: 16 mai. 2017.

Disponível em:

<http://www.camara.gov.br/proposicoesWeb/fichadetramitacao?idProposic ao=522763>. Acesso em: 27 mai. 2017.

Disponível em:

<http://www.camara.gov.br/proposicoesWeb/prop_mostrarintegra;jsessioni d=9F3DDED233B958F9694BCA9BFC101710.proposicoesWebExterno1? codteor=631421\&filename=PL+4605/2009> . Acesso em: 25 mai. 2017.

Disponível em:

<http://www.camara.gov.br/proposicoesWeb/prop_mostrarintegra?codteor= 927285\&filename $=$ PL+2468/2011 >. Acesso em: 25 mai. 2017.

Disponível em:

<http://www.camara.gov.br/proposicoesWeb/prop_mostrarintegra?codteor= 189037\&filename=PL+2730/2003>. Acesso em: 25 mai. 2017.

Disponível em:

<http://www.fazenda.rj.gov.br/sefaz/ShowProperty?nodeId=\%2FUCMServ er\%2FWCC312673>. Acesso em: 22 mar. 2017. 
Disponível em:

<http://www.institucional.jucesp.sp.gov.br/institucional_noticias_isenta.php $>$. Acesso em: 14 mai. 2017.

Disponível em:

<http://www.lex.com.br/doutrina_26983953_A_SOCIEDADE_UNIPESSO AL_NO_DIREITO_BRASILEIRO.aspx>. Acesso em: 15 mai. 2017.

Disponível em: <http://www.planalto.gov.br/ccivil_03/_ato20112014/2011/Exm/EMI-13-MF-MDIC-MPS-Mpv529.htm>. Acesso em: 16 mai. 2017.

Disponível em: <http://www.planalto.gov.br/ccivil_03/_ato20112014/2011/lei/112441.htm>. Acesso em: 19 mai. 2017.

Disponível em:

<http://www.planalto.gov.br/ccivil_03/leis/LCP/Lcp123.htm>. Acesso em: 27 mai. 2017.

Disponível em:

<http://www.portaldecontabilidade.com.br/tematicas/MEIcontabilidade.htm >. Acesso em: 27 mai. 2017.

Disponível em:

<http://www.portaldoempreendedor.gov.br/legislacao/resolucoes/arquivos/ ANEXO_XIII.pdf>. Acesso em: 16 mai. 2017.

Disponível em: <http://www.portaldoempreendedor.gov.br/perguntasfrequentes/duvidas-relacionadas-ao-microempreendedorindividual/impostos-das-nota-fiscal/o-microempreendedor-individual-devepagar-imposto-de-renda-pessoa-fisica-irpf> . Acesso em: 16 mai. 2017.

Disponível em:

<http://www.rio.rj.gov.br/dlstatic/10112/2904248/4104508/guia_orientador .pdf>. Acesso em: 22 mai. 2017.

Disponível em: <http://www.valor.com.br/brasil/4824392/pedidos-derecuperacao-judicial-batem-recorde-em-2016-nota-serasa >. Disponível em: 20 mai. 2017.

Disponível em: <https://economia.uol.com.br/imposto-derenda/noticias/redacao/2016/03/26/ir-2016-microempreendedor-individualsempre-precisa-declarar-imposto.htm>. Acesso em: 16 mai. 2017. 
Disponível em:

<https://idg.receita.fazenda.gov.br/interface/cidadao/irpf/2017/apresentacao /obrigatoriedade>. Acesso em: 16 mai. 2017.

Disponível em: <https://www.jucees.es.gov.br/empresario-individualconstituicao/>. Acesso em: 11 mai. 2017.

Disponível em:

$<$ https://www.sebrae.com.br/sites/PortalSebrae/artigos/entenda-o-que-euma-eireli,4fe2be300704e410VgnVCM1000003b74010aRCRD>. Acesso em: 16 mai. 2017.

Disponível em:

<https://www.sebrae.com.br/sites/PortalSebrae/ufs/ms/artigos/serie-meipasso-a-passo-para-elaboracao-do-relatorio-

mensal,a0a12bb750c04510VgnVCM1000004c00210aRCRD>. Acesso em: 16 mai. 2017.

Disponível em:

<https://www.superempreendedores.com/web/infograficos/custo-brasil-aincrivel-carga-tributaria-brasileira/> . Acesso em: 19 mai. 2017.

FIESP. Relatório Burocracia: custos econômicos e propostas de combate. Equipe Técnica. Junho de 2010. Disponível em:

$<$ http://www.fiesp.com.br/indices-pesquisas-e-publicacoes/relatorioburocracia-custos-economicos-e-propostas-de-combate/>. Acesso em: 24 mai. 2017.

Disponível em:

<http://normas.receita.fazenda.gov.br/sijut2consulta/link.action?idAto=368 33\&visao=anotado $>$. Acesso em: 25 mai. 2017.

LENZA, Pedro. Direito constitucional esquematizado. $16^{\mathrm{a}}$ ed. rev., atual. e ampl. São Paulo: Saraiva, 2012.

RAMOS, André Luiz Santa Cruz. Direito empresarial esquematizado. $6^{\mathrm{a}}$ ed. rev. atual. e ampl. Rio de Janeiro: Forense; São Paulo: MÉTODO, 2016.

RECEITA FEDERAL DO BRASIL - RFB. Resolução CGSN nº 94, de 29 de novembro de 2011. (Publicado(a) no DOU de 01/12/2011, seção , pág. 50). Disponível em:

$<$ http://normas.receita.fazenda.gov.br/sijut2consulta/link.action?idAto=368 33\&visao=anotado $>$. Acesso em: 25 mai. 2017. 
REQUIÃO, Rubens Edmundo. Curso de Direito Comercial. $31^{\mathrm{a}}$. ed. rev. E atual. $1^{\circ}$ v. São Paulo: Saraiva, 2012.

SEBRAE. Valor adicionado das Micro e Pequenas Empresas na Economia Nacional 2009 a 2011. Disponível em:

<https://www.sebrae.com.br/Sebrae/Portal\%20Sebrae/Estudos\%20e\%20Pe squisas/Participacao\%20das $\% 20 \mathrm{micro} \% 20 \mathrm{e} \% 20$ pequenas $\% 20 \mathrm{empresas}$.pdf >. Acesso em: 16 mai. 2017.

Somatório dos dados. Disponível em:

<http://drei.smpe.gov.br/assuntos/estatisticas/relatorio-mensal>. Acesso em: 19 mai. 2017.

TRAVASSOS, Marcela Maffei Quadra. Empresa individual de responsabilidade limitada (EIRELI): análise constitucional do instituto, unipessoalidade e mecanismos de controle de abusos e fraudes. Rio de Janeiro: Renovar, 2015. 